U.S. DEPARTMENT OF THE INTERIOR

U.S. GEOLOGICAL SURVEY

\title{
REPORT ON SEISMOLOGIC FIELD INVESTIGATIONS \\ OF THE 29 JUNE 1992 \\ LITTLE SKULL MOUNTAIN EARTHQUAKE
}

by

M. Meremonte, E. Cranswick, J. Gomberg,

D. Worley,D. Carver, J. Brooks, 1

R. Banfill, 2

D. Overturf, and T. Bice 1

Open-File Report 93-555

This report is preliminary and has not been reviewed for conformity with U.S. Geological Survey editorial standards and stratigraphic nomenclature. Any use of trade, product, or firm names is for descriptive purposes only and does not imply endorsement by the USGS.

1 Golden, CO

2 Small Systems Support

2 Boston Harbor Place

Big Water, UT 84741-0205 


\section{Contents}

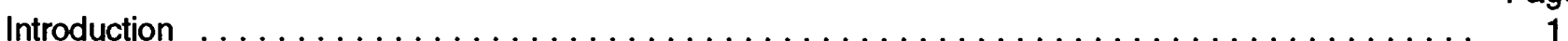

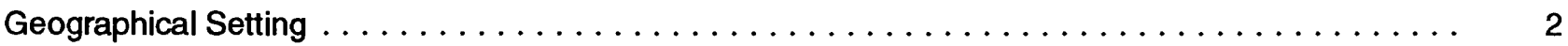

Description of the Instrumentation $\ldots \ldots \ldots \ldots \ldots \ldots \ldots \ldots \ldots \ldots \ldots \ldots \ldots \ldots \ldots$

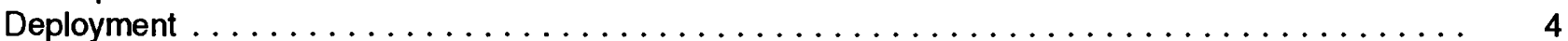

Clock Corrections $\ldots \ldots \ldots \ldots \ldots \ldots \ldots \ldots \ldots \ldots \ldots \ldots \ldots \ldots \ldots \ldots \ldots \ldots$

Field Operation and Processing $\ldots \ldots \ldots \ldots \ldots \ldots \ldots \ldots \ldots \ldots \ldots \ldots \ldots \ldots \ldots$

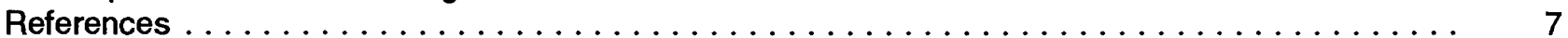

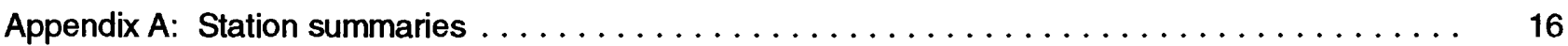

Appendix B: Clock summary of the master clock instruments . . . . . . . . . . . . . . . 49

Appendix C: Copy of the tape labels (field logs) for DR200 instruments . . . . . . . . . . . 53

Appendix D: Photographs of the station installations $\ldots \ldots \ldots \ldots \ldots \ldots \ldots \ldots \ldots \ldots \ldots$

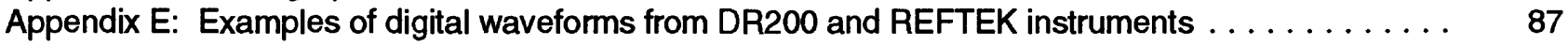

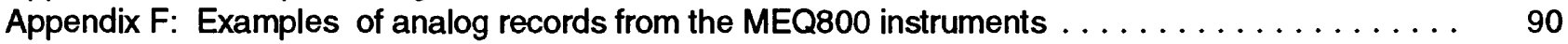

\section{Tables}

Table 1. Summmary of earthquakes in the southern Great Basin $\geq M_{L}=5.0$ within $150 \mathrm{~km}$ of the proposed

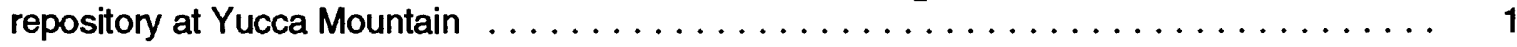

Table 2. List of earthquakes $\geq M_{L}=2.5$ within $50 \mathrm{~km}$ of the proposed repository at Yucca Mountain . . 1

Table 3. List of the major geologic structures surrounding Little Skull Mountain . . . . . . . . . . 3

Table 4. Summary list of the names, recorder types (digital or analog), general geographic locations, coordinate locations and elevations of the USGS portable stations deployed . . . . . . . 5

\section{Illustrations}

Figure 1. Map showing the southern Great Basin (SGBSN) and portable seismograph networks ....

Figure 2. Map showing the USGS portable seismograph network, Little Skull Mountain mainshock, and

Figure 3. Geology map of Little Skull Mountain and the surrounding region showing the USGS portable

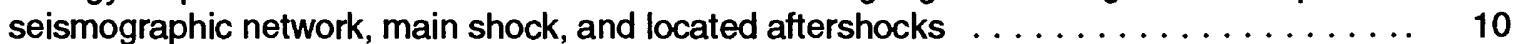

Figure 4. Plots of the drift rate measurements of each recorder clock $\ldots \ldots \ldots \ldots \ldots \ldots \ldots$ 


\section{Introduction}

On 29 June 1992 at 10:14:22.4 a magnitude 5.6(M $\left.\mathrm{M}_{\mathrm{L}}\right)$ earthquake occurred at Little Skull Mountain (LSM), Nevada. The hypocenter determined by the USGS from network data was $36.718^{\circ}$ North, $116.292^{\circ}$ West, at a depth of $9.5 \mathrm{~km}$ below sea level. This was one of the largest events to occur in the vicinity of the proposed site of a high radioactive waste repository at Yucca Mountain. The earthquake's epicenter was approximately $20 \mathrm{~km}$ to the southeast of the proposed repository site (PRS).

Historically, written records of reported earthquakes in the southern Great Basin (SGB) began emerging around 1860. Since that time, the number of intermediate to major earthquakes has been small in the vicinity of the PRS (Meremonte and Rogers, 1987; Harmsen and Bufe, 1991). Table 1 shows the frequency of earthquakes $\geq M_{L}=5.0$ within $150 \mathrm{~km}$ of Yucca Mountain.

Table 1. Summary of earthquakes $\geq M_{L}=5.0$ in the southern Great Basin within $150 \mathrm{~km}$ of PRS.

\begin{tabular}{rrlllllll}
\hline DATE \& TIME & (UTC) & IAT (N) & LON (W) & I (MM) & $\mathbf{M}_{\mathbf{L}}$ & DIST (km) & COMMENTS \\
\hline 1872 & 326 & $2: 30:----$ & 36.5 & 118. & XI & 8.3 & 143.2 & Owens Valley \\
1939 & 613 & $17: 15: 32.07$ & 37.0 & 117.2 & VI & 5.0 & 70.9 & \\
1940 & 310 & $18: 1: 53.31$ & 37.4 & 114.9 & IV & 5.0 & 147.8 & \\
1945 & 614 & $3: 31: 15.66$ & 37.0 & 117.4 & VI & 5.0 & 88.2 & \\
1949 & 211 & $21: 5: 23.30$ & 37.0 & 117.8 & VI & 5.6 & 120.9 & \\
1954 & 720 & $0: 11: 38.29$ & 38.2 & 116.4 & -- & 5.0 & 148.3 & \\
196757 & $18: 1: 36.10$ & 37.0 & 115.0 & IV & 5.1 & 131.0 & \\
1973 & 621 & $14: 45: 0.61$ & 37.1 & 116.0 & VI & 5.4 & 47.2 & \multirow{2}{*}{ Little Skull Mt. } \\
1992 & 629 & $10: 14: 22.40$ & 36.721 & 116.294 & -- & 5.6 & 20.5 & \\
\hline
\end{tabular}

MM denotes Modified Mercalli scale

Within $50 \mathrm{~km}$ of the PRS one event was reported, within $100 \mathrm{~km}$ three events were reported, and within 150 $\mathrm{km}$ eight events were reported. Considering these earthquakes, the Owens Valley event was the most capable to have incurred a probable damaging effect upon the integrity of the proposed repository. Yet on June 29, 1992, the LSM earthquake of $M_{L}=5.6$ occurred within 21 kilometers of the proposed repository.

The LSM event underscored all previous years of earthquake monitoring by the southern Great Basin Seismic Network (SGBSN). Since August, 1978, the SGBSN has been continuously recording earthquakes (both digital and analog) with a dense sub-array at Yucca Mountain, Nevada (see Figure 1 and 2). Through this span of time ( $\approx 14$ years), no other event of the LSM earthquake magnitude has occurred within $50 \mathrm{~km}$ of the PRS (see Table 2).

Table 2. List of earthquakes $\geq M_{L}=2.5$ within $50 \mathrm{~km}$ of the PRS.

\begin{tabular}{rrrlrlll}
\hline DATE \& TIME (UTC) & LAT(N) & LON(W) & DEPTH & $\mathbf{M}_{\mathbf{L}}$ & DIST $(\mathbf{k m )}$ & USGS TOPO REGION \\
\hline 1979611 & $20: 26: 59.26$ & 37.295 & 116.475 & 7.00 & 2.67 & 49.4 & SILENT BUTTE \\
19790629 & $2: 11: 47.66$ & 37.177 & 116.090 & 7.00 & 2.67 & 48.8 & OAK SPRING \\
19800725 & $23: 10: 39.65$ & 37.260 & 116.483 & -0.92 & 2.86 & 45.6 & SILENT BUTTE \\
19800731 & $19: 26: 15.71$ & 37.073 & 116.004 & 7.00 & 2.68 & 47.4 & YUCCA FLAT \\
19811013 & $14: 47: 53.58$ & 37.060 & 116.950 & 7.00 & 2.56 & 49.6 & SPRINGDALE \\
19811119 & $21: 40: 53.44$ & 37.057 & 116.948 & 1.46 & 2.51 & 49.3 & SPRINGDALE \\
19811216 & $21: 5: 0.33$ & 37.110 & 116.117 & 7.47 & 2.90 & 41.8 & YUCCA FLAT \\
19841110 & $16: 40: 0.41$ & 36.985 & 116.056 & 3.49 & 2.99 & 38.8 & YUCCA LAKE
\end{tabular}


Table 2 (continued). List of earthquakes $\geq M_{L}=2.5$ within $50 \mathrm{~km}$ of the PRS.

\begin{tabular}{rrrlrlll}
\hline DATE & \multicolumn{1}{l}{ TIME (UTC) } & LAT(N) & LON(W) & \multicolumn{1}{c}{ DEPTH } & \multicolumn{1}{l}{$\mathbf{M}_{\mathbf{L}}$} & DIST $(\mathbf{k m})$ & USGS TOPO REGION \\
\hline 19841209 & $19: 40: 0.67$ & 37.273 & 116.500 & 6.46 & 3.49 & 47.1 & TRAIL RIDGE \\
19850507 & $20: 6: 10.45$ & 36.603 & 116.050 & 8.82 & 2.66 & 45.7 & SPECTER RANGE SE \\
19850613 & $1: 31: 35.21$ & 37.258 & 116.470 & 2.83 & 2.70 & 45.3 & SILENT BUTTE \\
19850730 & $15: 4: 24.31$ & 37.146 & 116.879 & 5.31 & 2.96 & 49.8 & SPRINGDALE \\
19860702 & $8: 10: 21.68$ & 36.599 & 116.409 & 2.87 & 2.95 & 28.2 & LATHROP WELLS SW \\
19860822 & $14: 44: 17.60$ & 36.631 & 116.341 & 3.02 & 2.82 & 26.5 & STRIPED HILLS \\
19861210 & $15: 3: 52.59$ & 36.633 & 116.330 & 2.90 & 2.61 & 26.7 & STRIPED HILLS \\
19870630 & $16: 5: 0.14$ & 36.995 & 116.054 & -0.34 & 3.16 & 39.4 & YUCCA LAKE \\
19890521 & $23: 53: 53.00$ & 36.853 & 115.947 & 9.92 & 2.58 & 45.6 & FRENCHMAN FLAT \\
19891010 & $19: 39: 52.26$ & 36.827 & 116.262 & 0.14 & 2.51 & 17.7 & JACKASS FLATS \\
19900207 & $15: 9: 45.76$ & 37.235 & 116.413 & 2.01 & 2.83 & 42.9 & SCRUGHAM PEAK \\
19900215 & $13: 35: 12.26$ & 37.193 & 116.379 & 7.12 & 2.76 & 38.7 & SCRUGHAM PEAK \\
19900920 & $19: 4: 35.61$ & 36.902 & 116.651 & 0.06 & 2.55 & 18.1 & BARE MTN \\
19901014 & $0: 26: 48.87$ & 37.252 & 116.499 & 1.82 & 2.66 & 44.8 & SILENT BUTTE \\
19901116 & $2: 0: 51.65$ & 37.158 & 116.867 & 10.85 & 2.59 & 49.9 & SPRINGDALE \\
19910914 & $20: 4: 43.14$ & 37.227 & 116.422 & 2.93 & 3.10 & 42.0 & SCRUGHAM PEAK \\
19911130 & $6: 45: 56.39$ & 36.739 & 116.215 & 5.58 & 2.82 & 25.0 & SPECTER RANGE NW \\
19920229 & $740: 33.36$ & 37.042 & 116.169 & -0.29 & 2.77 & 33.4 & TIPPIPAH SPRING \\
\hline
\end{tabular}

The LSM earthquake was significant because of its close proximity to Yucca Mountain and because of its occurrence only 22 hours after the MS=7.6 Landers, California, earthquake of June 28, 1992 at 11:57:34.1. This fact coupled with the increased seismic activity across the southwest that began after the Landers earthquake has spawned some considerations on whether the LSM event was triggered. Although the earthquakes are separated by $280 \mathrm{~km}$ across the Furnace Creek - Death Valley fault and Garlock fault zones, the interrelationships of those two tectonic regimes are not well known (Brockman et al, 1992; Rogers et al, 1991). Because of these reasons and of the relevance to the proposed high radioactive waste repository at Yucca Mountain, Nevada, the U.S. Geological Survey (USGS) mounted an effort to digitally record the aftershock sequence of the LSM earthquake with support from the Yucca Mountain Project Office (YMPO).

\section{Geologic Setting}

The epicentral region is located on the southern edge of the Nevada Test Site (NTS area 25) in southeastern Nevada about $120 \mathrm{~km}$ northwest of Las Vegas, Nevada. Figure 3 is a geology map of the epicentral area enclosed by Calico Hills/Lookout Peak on the north, Skull Mountain/upper Rock Valley on the east, Specter Range/Striped Hills on the south and northern Amargosa Desert/Yucca Mountain on the west with LSM dominating the center on the southern edge of Jackass Flats. Structurally, the area is a system of northeast-striking faults, folds, and topographic trends (Frizzel and Shulters, 1990). Overall, the lithology to the southeast of Rock Valley consists of Paleozoic siltstones, limestones and dolomites from Middle Cambrian through Upper Devonian. To the northwest the lithology consists of a relatively thin layer of Tertiary ash-flow tuffs and basalts underlain by the Paleozoic sequence. Evidence of the underlying Paleozoic rocks can be observed in outcrop exposures of limestones and dolomites in the Calico Hills (Moldonado, 1985). Table 3 describes the geology of the major topographic structures surrounding LSM. Annotated at the end of 
each geologic description are the portable stations that were located in that class of geology/topographic structure.

Table 3. Geology of the major topographic structures surrounding LSM; and the portable station located in that class of geology/topographic structure.

YUCCA MTN. - Compositionally zoned compound cooling unit of ash-flow tuff (upper quartz latite, middle rhyolite, and lower high-silica rhyolite); H50

CALICO HILLS / SHOSHONE MTN. - Rhyolite to quartz latite ash-flow tuffs (multiple flow compound cooling unit, large volume, densely welded, zoned thyolite to quartz latite ash-flow tuff; And compound cooling unit, nonwelded to densely welded high-silica rhyolite with caprock of quartz latitic ash-flow tuff; CAL

LOOKOUT PEAK - Rhyodacitic (aphanitic granodiorite) and dacitic (quartz dionite) lava flows and flow breccia that contain primary horndblende.

VALLEYS (JACKASS FLATS, ROCK VALLEY, ETC.) - Unconsolidated to moderately cemented alluvial fan, slope wash, flood plain, and stream bed deposits (caliche locally); thickness up to $600 \mathrm{~m}$; SPE, COM, JAC, LAT, CL0, ARO, MVR, TCT, TWR, SLS, ARY, \& HUDDLE TEST

SKULL MTN. (Northeast part) - Rhyodacitic (aphanitic granodiorite) and dacitic (quartz diorite) lava flows and flow breccia that contain primary horndblende.

SKULL MTN. (Southwest part) - Basalts (plagioclase-porphyritic olivine basalt, porphyritic clinopyroxeneolivine basalt, and quartz-olivine basaltic andesite).

LOCAL STRUCTURES IN VALLEY EAST OF SKULL MT. - sedimentary and tuffaceous sedimentary rocks; TPP

SPECTER RANGE - Banded, thinly laminated, locally oolitic or nodular, limestone and dolomite and minor siltstone; SPW

STRIPED HILLS - Limestone, silty limestone, dolomite and limestone conglomerates.

TOWER HILL WEST OF FIELD OFFICE CONOTROL (FOC) - Black dense, vesicular, scoriacious, stony basalt with quartz phenocrysts; TOW

LITTLE SKULL MTN. - Basalts (plagioclase-porphyritic olivine basalt, porphyritic clinopyroxene-olivine basalt, and quartz-olivine basaltic andesite); LSD

Frizzell and Shulters, 1990

\section{Description of the Instrumentation}


Instrumentation included Sprengnether DR200 and Refraction Technology, Inc., (REFTEK) 72A-02 digital and Sprengnether MEQ800 analog recording systems. The DR200 is a 12 bit system with a gain ranging analog to digital converter (ADC) that can record up to 200 samples/second on 4 channels. All DR200s have 7 pole (42db/octave) anti-aliasing filters with corner frequencies at $50 \mathrm{~Hz}$. The $72 \mathrm{~A}-02$ is a 16 bit system that can record up to eight data streams. Each data stream is determined by the selected channels (1-6 or any combination thereof), sample rate (up to 1000 samples/second), and a trigger type (event, time, level, continous, etc.). The ADC samples at a constant rate of 1000 samples/second per channel. The REFTEKs have 6 pole (36db/octave) anti-aliasing filters with corner frequencies at $250 \mathrm{~Hz}$. The MEQ800 is a smoked paper drum recorder with selectable gains and low and high pass filters. Parameters for each instrument are outlined in the station summaries in appendix $A$.

Various seismometers were used in combination with the above recording instruments. We used Mark Products L22, L28 and L4C, Sprengnether S6000, and Teledyne Geotech S13 seismometers. The L22, and $\mathrm{S6000s}$ are three component packages while the L28s, L4Cs and the S13s are single component packages. The natural frequencies and polarities of each package are outlined in the station summaries in appendix $\mathrm{A}$.

For timing on the DR200 MEQ800 systems we used the Geostationary Operational Environmental Satellite (GOES) as our absolute time reference. Master clocks (MC) synced to the GOES were used to measure the clock corrections (CC) on the recording instruments. The MCs consisted of three Sprengnether TS400s and a USGS, in house, timing system (MCIII).

Timing on the REFTEK instruments was maintained by an Omega radio clock synchronized to UTC. The Omega system has the ability to initiallize or update the perpetual clock maintained by the central processor unit (CPU) of the recorder. $\mathrm{CC}$ updates are issued to the CPU clock whenever the recorder first locks or relocks to the Omega signal or when the internal comparator sees a phase error larger than the factory preset range. Clock updates are recorded with the seismic data during normal operation of the instruments.

\section{Deployment}

The Nevada Test Site (NTS) was an ideal location to operate a portable seismographic network. With the cooperation of the test site authorities we were able to install the temporary network with relative ease and quickness. Only minor difficulties were encountered such as the condition of the desert roads, the nearby habitation of a desert tortoise (which meant move to a new locality), or the finding of good rock sites within 1-2 focal depths (since most of the area is overlain by several hundred kilometers of sediments). The weather was warm with below normal temperatures (although they still climbed above $100^{\circ}$ ).

Within 38 hours after the main shock, eight DR200 and five MEQ800 instruments were installed surrounding the aftershock zone with the widest gap of $115^{\circ}$ to the south. However, the gap was reduced to about $40^{\circ}$ when including the permanent SGBSN seismographic stations (54 stations total, see figure 1) and the USNSN station, TPNV. The average separation between the USGS portable stations was $\approx 7.0 \mathrm{~km}$ which was near 1 focal depth of the depth range for the LSM aftershock series. Three REFTEK instruments were installed within two days to supplement the initial portable network. By the end of the recording period a total of seventeen digital and analog instruments were deployed and operating (see figure 2). Table 4 is a 
summary of the names, recorder types (digital or analog), general geographic locations, coordinate locations and elevations of the portable stations.

Table 4. Summary characteristcs of the portable stations.

\begin{tabular}{|c|c|c|c|c|c|c|c|}
\hline STATION & TYPE & GEOGRAPHIC LOCATION & LAT & $(\mathbf{N})$ & LON & (w) & ELEVATION (m) \\
\hline ARO & digital & Jackass Flats, middle & $36^{\circ}$ & $49.74^{\prime}$ & $116^{\circ}$ & $16.26^{\prime}$ & 1160 \\
\hline ARY & digital & Jackass Flats, middle & $36^{\circ}$ & $49.74^{\prime}$ & $116^{\circ}$ & $16.26^{\prime}$ & 1160 \\
\hline CAL & digital & Calico Hills, $\mathrm{s}$ & $36^{\circ}$ & $51.42^{\prime}$ & $116^{\circ}$ & $17.45^{\prime}$ & 1268 \\
\hline CLO & digital & Jackass Flats, N & $36^{\circ}$ & $50.32^{\prime}$ & $116^{\circ}$ & $20.29^{\prime}$ & 1177 \\
\hline $\mathrm{COM}$ & digital & S. of Skull Mountain & $36^{\circ}$ & $43.72^{\prime}$ & $116^{\circ}$ & $13.41^{\prime}$ & 1169 \\
\hline H5O & digital & Yucca Mountain, top & $36^{\circ}$ & $51.40^{\prime}$ & $116^{\circ}$ & $27.94 '$ & 1475 \\
\hline JAC & digital & Jackass Flats, SW & $36^{\circ}$ & $45.84^{\prime}$ & $116^{\circ}$ & $22.43^{\prime}$ & 949 \\
\hline LAT & digital & Amargosa Desert, $\mathrm{N}$ & $36^{\circ}$ & $40.65^{\prime}$ & $116^{\circ}$ & $22.84^{\prime}$ & 849 \\
\hline LSD & digital & Little skull Mtn., top & $36^{\circ}$ & $43.81^{\prime}$ & $116^{\circ}$ & $19.61^{\prime}$ & 1177 \\
\hline MVR & analog & Jackass Flats, $\mathrm{NE}$ & $36^{\circ}$ & $51.65^{\prime}$ & $116^{\circ}$ & $13.60^{\prime}$ & 1326 \\
\hline SLS & analog & S. of Little skull Mtn. & $36^{\circ}$ & $42.00^{\prime}$ & $116^{\circ}$ & $16.02^{\prime}$ & 1045 \\
\hline SPE & digital & Mercury Valley, w & $36^{\circ}$ & $39.22^{\prime}$ & $116^{\circ}$ & 7.09 ' & 1076 \\
\hline SPW & digital & Specter Range, W & $36^{\circ}$ & $41.30^{\prime}$ & $116^{\circ}$ & $10.69^{\prime}$ & 1073 \\
\hline TCT & analog & Wahmonie Flat, $\mathrm{S}$ & $36^{\circ}$ & $48.34^{\prime}$ & $116^{\circ}$ & $8.95^{\prime}$ & 1352 \\
\hline TOW & digital & Tower Hill, middle & $36^{\circ}$ & $47.27^{\prime}$ & $116^{\circ}$ & $19.70^{\prime}$ & 1111 \\
\hline TPP & analog & Upper Rock Valley & $36^{\circ}$ & $43.37^{\prime}$ & $116^{\circ}$ & $7.74^{\prime}$ & 1158 \\
\hline TWR & analog & Jackass Flats, E & $36^{\circ}$ & $46.43^{\prime}$ & $116^{\circ}$ & $14.29^{\prime}$ & 1109 \\
\hline
\end{tabular}

See appendix A for a detailed description of the stations.

At the termination of the aftershock survey we performed a "huddle test" by installing all seventeen instruments (with their original recorder and seismometer) at the site of the REFTEK station AR0. The purpose of this experiment was to find out the agreement of the instrument responses and timing. Appendix A outlines the configuration of the huddle test and the instrument parameters.

\section{Clock Corrections}

Clock corrections (CC) are measured values of the differences between a time reference and a field instrument clock and when added to the time of the field instrument clock will yield the "true" time. Without precise CCs, uncertainties in timing would be impossible to determine. To measure the CCs on the individual recording instruments we used master clocks $(\mathrm{MC})$ as intermediate time references between the absolute GOES time and the recorder clock. Usually, a CC between GOES and each MC was measured in the morning and in the evening for timing continuity. Then, the MCs were used in the field as our time references to measure the CCs on each instrument. Actual measurement of the CCs were performed by comparing the second pulse of the MC with the second pulse of each recorder clock using an oscilloscope; and the same was true for the CC between the GOES and each MC. Appendix A outlines the CCs measured between the recorder clocks and the MCs; and appendix B outlines the CCs measured between the MCs and the absolute time reference GOES.

CCs for the DR200 recorders and the MEQ800 recorders have been outlined in a USGS report to the Yucca Mountain Project Office (YMPO) (personal comm. Gomberg, 1993). Figure 4 displays the drift rate measurements and the estimate of the $\mathrm{CC}$ uncertainties. The drift rates include both the drift of the MCs and 
the recorder clocks. The CCs range between 2-50 milliseconds with the largest corrections associated with the MEQ800 instruments. However, the uncertainties in the CCs are smaller or of the same order as those from visually scaled arrival times. For the REFTEK recorders, the CCs are resolved by an internal comparator which routinely checks the time difference between the internal CPU clock and the external radio clock (a clock phase error) and records the phase error with the seismic data.

\section{Field Operation and Processing}

As stated earlier the ease of maintaining the portable network was much facilitated by the convenience of the earthquake occurring on a U.S. Govenrment facility. Although this facility had restrictions on our movements and sometimes on the hours we worked, the use of hand held radios to connect us to the Field Office Control (FOC) minimized the limits on our freedom to maintain the instruments properly and efficiently.

With respect to maintaining the mounting collection of data, we were able to setup a local area network (LAN) at Test Cell C in area 25. The LAN was established and maintained by Robert Banfill of Small Systems Support, Big Water, Utah. Connected to the LAN were two desk top PCs, two portable PCs, and a laser printer. A minature computer center was at our disposal that enabled us to manage data from all three types of recording instruments (DR200s, REFTEKs, and MEQ800s). Furthermore, it enabled a "rough" database to be built composed of merged data from both DR200 and REFTEK formats in which the waveforms could be displayed together and earthquake parameters picked for preliminary processing. As a result we were able to produce a short report (with maps and figures) for the YMP/QA authorities several days after we began for a briefing and to monitor our quality assurance procedures.

\section{Acknowledgements}

The cooperation of the NTS YMP office located at the FOC building was paramount in the success of this survey. They were able to give us all the required training for working safely and environmentally on the Nevada Test Site. Thanks. I would like to especially thank Jim Brooks, Don Gibbons, and Jim McDonald for their outstanding help in deployment and maintenance of the portable network and the use of their offices at Test Cell C. Chris Early of Refraction Technology, Inc., was also especially helpful in solving some of the technical problems incurred with the REFTEKs. His expertise is greatly appreciated. 


\section{References}

Brockman, S., Brooks, J., Carver, D., Cranswick, E., Duggar, J., Gomberg, J., Harmsen, S., Meremonte, M., Overturf, D., Shedlock, K., VanDreser, T., Worley, D., and Banfil, R., 1992, The June 29, 1992, Little Skull Mountain, Nevada, Earthquake: EOS Transactions of the American Geophysical Union, v. 73, no. 43, p. 354.

Frizell, V. A. and Shutters, J., 1990, Geologic Map of the Nevada Test Site, southern Nevada: U.S. Geological Survey Miscellaneous Investigation Series Map 1-2046, scale 1:100,000.

Harmsen, S. C. and Bufe, C. G., 1991, Seismicity and Focal Mechanisms for the southern Great Basin of Nevada and California; 1987 through 1989: U.S. Geological Survey Open-File Report 91-572, 208 p.

Meremonte, M. E. and Rogers, A. M., 1987, Historical Catalog of southern Great Basin Earthquakes 1868 1978: U.S. Geological Survey Open-File Report 87-80, 203 p.

Moldonado, Florian, 1985, Geologic Map of the Jackass Flats Area, Nye County, Nevada: U.S. Geological Survey Miscellaneous Investigation Series Map 1-1519, scale 1:48,000.

Rogers, A. M., Harmsen, S. C., Corbett, E. J., Priestly, K., and dePolo, D., 1991, The Seismicity of Nevada and some adjacent parts of the Great Basin, in Slemmons, D. B., Engdahl, E. R., Zoback, M. D., and Blackwell, D. D., eds., Neotectonics of North America: Boulder, Colorado, Geological Society of America, Decade Map Volume 1., p153-184. 


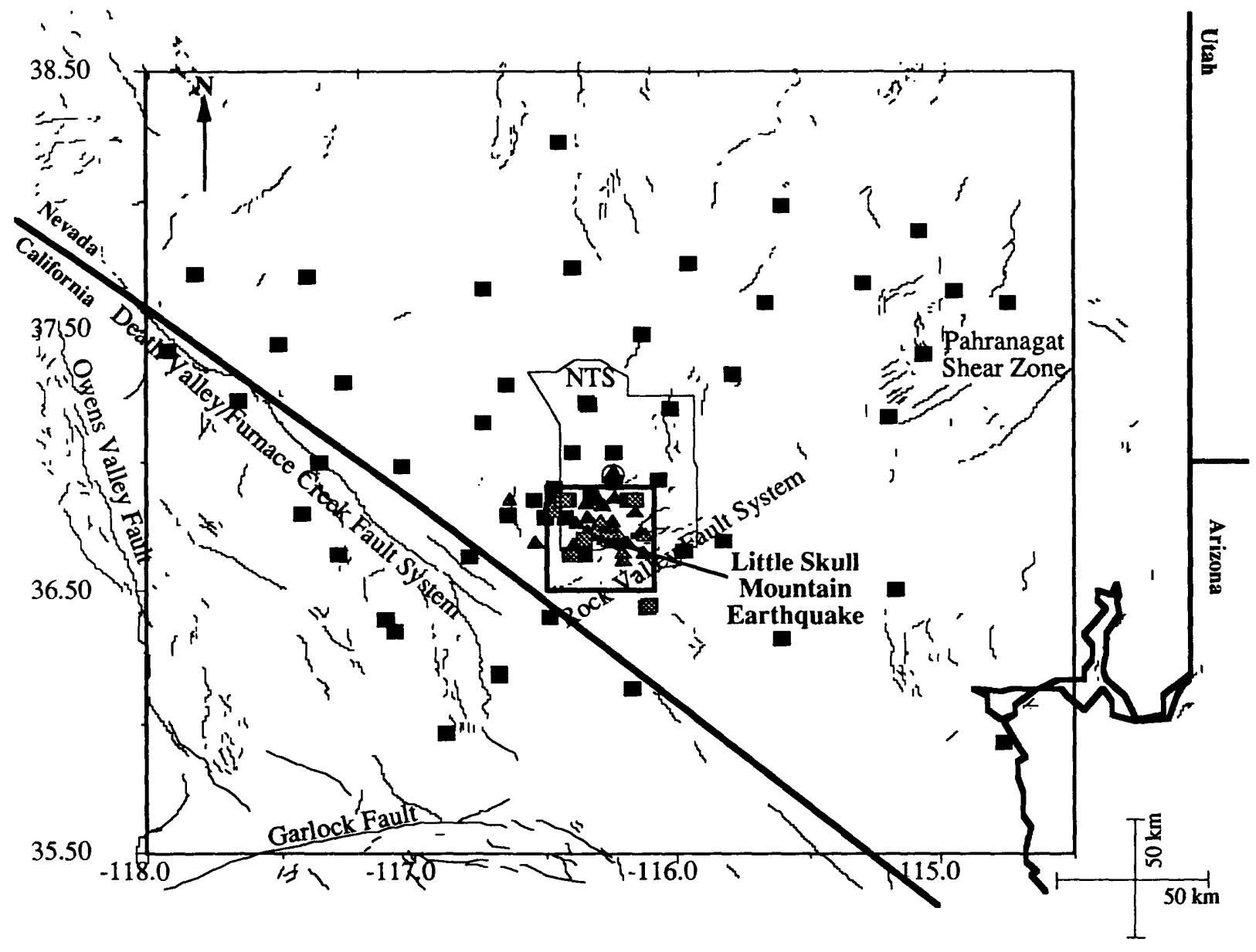

Sejsmic Stations

- SGBSN Permanent (FM)

A USGS Portable Digital (Reftek, DR200)

$\triangle$ USGS Portable Analog (MEQ)

$\Delta$ University of Nevada, Reno Portable Digital (Reftek)

Lawrence Livermore National Lab Portable Digital (Reftek)

O U.S. National Seismograph Network

Figure 1. Map showing the southern Great Basin (SGBSN) and portable seismograph networks. 


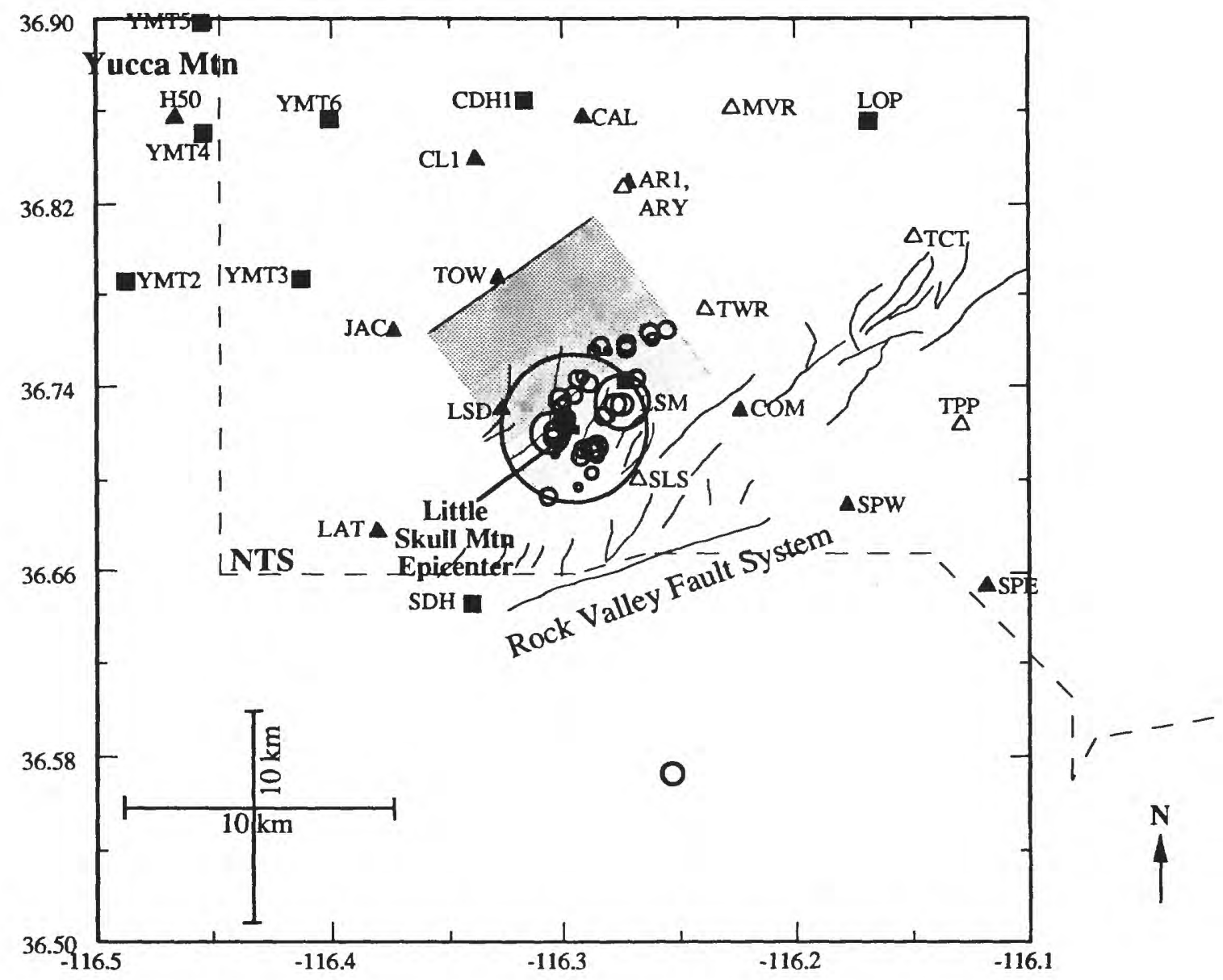

Data Sources:Seismic Stations

SGBSN Permanent (FM)

$\Delta$ USGS Portable Digital (Reftek, DR200)

$\triangle$ USGS Portable Analog (MEQ)

\section{Quaternary}

Fault Trace

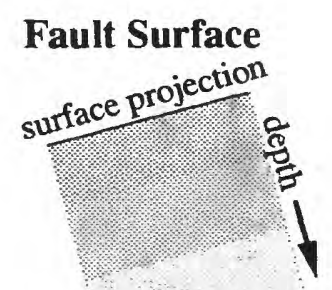

Epicenters

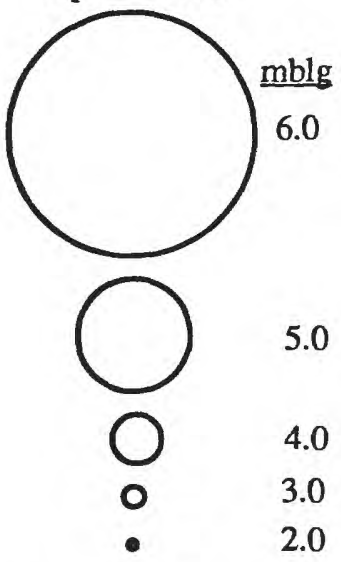

Figure 2. Map showing the USGS portable seismograph network, Little Skull Mountain mainshock, and aftershocks. 


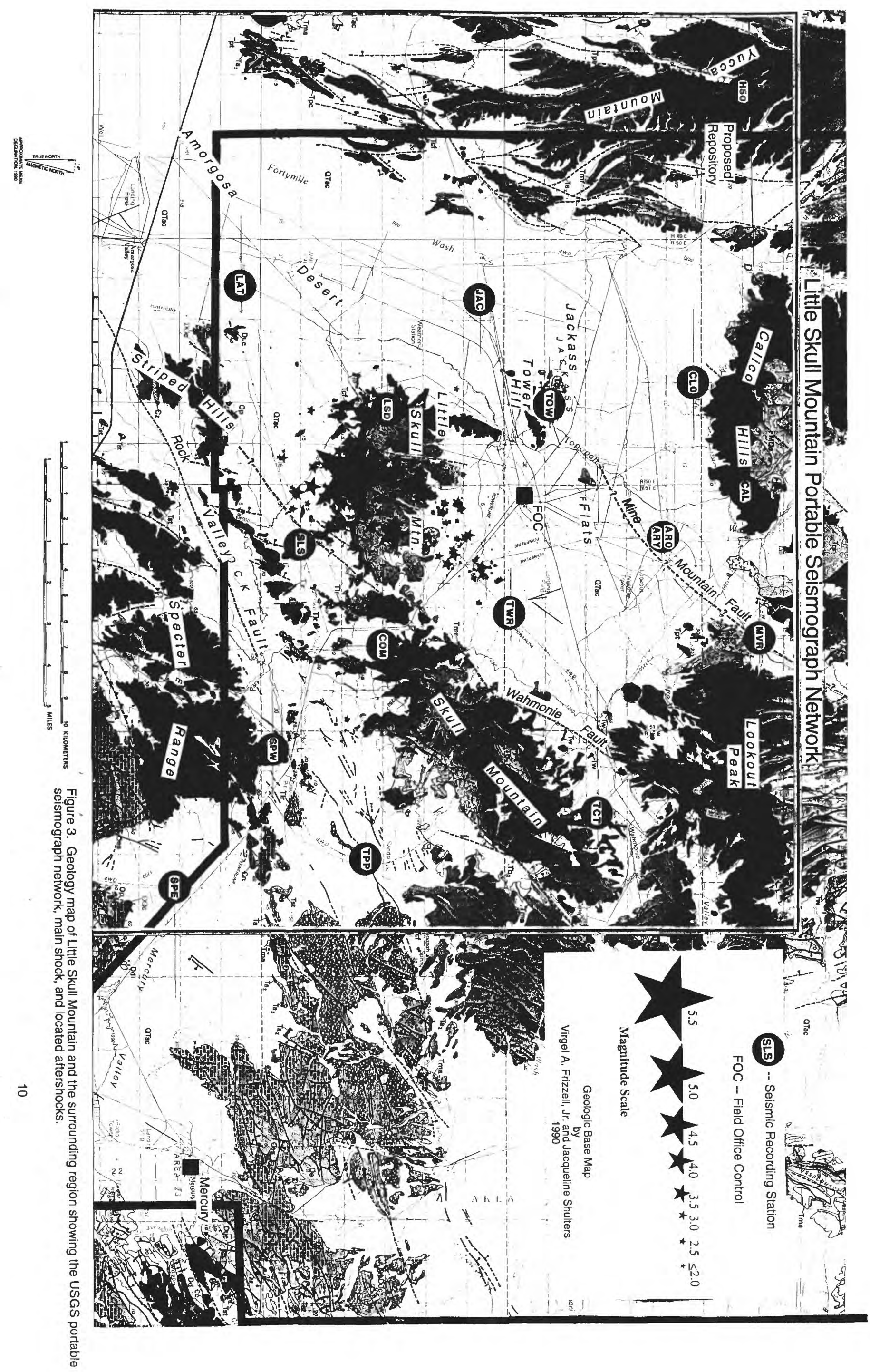



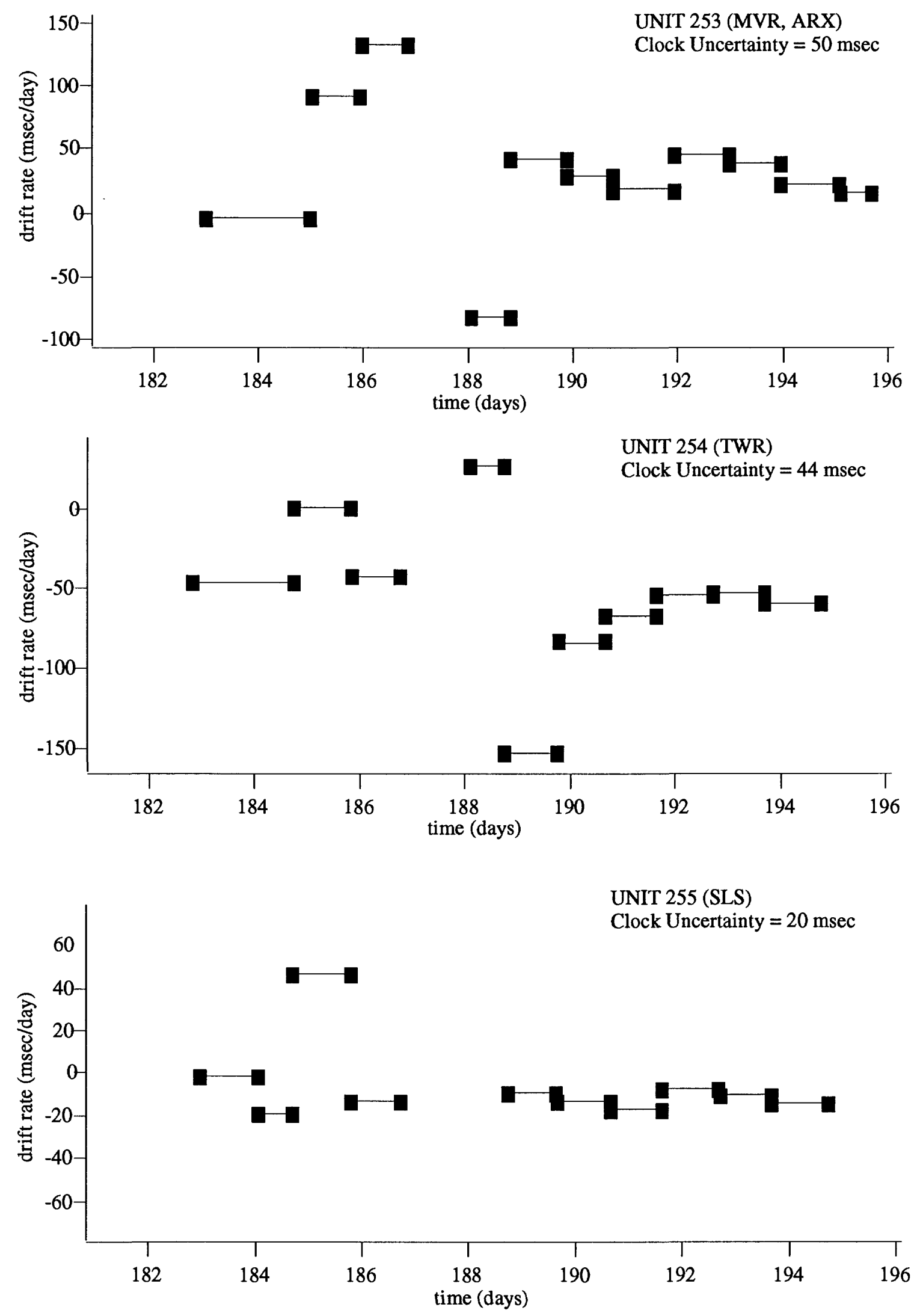

Figure 4a. Drift rate measurements and clock correction uncertainies for each recorder clock (instruments: 253, 254, 255). 

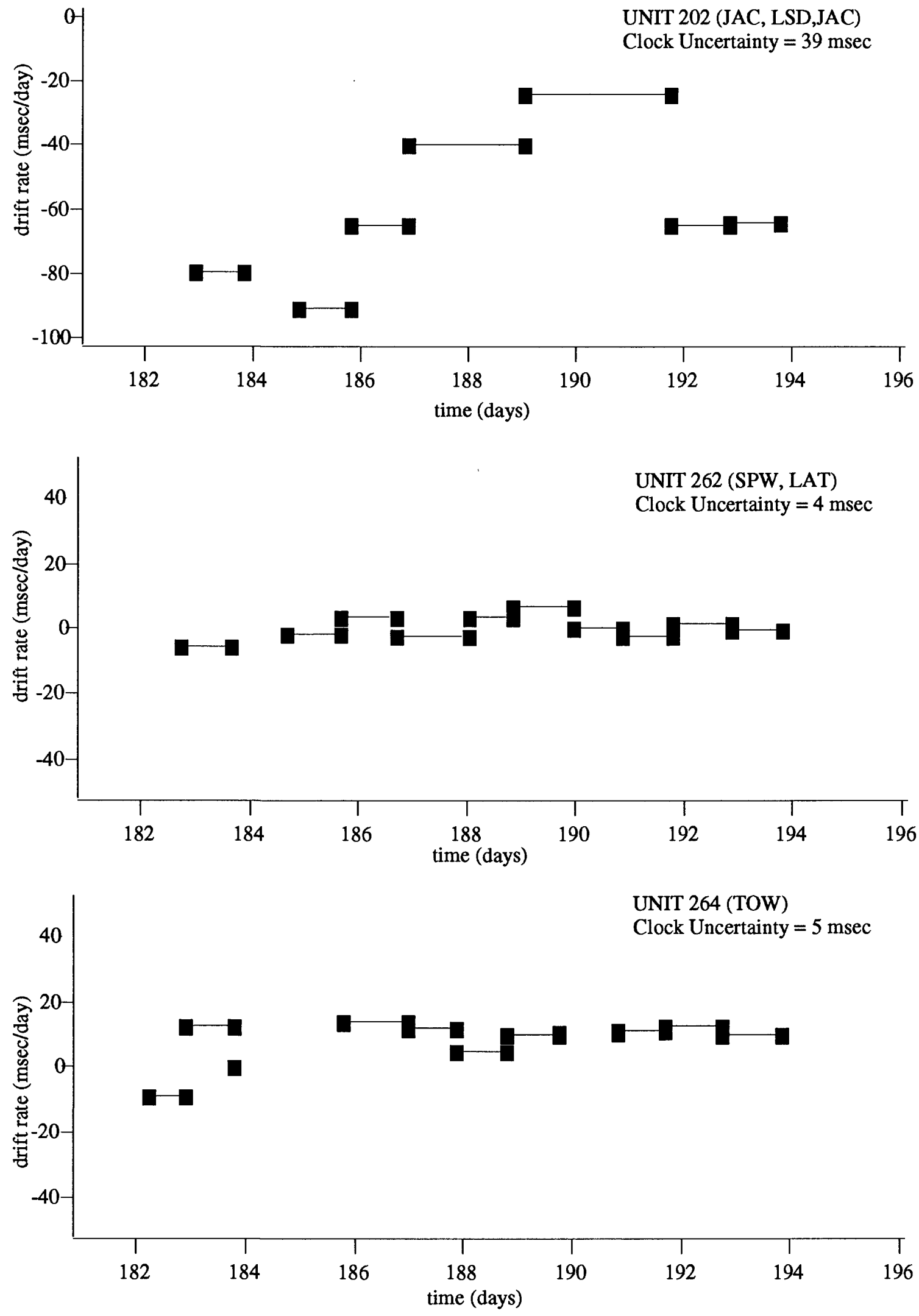

Figure 4b. Drift rate measurements and clock correction uncertainies for each recorder clock (instruments: 202, 262, 264). 

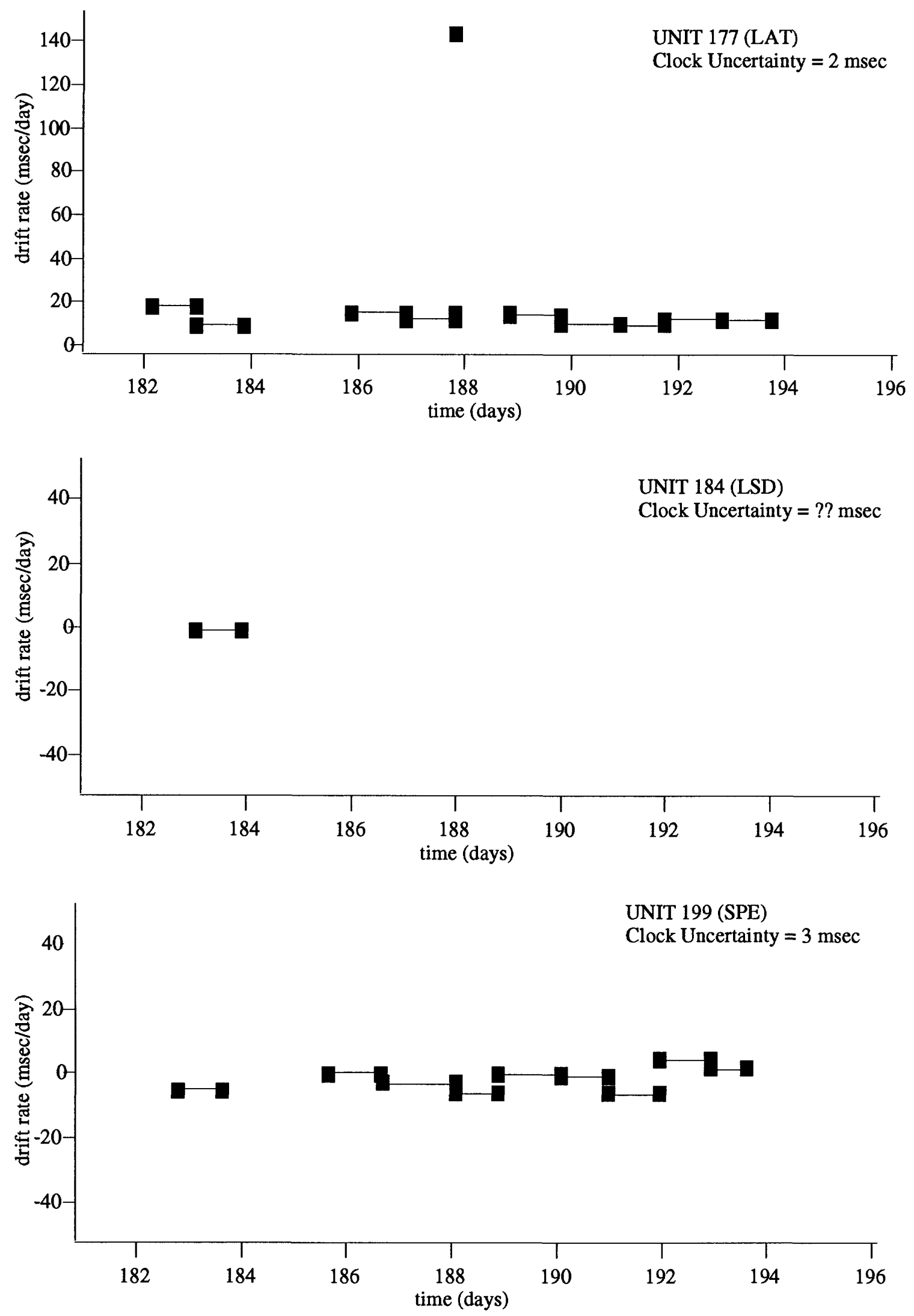

Figure 4c. Drift rate measurements and clock correction uncertainies for each recorder clock (instruments: 177, 184, 199). 

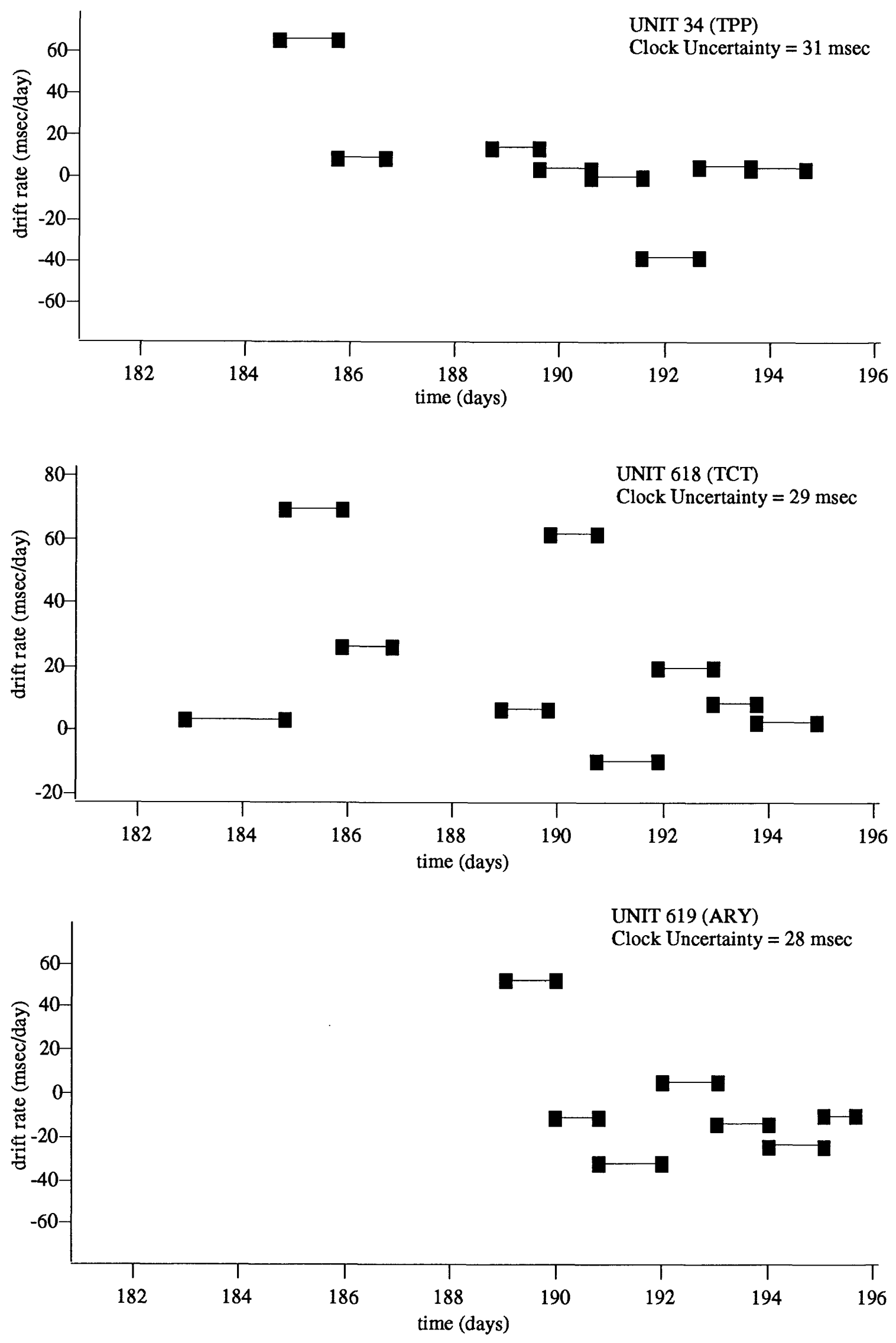

Figure 4d. Drift rate measurements and clock correction uncertainies for each recorder clock (instruments: $34,618,619$ ). 

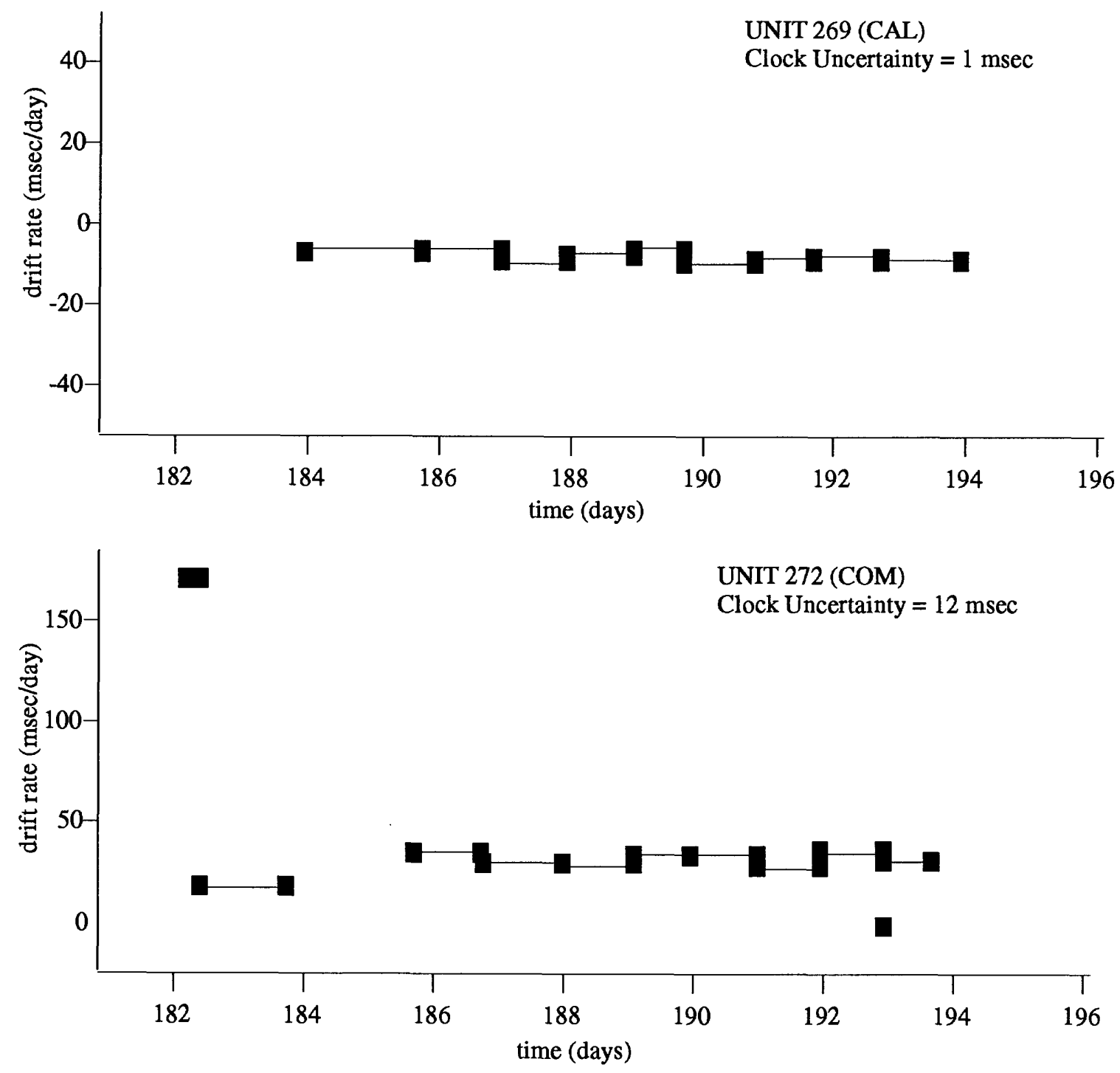

Figure 4e. Drift rate measurements and clock correction uncertainies for each recorder clock (instruments: 269, 272). 


\section{Appendix A}

\section{Station Summaries}

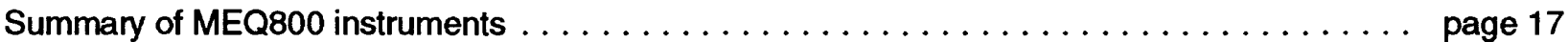

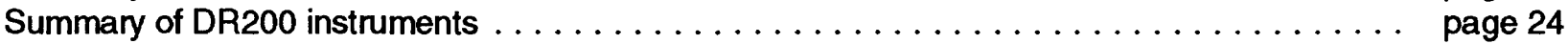

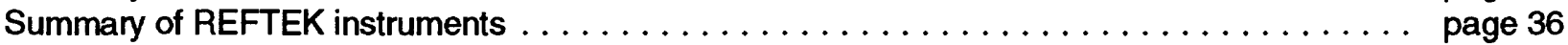

Summary of HUDDLE Test instruments $\ldots \ldots \ldots \ldots \ldots \ldots \ldots \ldots \ldots \ldots \ldots \ldots \ldots$ page 44

\section{Explanation of Station Summary Parameters}

Explanations of clock correction (CC) descriptors:

All clock corrections are measured in milliseconds unless otherwise noted. Below is a list of annotations that modify CC's to make clear the intent of the action taken when the CC was measured (the pound sign (\#), here, symbolizes an actual CC measurement):

For all cases below an instrument clock reset was performed interrupting the instrument's operation in conjunction with the noted action:

R\# - A CC measurement was determined

R? - No CC measurement was determined

R\#? - A CC measurement was determined but be aware of its integrity.

See "COMMENT" below entry for more detailed information.

For all cases below the instrument's operation was not interrupted (i.e., no instrument clock reset was performed) due to the noted action:

C\# - A CC measurement was determined

C? - No CC measurement was determined

C\#? - A CC measurement was determined but be aware of its integrity.

See "COMMENT" below entry for more detailed information.

? - no information is known about the instrument clock

Explanation of some instrument parameters:

The column header labels:

CC -- clock correction (milliseconds)

\# -- Tape label for DR200's or disk dump label for REFTEK's

MC -- Master Clock

SN -- Serial Number

GN -- Geographic North

The orientation of all seismometer components are in degrees.

All sample rates are measured in samples/second.

The annotation of a "Undf" in an entry field for data stream parameters indicates the associated parameter is undefined for either the CPU software implemented on the instrument or for that particular parameter setup shown. 


\section{Station Summaries of MEQ800 Instruments}


ARY

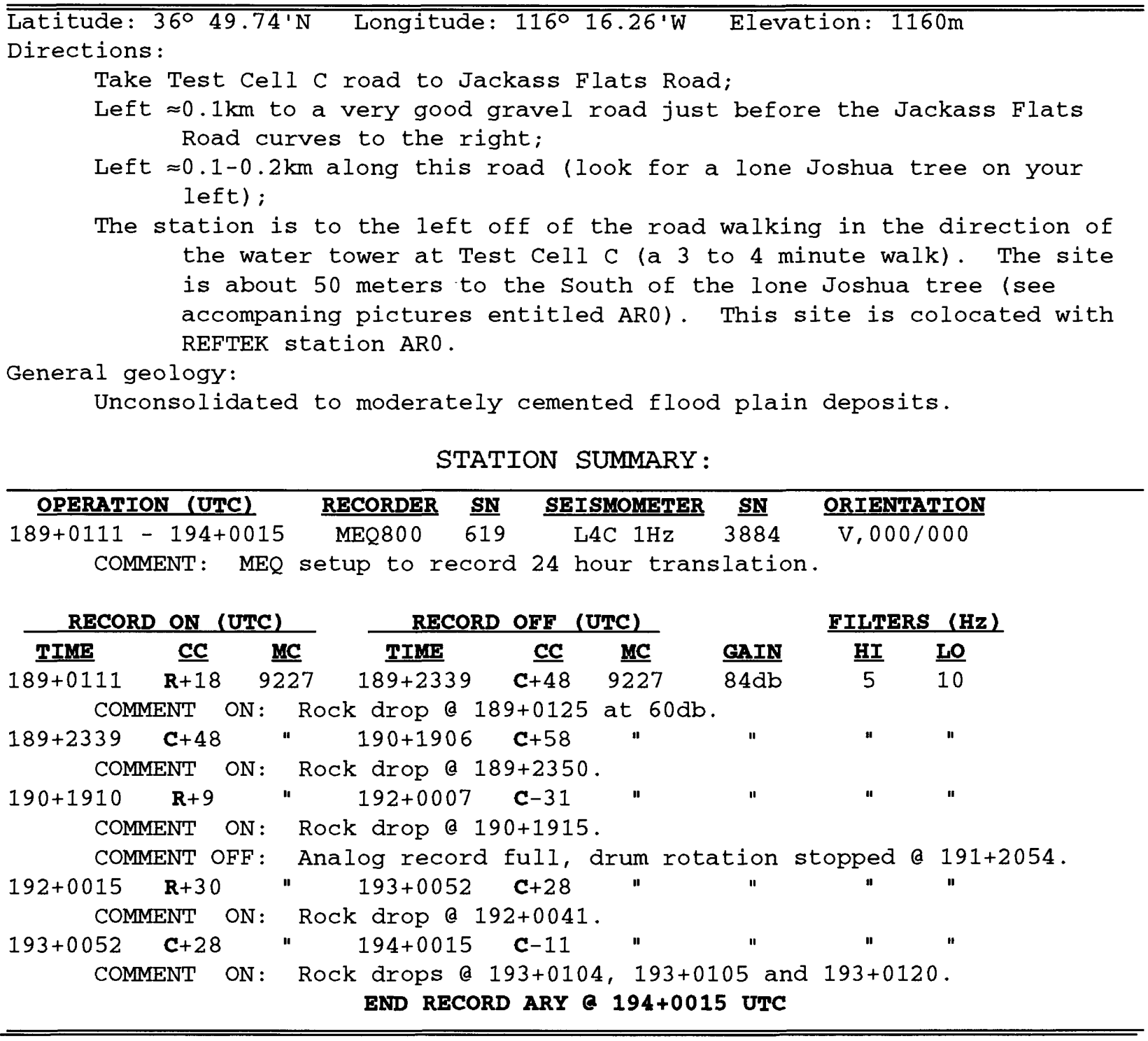




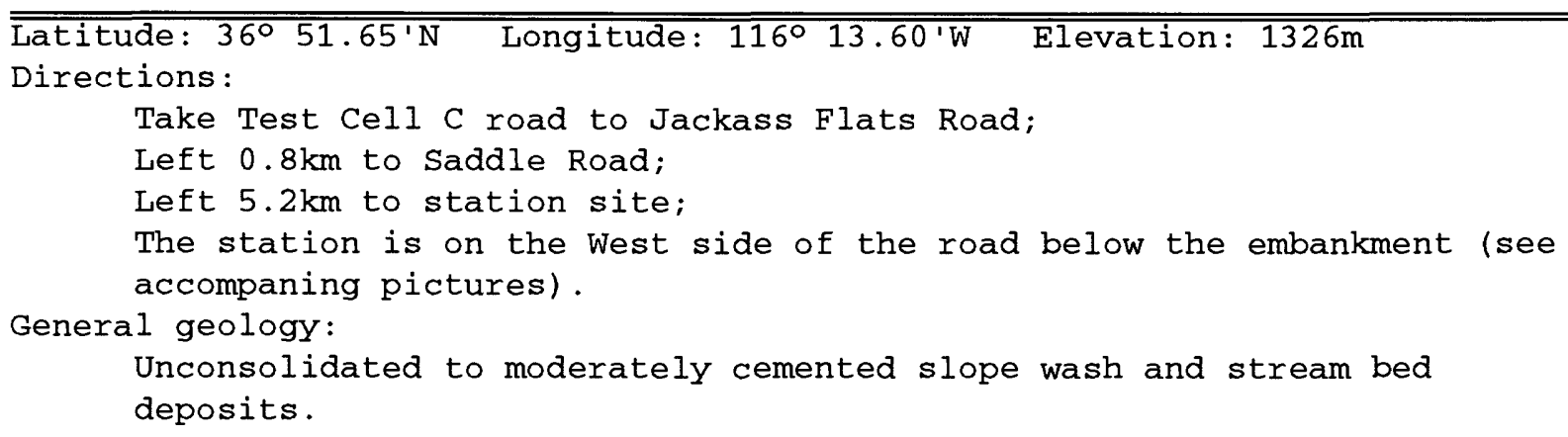

STATION SUMMARY:

\begin{tabular}{|c|c|c|c|c|c|}
\hline OPERATION (UTC) & RECORDER & $\underline{\text { SN }}$ & SEISMOMETER & $\underline{\mathbf{S N}}$ & ORIENTATION \\
\hline $18 \overline{2+2348-193+2224}$ & MEQ800 & 253 & $\mathrm{~L} 4 \mathrm{C} 1 \mathrm{~Hz}$ & 2295 & $\mathrm{~V}, 000 / 000$ \\
\hline
\end{tabular}

\begin{tabular}{|c|c|c|c|c|c|c|c|c|}
\hline \multicolumn{3}{|c|}{ RECORD ON (UTC) } & \multicolumn{3}{|c|}{ RECORD OFF (UTC) } & \multicolumn{3}{|c|}{ FILTERS (Hz) } \\
\hline TIME & CC & $\underline{M C}$ & TIME & CC & $M C$ & GAIN & $\underline{\mathrm{HI}}$ & LO \\
\hline $182+2348$ & $\mathbf{R}+14$ & 9523 & $184+2341$ & $c-20$ & 9227 & $90 \mathrm{db}$ & 5 & 10 \\
\hline $185+0014$ & $R+4$ & 9227 & $185+2228$ & $c+92$ & 9523 & " & $"$ & " \\
\hline
\end{tabular}

COMMENT ON: Reset clock to account for leap second a 182+23:59:60.

COMMENT ON: Modified MEQ to record 24 hour translation.

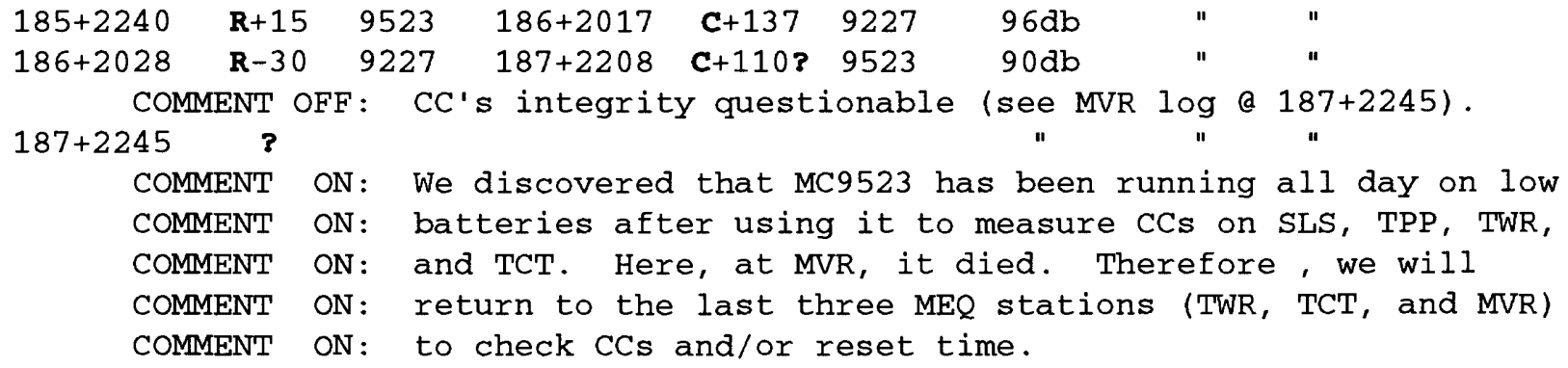


Latitude: $36^{\circ} 42.00^{\prime} \mathrm{N} \quad$ Longitude: $116^{\circ} 16.02^{\prime} \mathrm{W}$ Elevation: $1045 \mathrm{~m}$

Directions:

Take Test Cell C road to Jackass Flats Road;

Right $13.9 \mathrm{~km}$ to 4 wd road that parallels the old powerlines (trending WSW) just south of Little Skull Mountain;

Right $3.7 \mathrm{~km}$ on 4 wd trail winding under and over the fallen powerlines;

At this point you will be located on a small ridge between two dry stream beds near a telephone pole;

The station is North of the road approximately 50-60 meters along the

General geology: small ridge (a 1 to 2 miute walk; (see accompaning pictures).

Unconsolidated to moderately cemented slope wash and stream bed deposits.

STATION SUMMARY :

\begin{tabular}{|c|c|c|c|c|c|}
\hline OPERATION (UTC) & RECORDER & $\underline{\text { SN }}$ & SEISMOMETER & $\underline{\text { SN }}$ & ORIENTATION \\
\hline $182+2232-194+1655$ & 800 & 255 & $\mathrm{~L} 4 \mathrm{C} \quad 1 \mathrm{~Hz}$ & 3129 & $\mathrm{~V}, 000 / 000$ \\
\hline
\end{tabular}

COMMENT: MEQ setup to record 36 hour translation.

\begin{tabular}{|c|c|c|c|c|c|c|c|c|}
\hline \multicolumn{3}{|c|}{ RECORD ON (UTC) } & \multicolumn{3}{|c|}{ RECORD OFF (UTC) } & \multicolumn{3}{|c|}{ FILTERS $(\mathrm{Hz})$} \\
\hline TIME & $\underline{\mathbf{C C}}$ & $\underline{M C}$ & TIME & CC & $\underline{M C}$ & GAIN & $\underline{\mathrm{HI}}$ & LO \\
\hline $182+2232$ & $\mathbf{R}+5$ & 9227 & $184+0050$ & $c-32$ & 9227 & $96 \mathrm{db}$ & 5 & 10 \\
\hline $184+0112$ & $R+10$ & $"$ & $184+1623$ & $c+5$ & 9523 & $90 \mathrm{db}$ & $"$ & $"$ \\
\hline
\end{tabular}

COMMENT ON: Reset clock to account for leap second a 182+23:59:60.

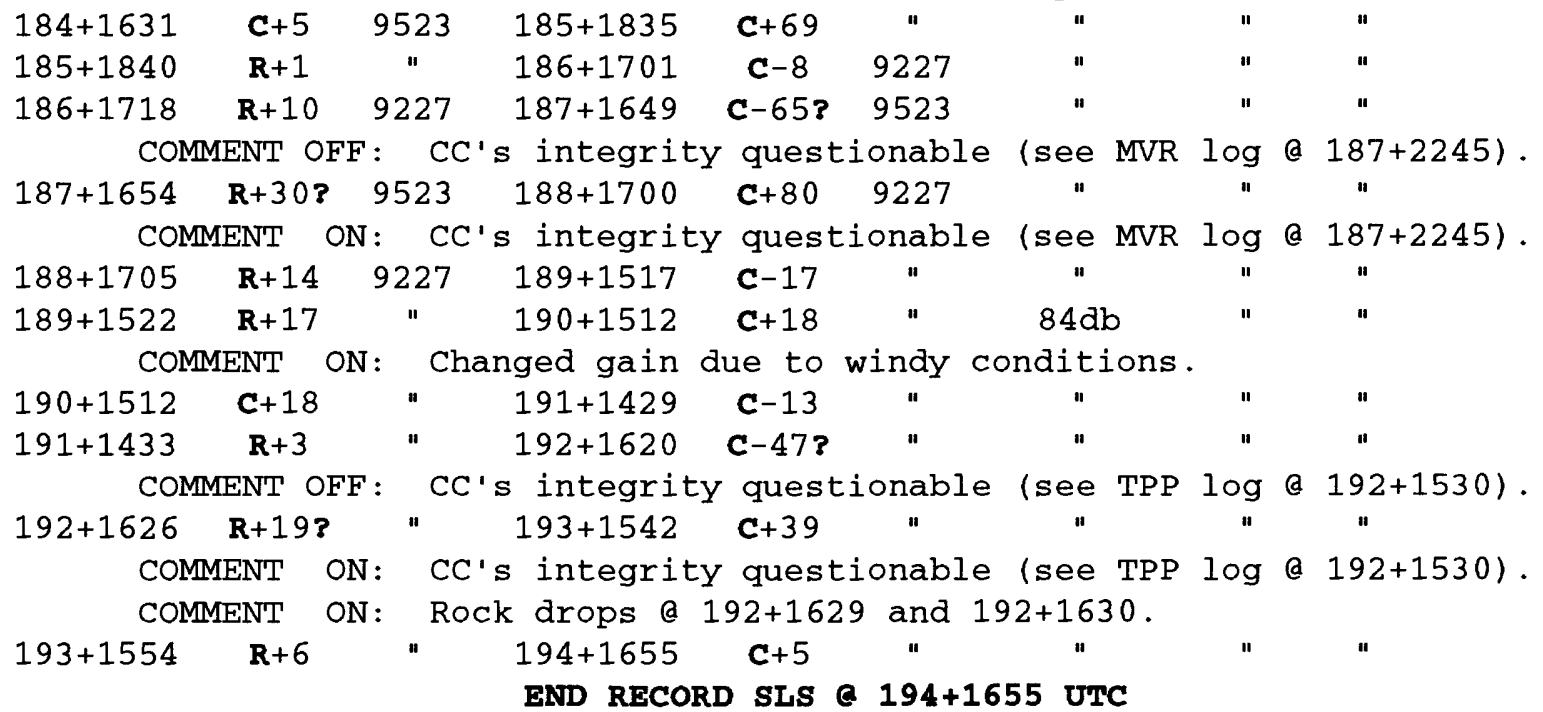

END RECORD SLS \& $194+1655$ UTC 


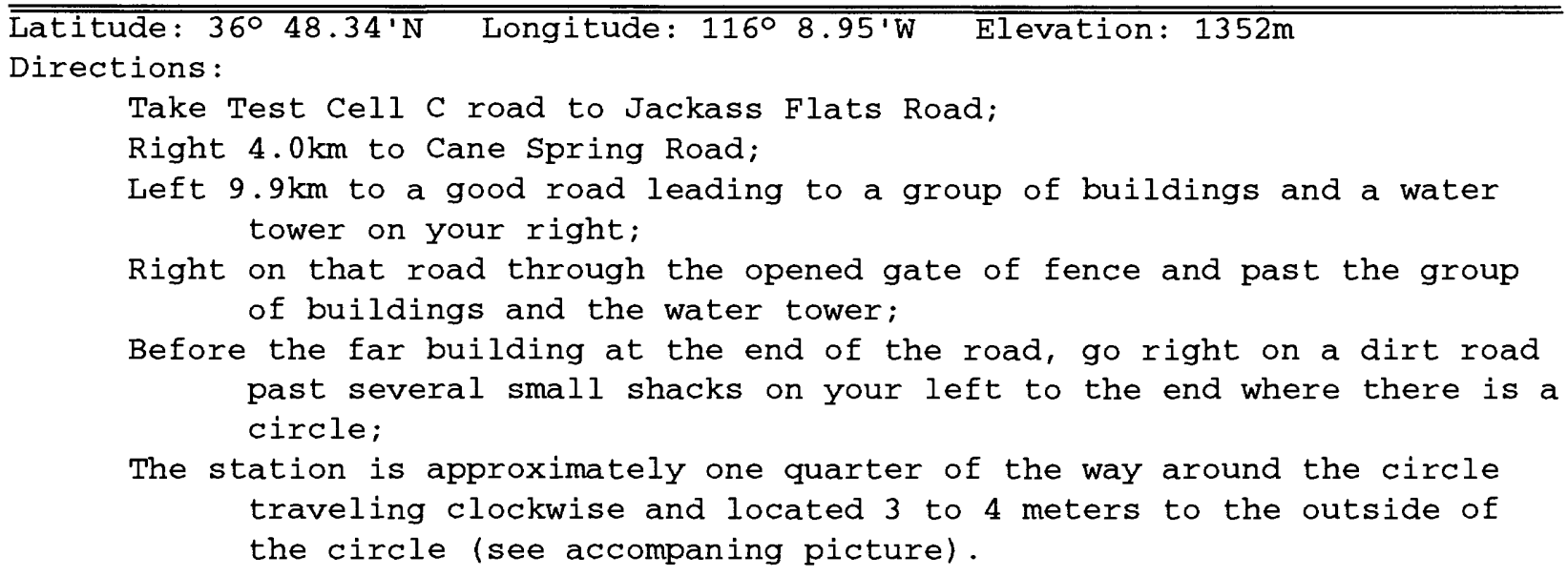

The station is approximately one quarter of the way around the circle traveling clockwise and located 3 to 4 meters to the outside of the circle (see accompaning picture).

General geology:

Unconsolidated to moderately cemented slope wash and stream bed

deposits.

\section{STATION SUMMARY :}

\begin{tabular}{|c|c|c|c|c|c|}
\hline OPERATION (UTC) & RECORDER & $\underline{\mathbf{S N}}$ & SEISMOMETER & $\underline{S N}$ & ORIENTATION \\
\hline $2131-194+2130$ & & 18 & & 700 & \\
\hline
\end{tabular}

\begin{tabular}{|c|c|c|c|c|c|c|c|c|}
\hline \multicolumn{3}{|c|}{ RECORD ON (UTC) } & \multicolumn{3}{|c|}{ RECORD OFF (UTC) } & \multicolumn{3}{|c|}{ EILTERS } \\
\hline TIME & $\underline{\mathrm{CC}}$ & $\underline{M C}$ & TIME & $\underline{\mathrm{CC}}$ & $\underline{M C}$ & GAIN & $\underline{\text { HI }}$ & $\underline{\underline{I O}}$ \\
\hline $182+2131$ & $\mathbf{R}+14$ & 9523 & & & & $90 \mathrm{db}$ & 5 & 10 \\
\hline $183+2249$ & C? & & & & & $84 \mathrm{db}$ & $"$ & $"$ \\
\hline \multirow{2}{*}{\multicolumn{2}{|c|}{ COMMENT: }} & Changed & gain due & o win & con & Lons. & & \\
\hline & & & $184+1849$ & $c-18$ & 9523 & $"$ & $"$ & $"$ \\
\hline $184+1918$ & $\mathbf{R}+8$ & $"$ & $185+2103$ & $\mathbf{C}+98$ & $"$ & $"$ & $"$ & $"$ \\
\hline
\end{tabular}

COMMENT ON: Reset clock to account for leap second a 182+23:9:60.

COMMENT ON: Modified MEQ to record 24 hour translation.

\begin{tabular}{|c|c|c|c|c|c|c|c|c|}
\hline $185+2116$ & $\mathbf{R}+16$ & $"$ & $186+1922$ & $C+43$ & 9227 & $90 \mathrm{db}$ & $"$ & " \\
\hline $186+1930$ & $\mathbf{R}+9$ & 9227 & $187+2030$ & $c-36 ?$ & 9523 & $"$ & $"$ & $"$ \\
\hline CON & ENT OF & $\mathrm{CC}$ & integrit & quest & ionabl & MVR & $\log$ & $187+2245)$ \\
\hline 45 & $R+60 ?$ & 9523 & $188+0157$ & +74 & 9227 & " & " & $"$ \\
\hline
\end{tabular}

COMMENT ON: CC's integrity questionable (see MVR log a 187+2245).

COMMENT OFF: Returned to check the $\mathrm{CC}_{\text {on }}$ since the power on MC9523 was

COMMENT OFF: low, but found the MEQ not translating.

COMMENT OFF: Therefore, we removed the MEQ for repairs.

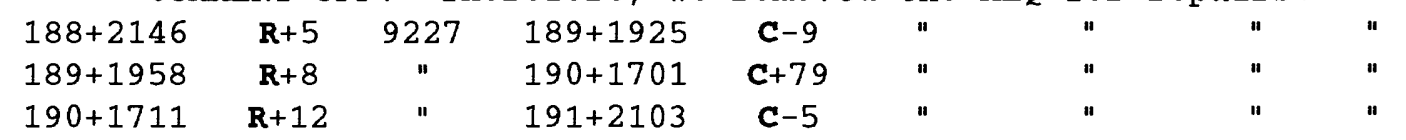

COMMENT OFF: Analog record full, drum rotation stopped a $191+1901$.

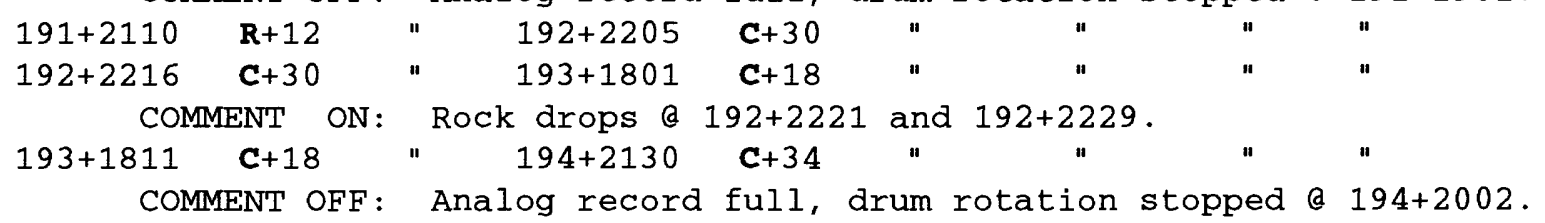

END RECORD TCT \& $194+2130$ UTC 


\begin{abstract}
Latitude: $36^{\circ} 43.37^{\prime} \mathrm{N} \quad$ Longitude: $116^{\circ} 7.74^{\prime} \mathrm{W}$ Elevation: $1158 \mathrm{~m}$
Directions :

Take Test Cell C road to Jackass Flats Road;

Right $21.1 \mathrm{~km}$ to road for Area 27 ;

Left $4.8 \mathrm{~km}$ to an old grown-up 4 wd drive trail on the left;

Left on the 4wd trail and drive toward the closest grey/white mound to the NNW until the road ends at a dry stream bed;

The station is on top of the whittish-grey mound NNW across the creek

(about a 4 or 5 minute walk; (see accompaning pictures).

General geology:

Unconsolidated to moderately cemented flood plain and stream bed

deposits. Locally (at the station site) sedimentary and tuffaceous

sedimentary rocks.
\end{abstract}

STATION SUMMARY:

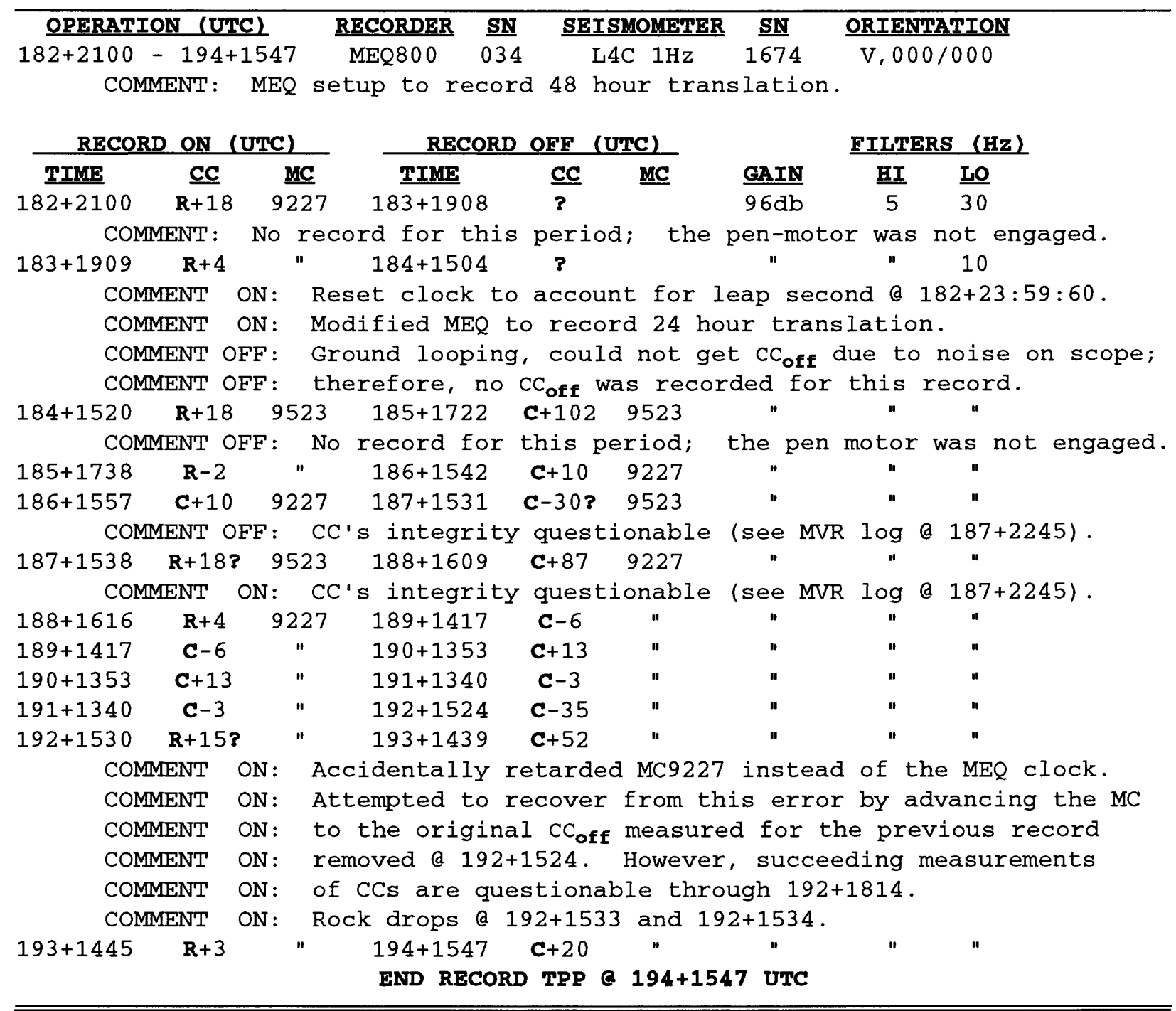




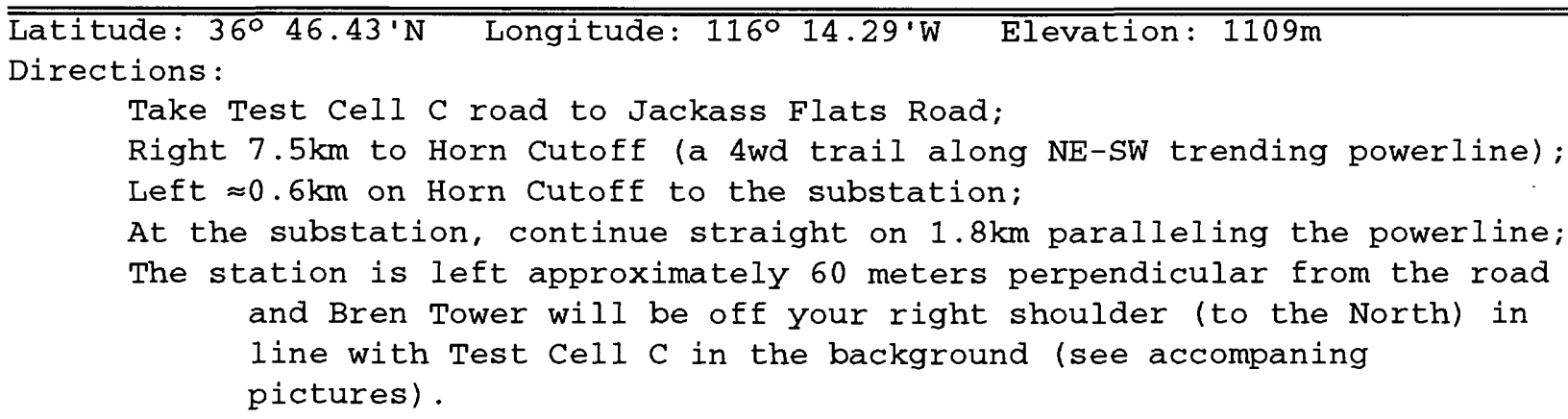

STATION SUMMARY :

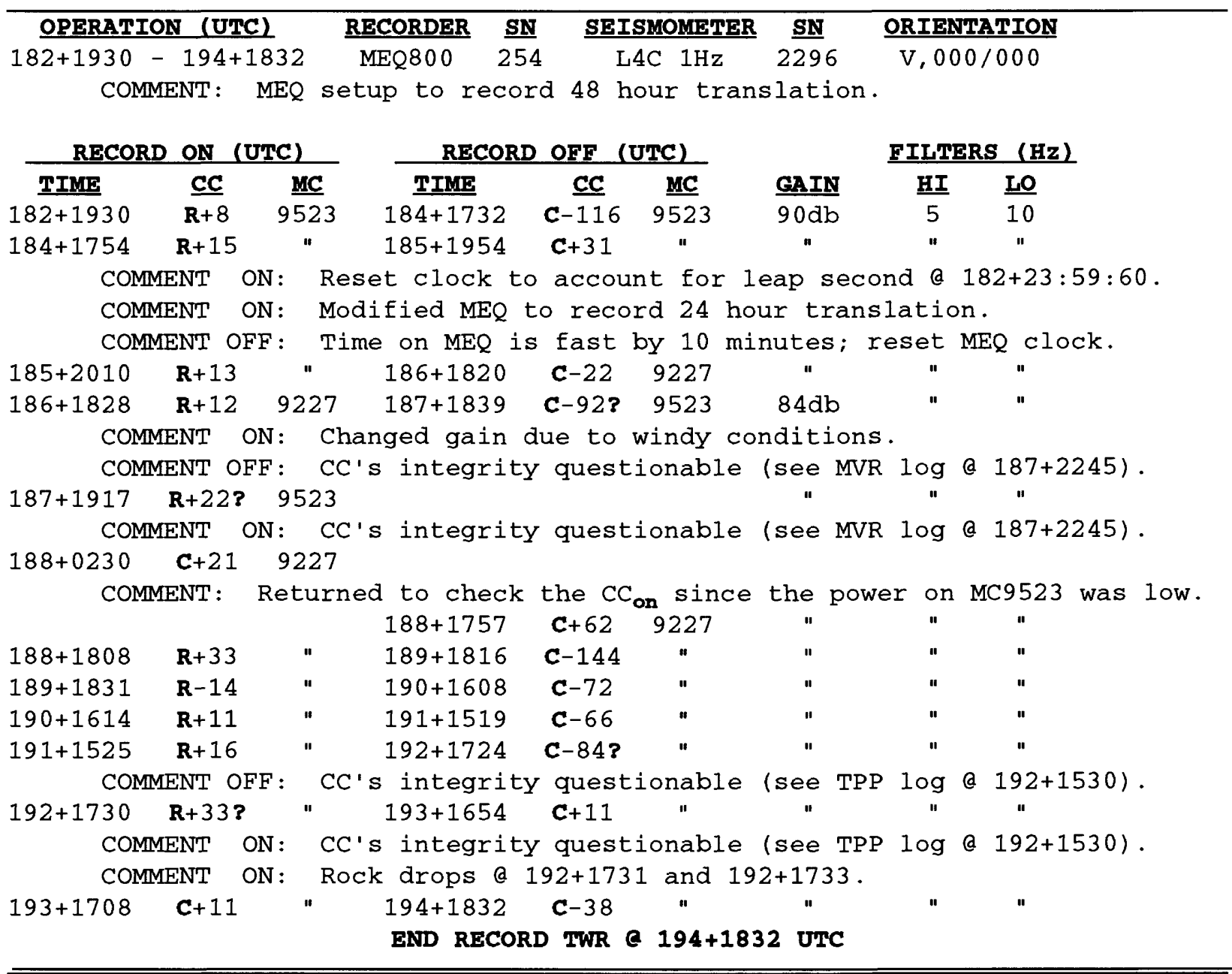


Station Summaries of DR200 Instruments 

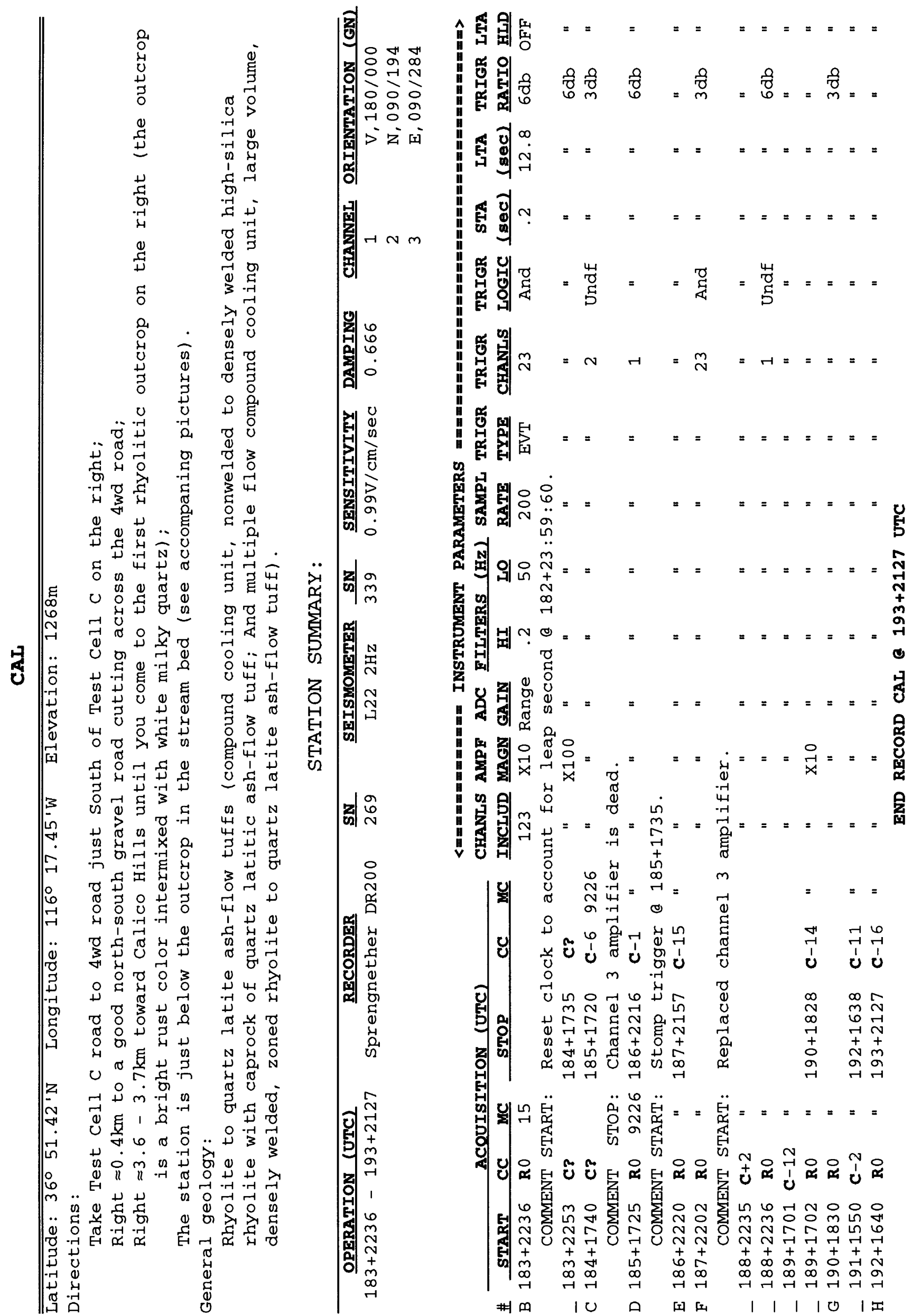


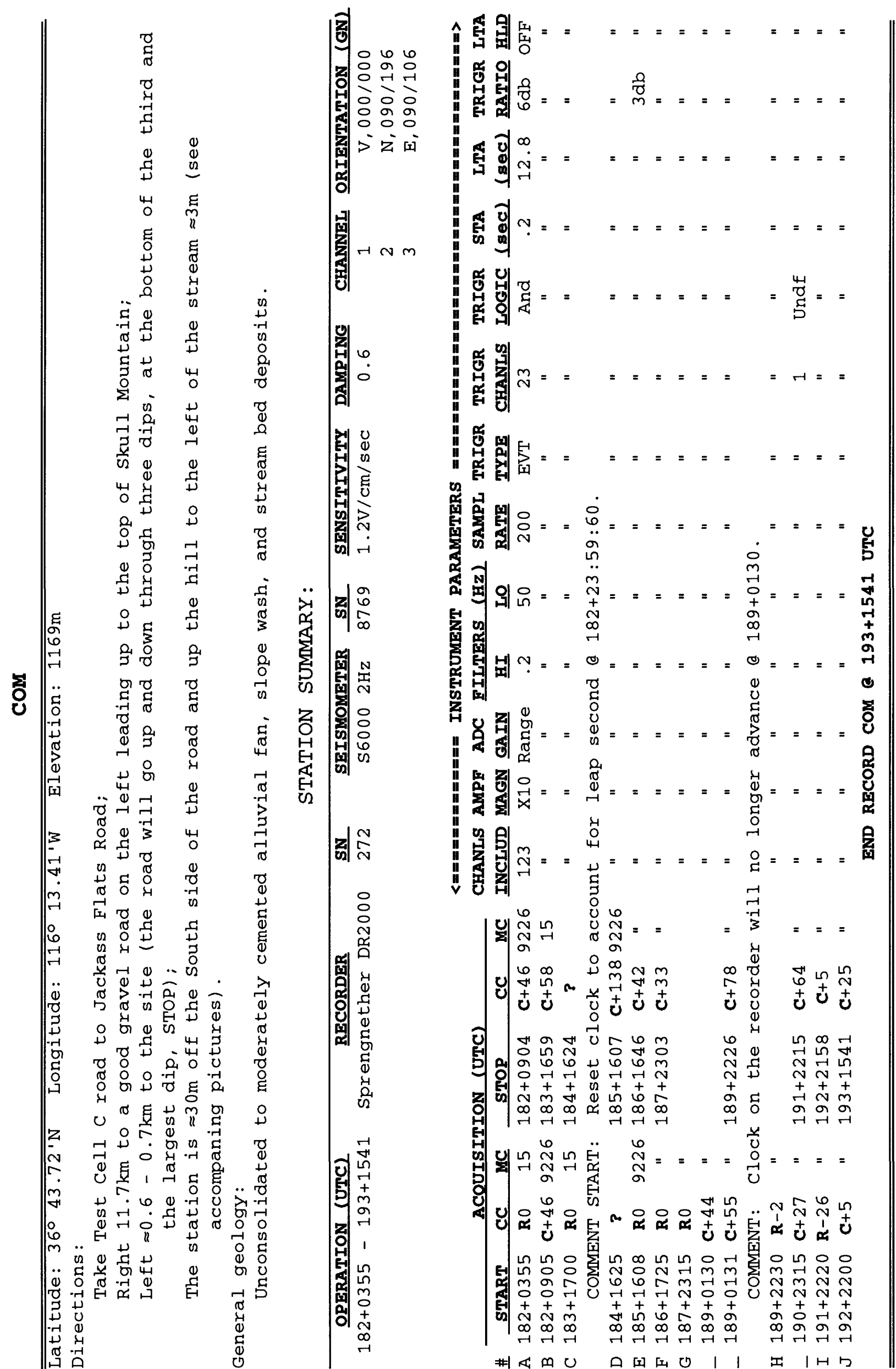




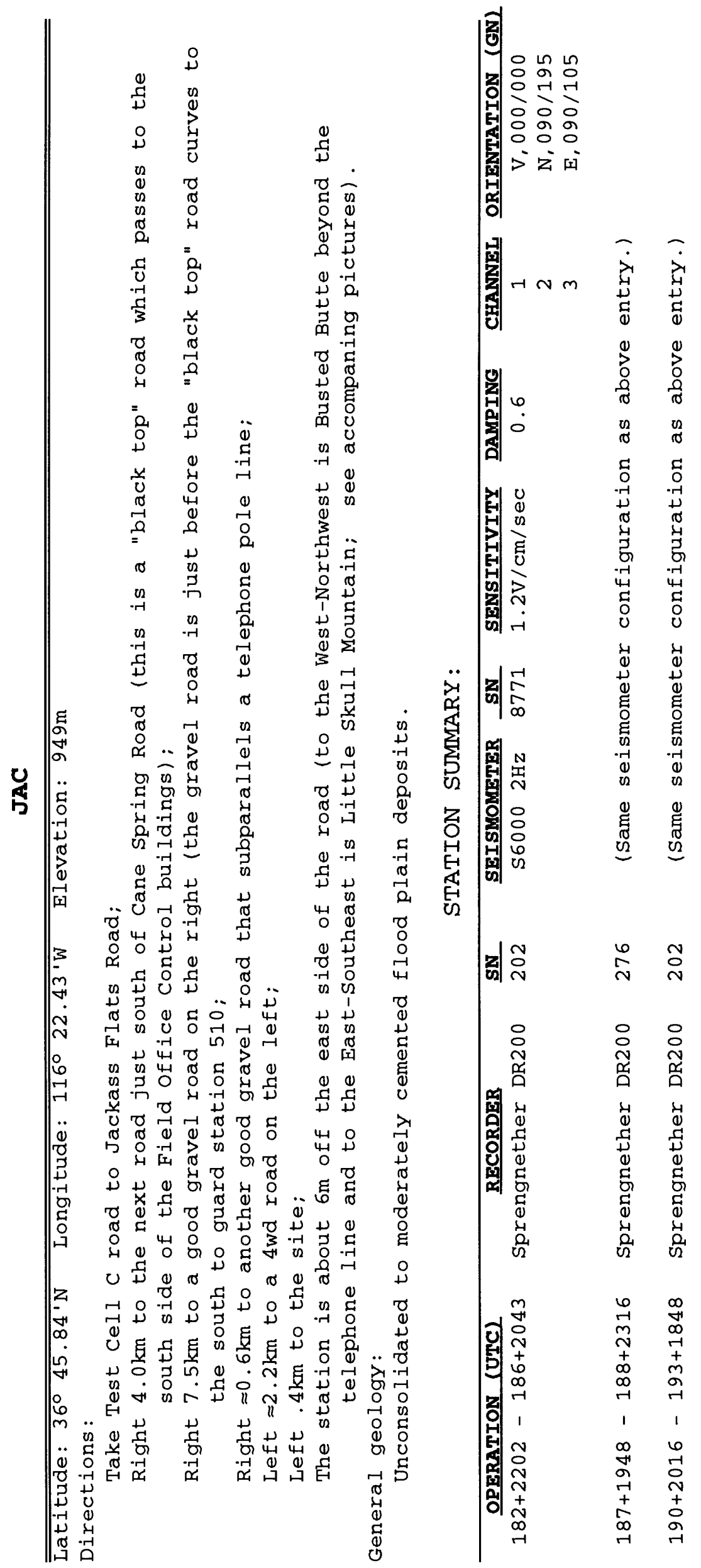




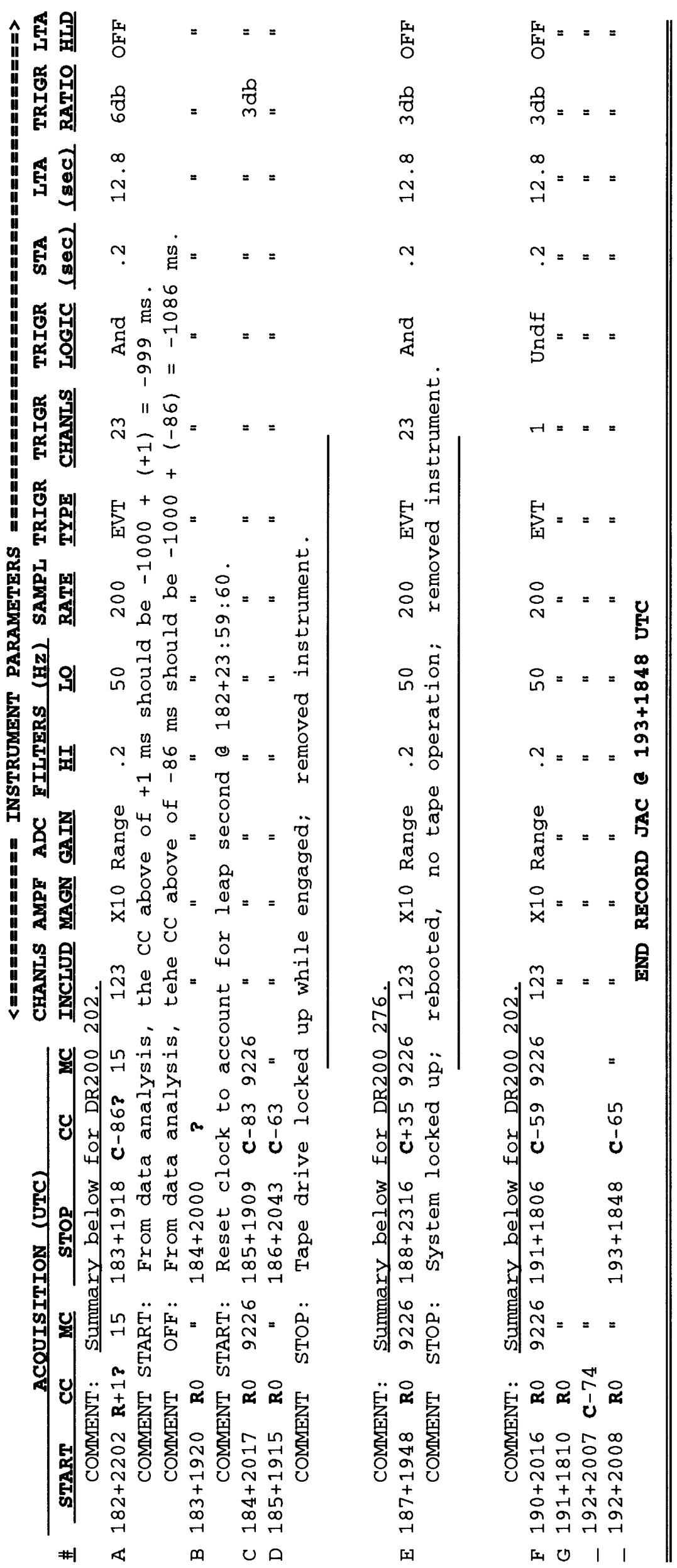




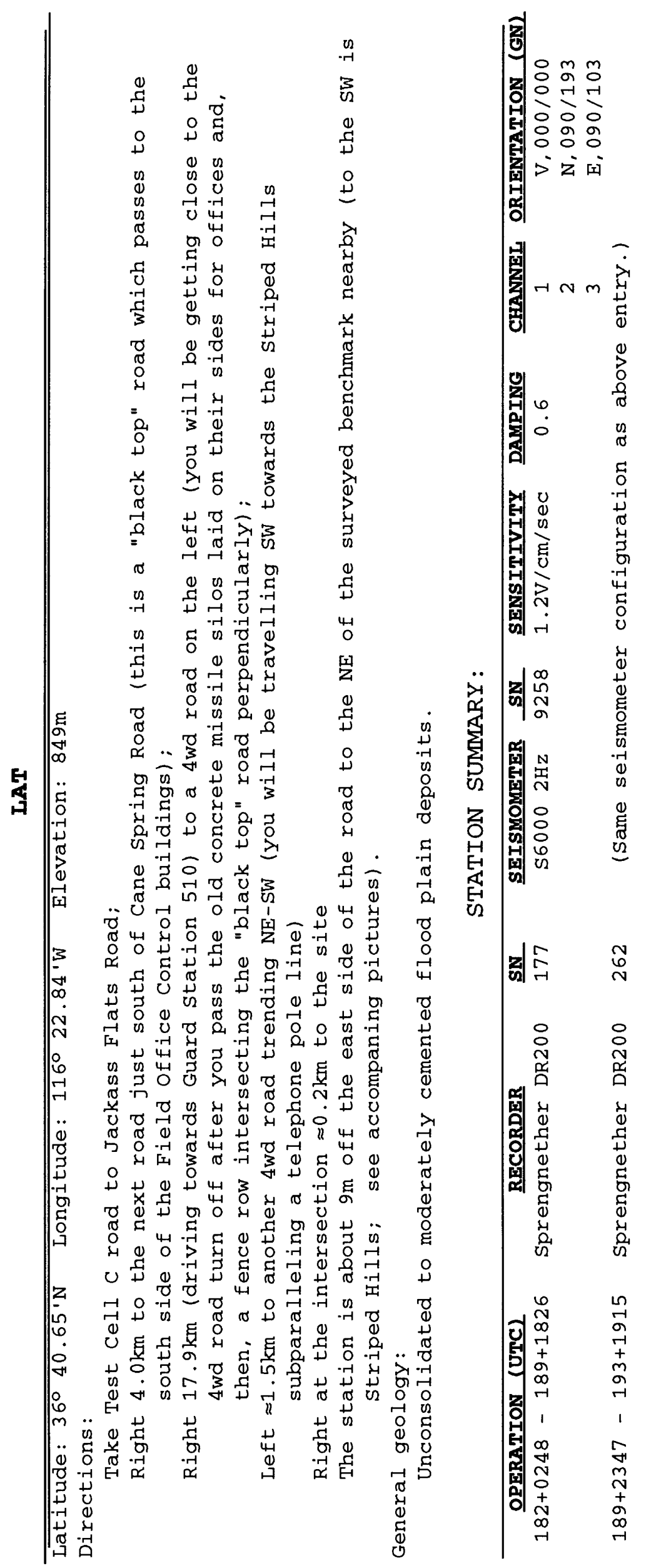




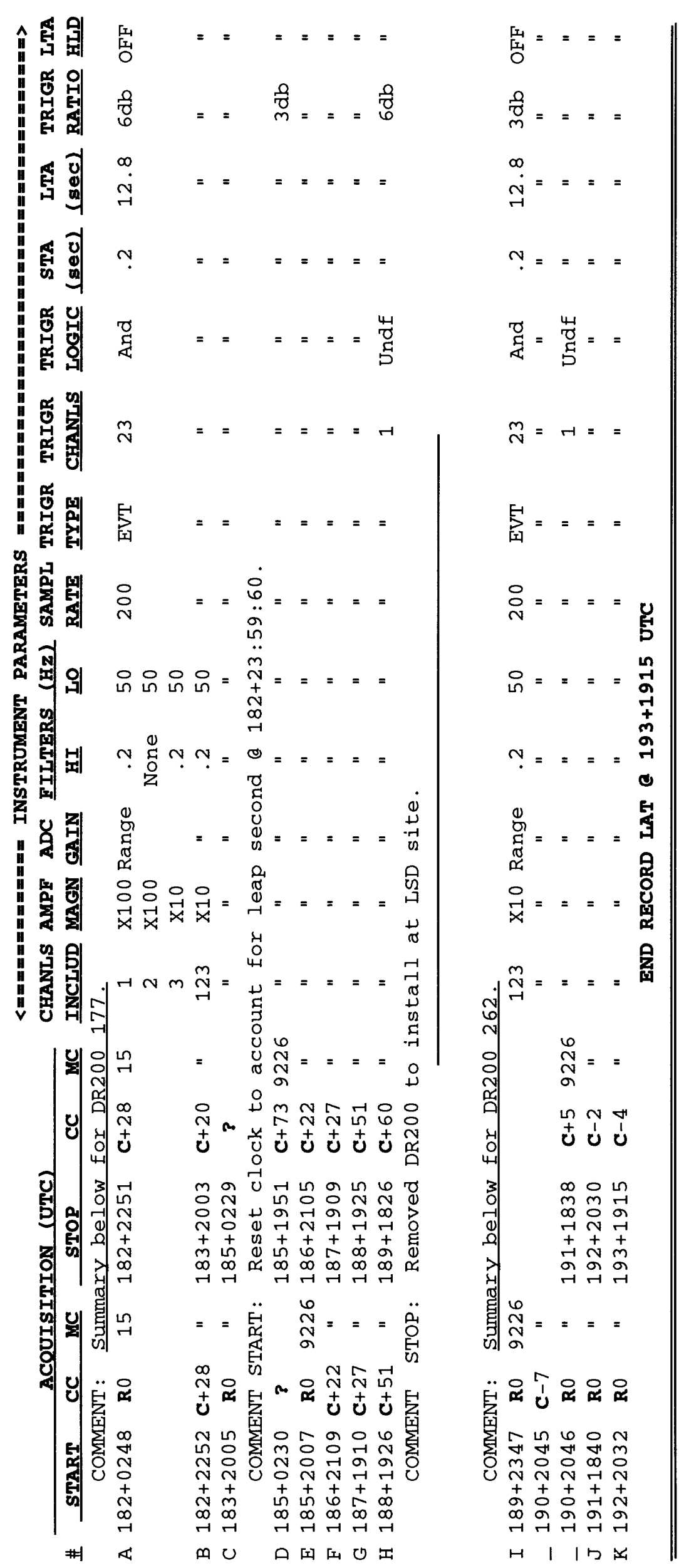




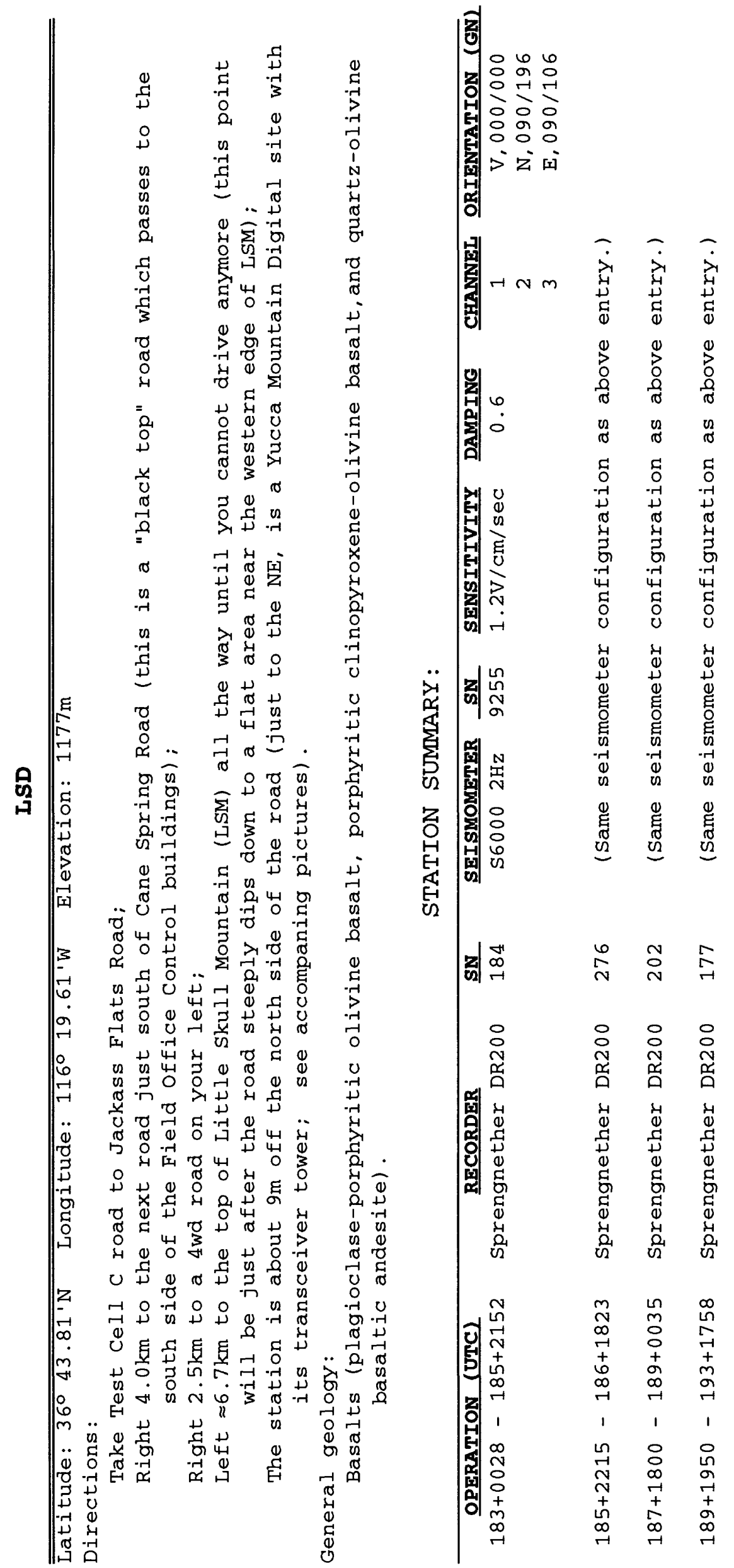




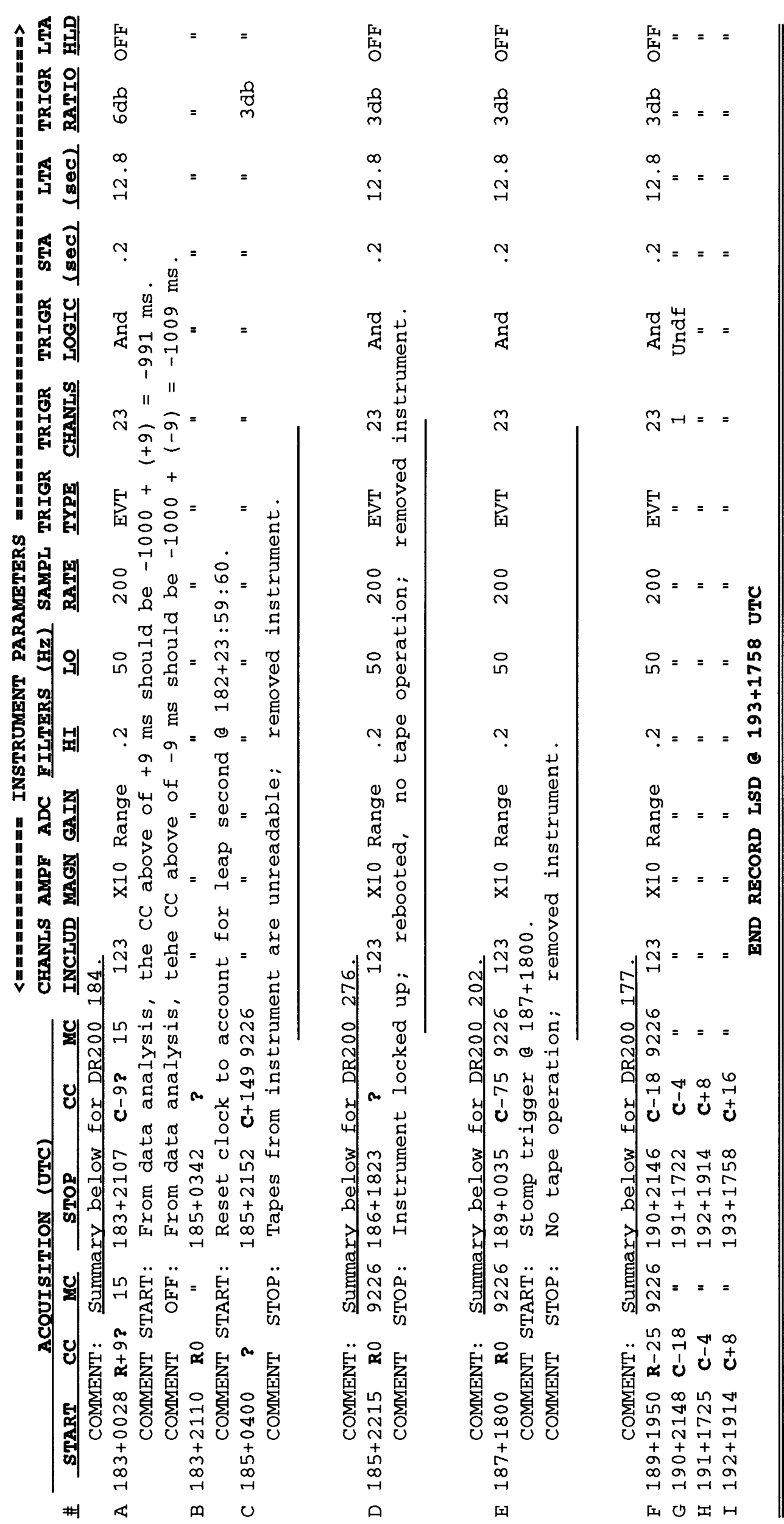




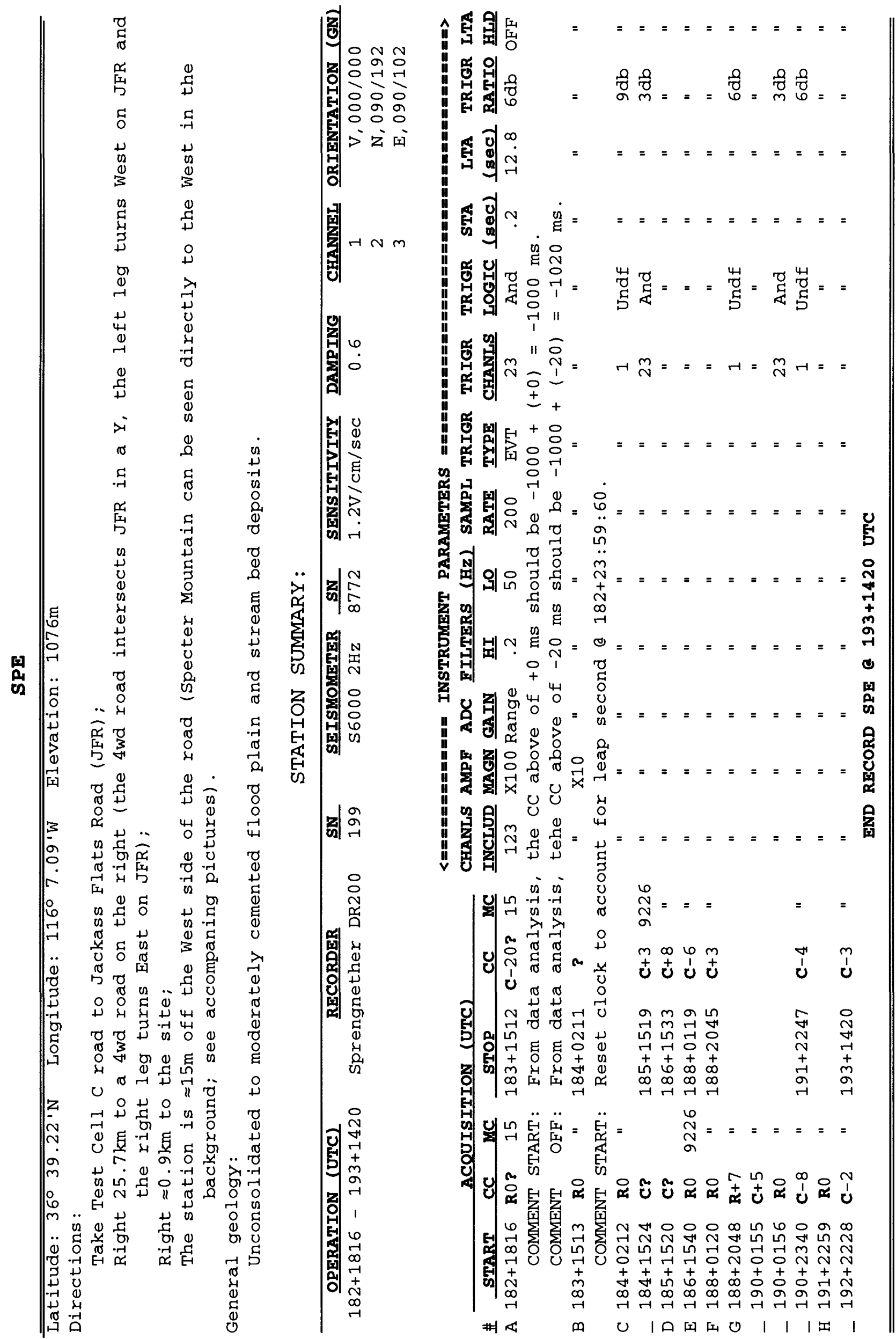




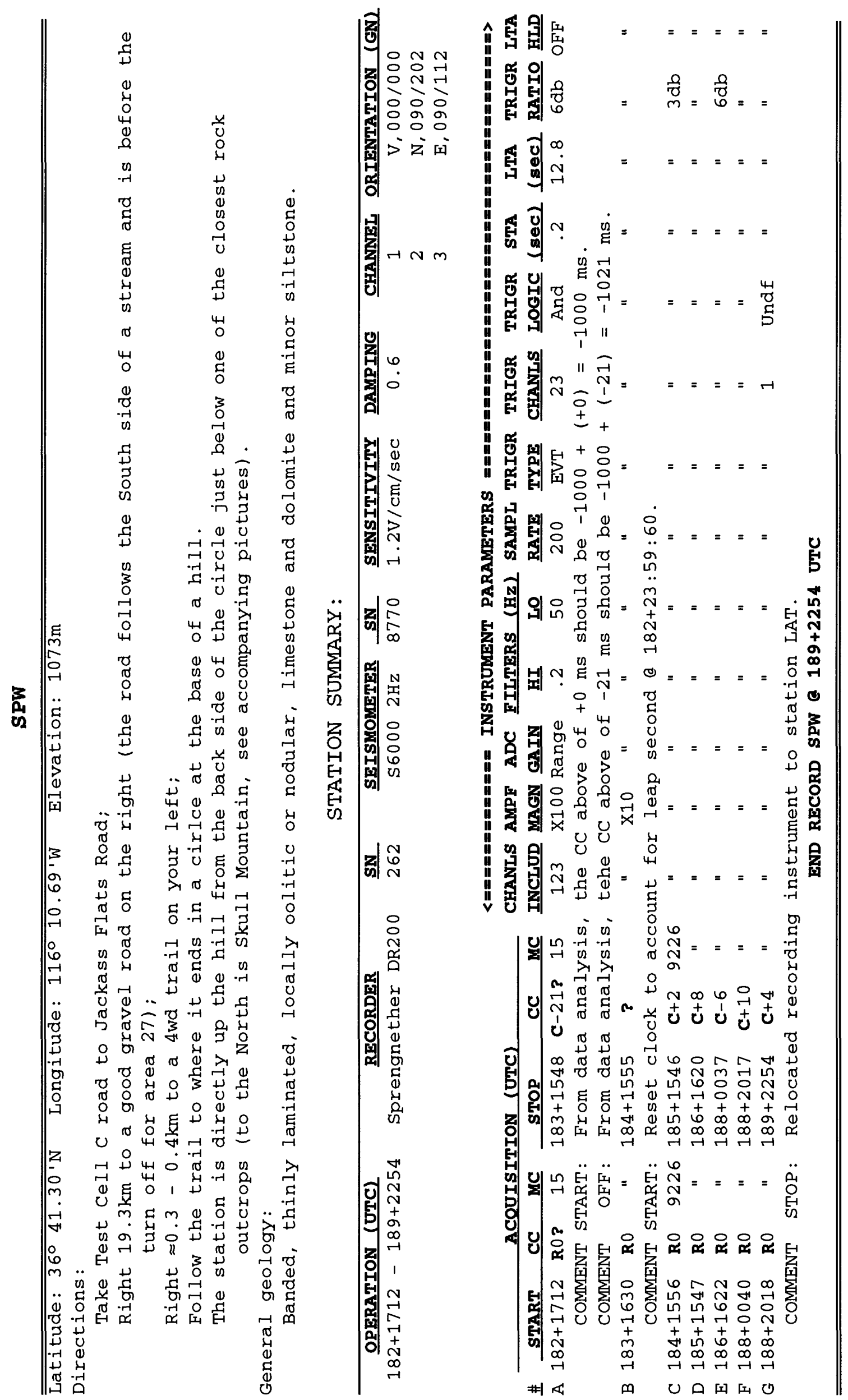




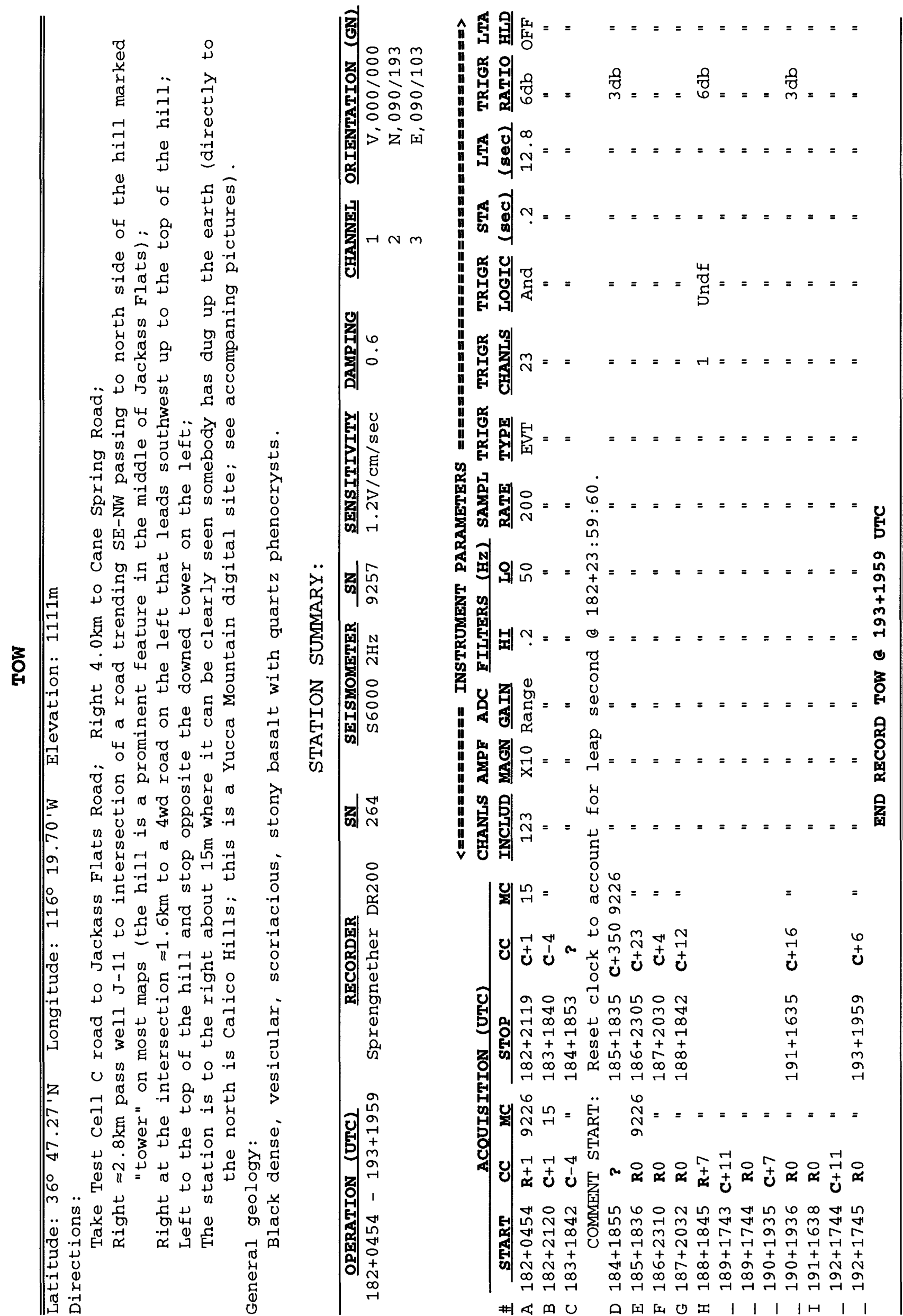

$m$ 
Station Summaries of REFTEK Instruments 


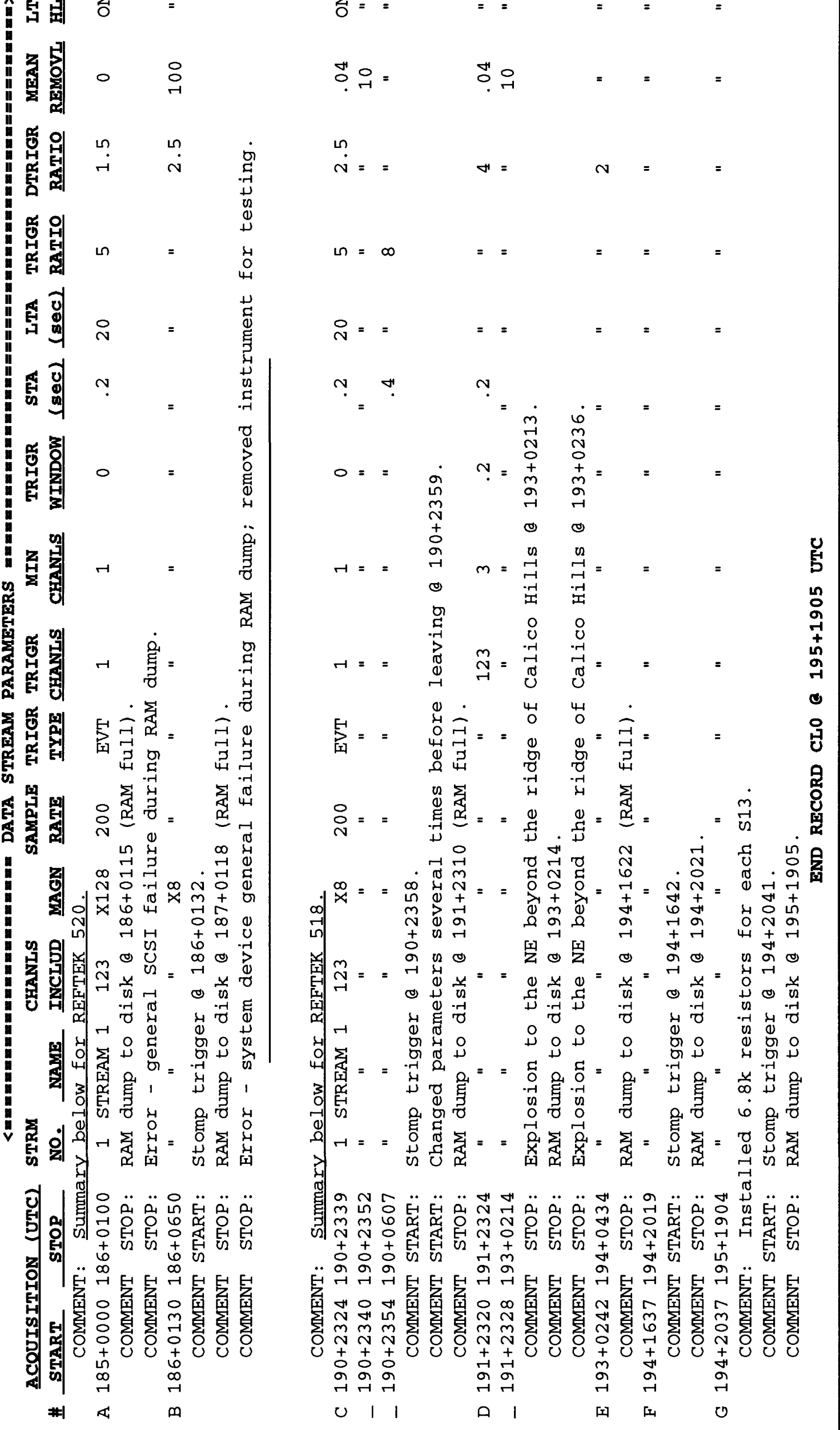




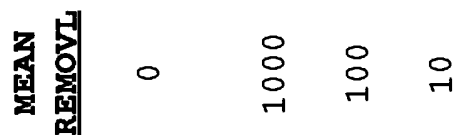

in.

1.

.

1

.

I

-

...

$\therefore$

II

-

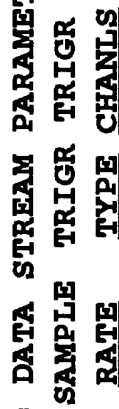

$\rightarrow$ 号号.

$\therefore \quad$ त्र

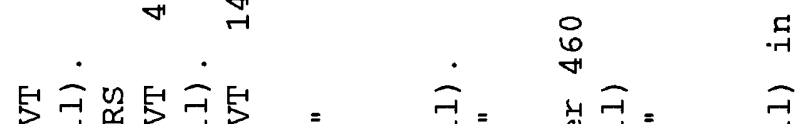

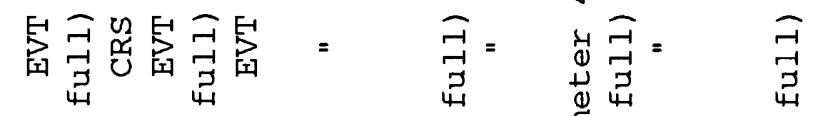

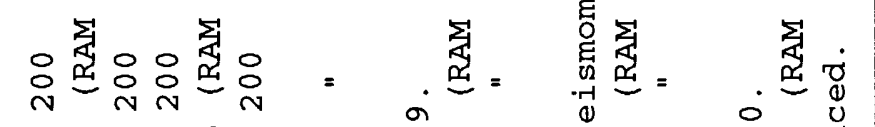

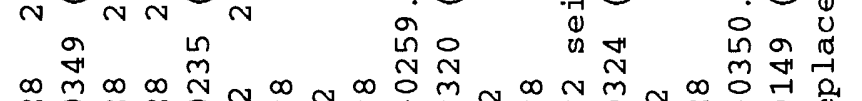

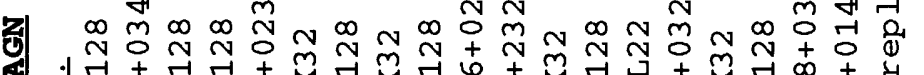

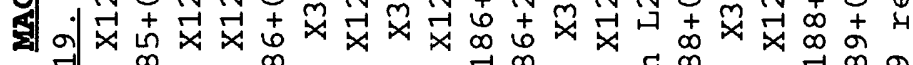

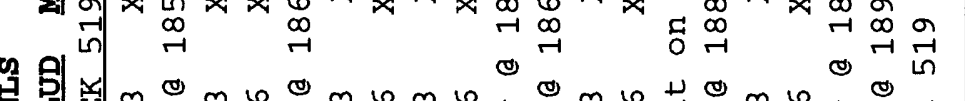

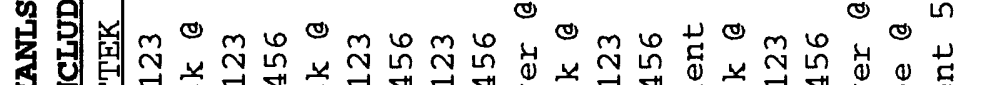

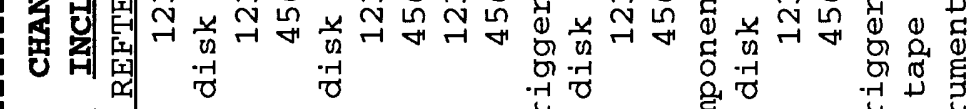

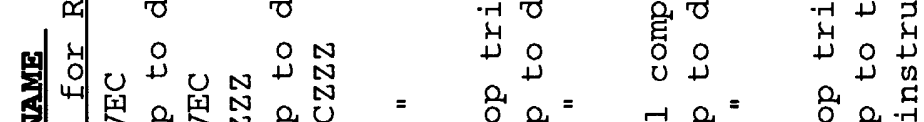

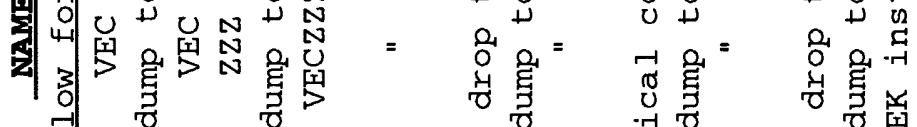

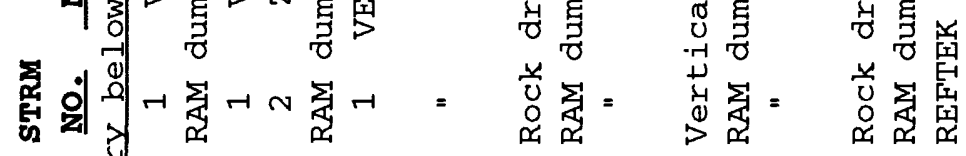

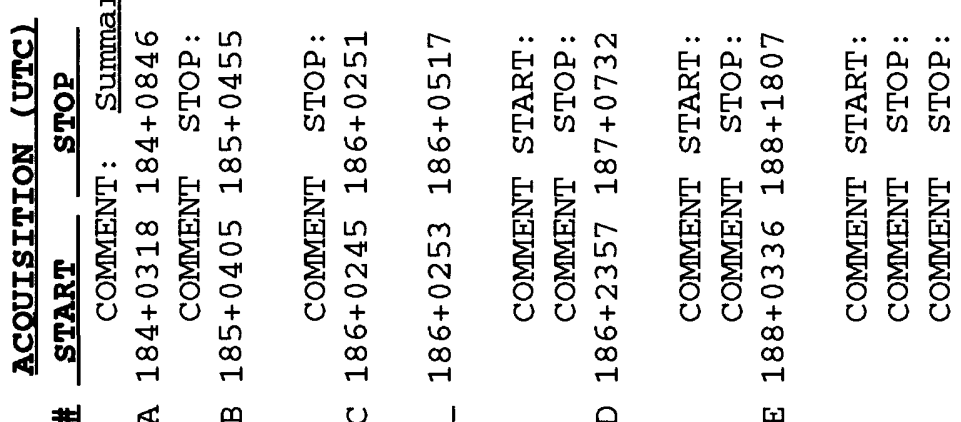




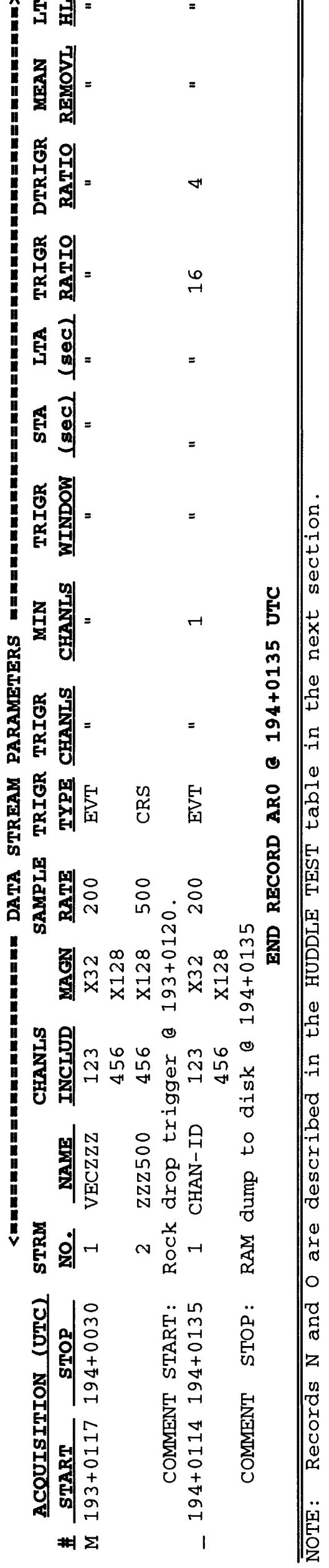


Station Summaries of the HUDDLE Test 


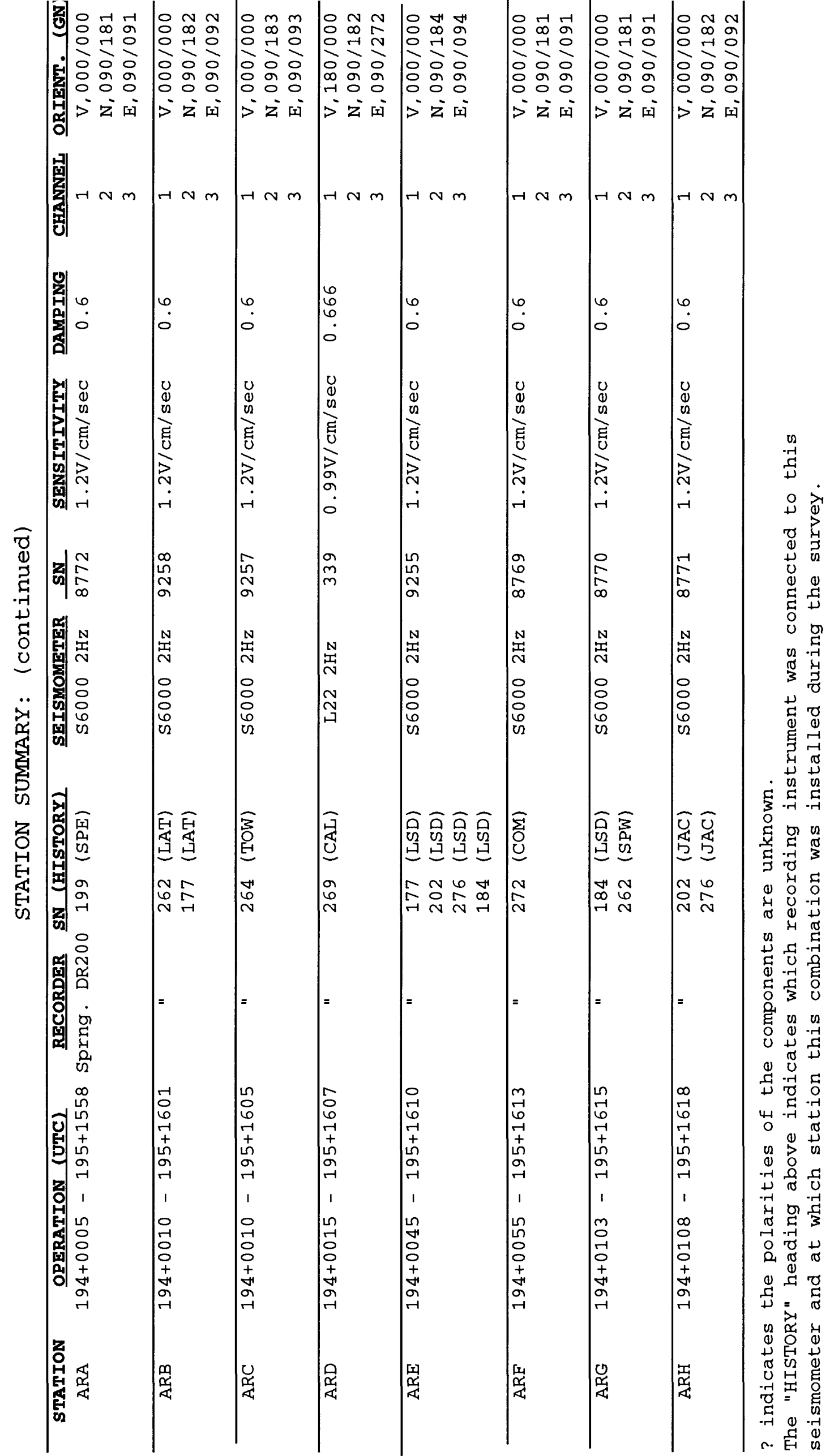




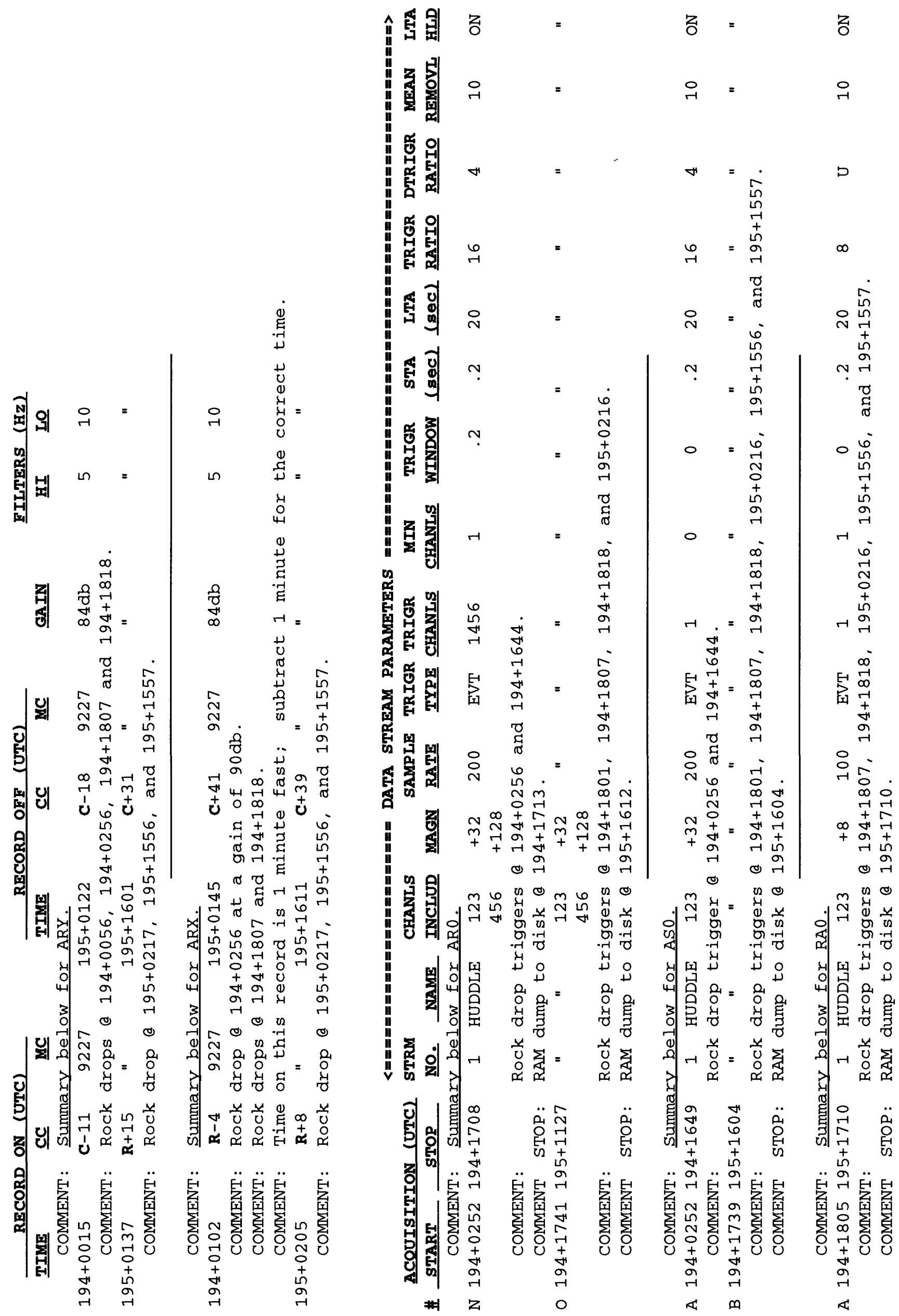




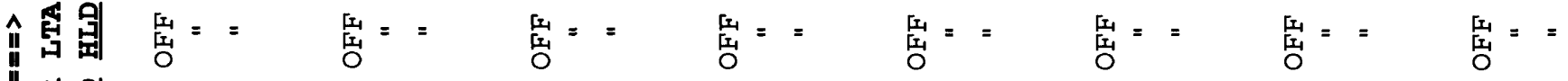

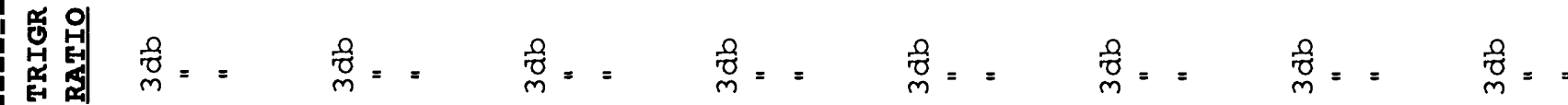

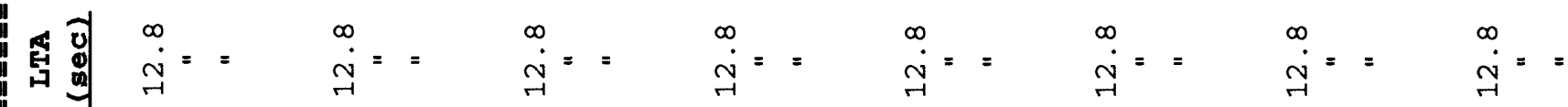

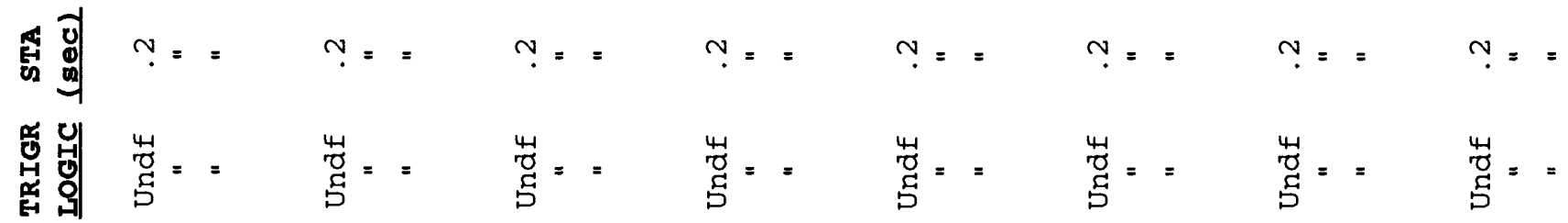

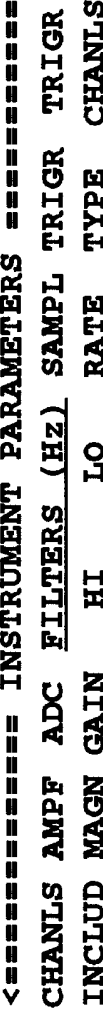

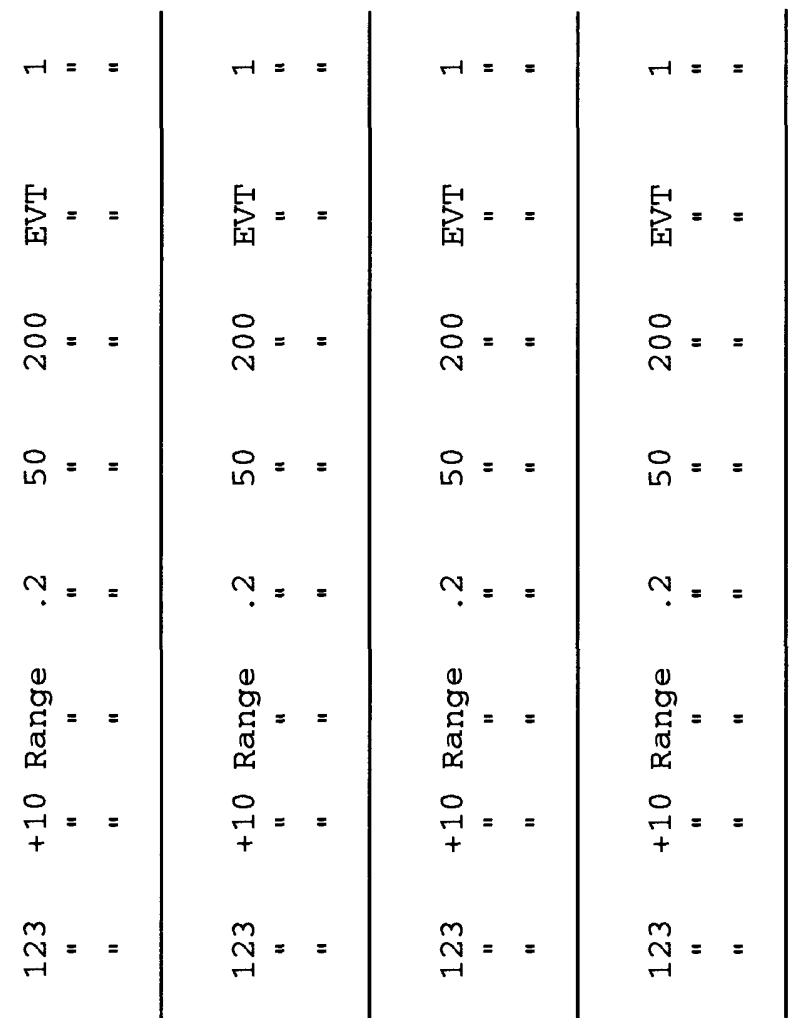

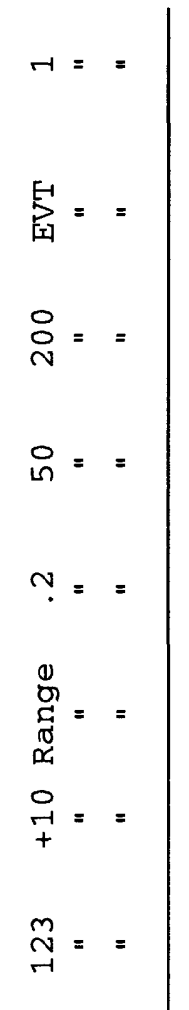

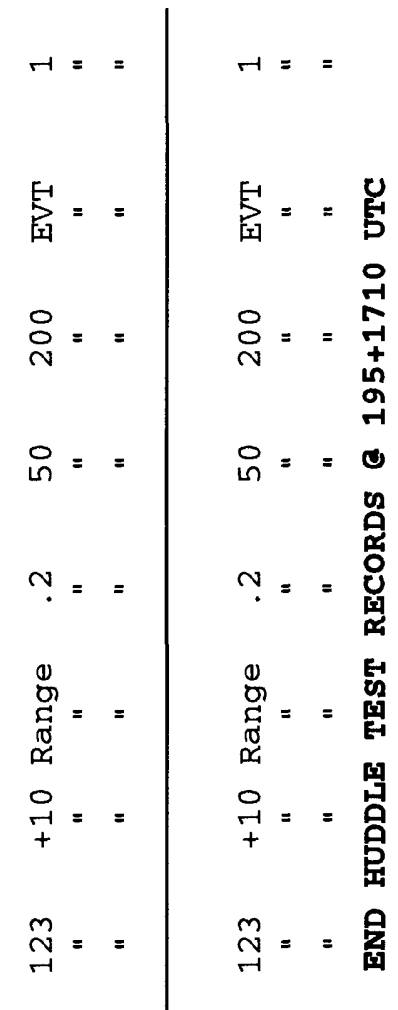
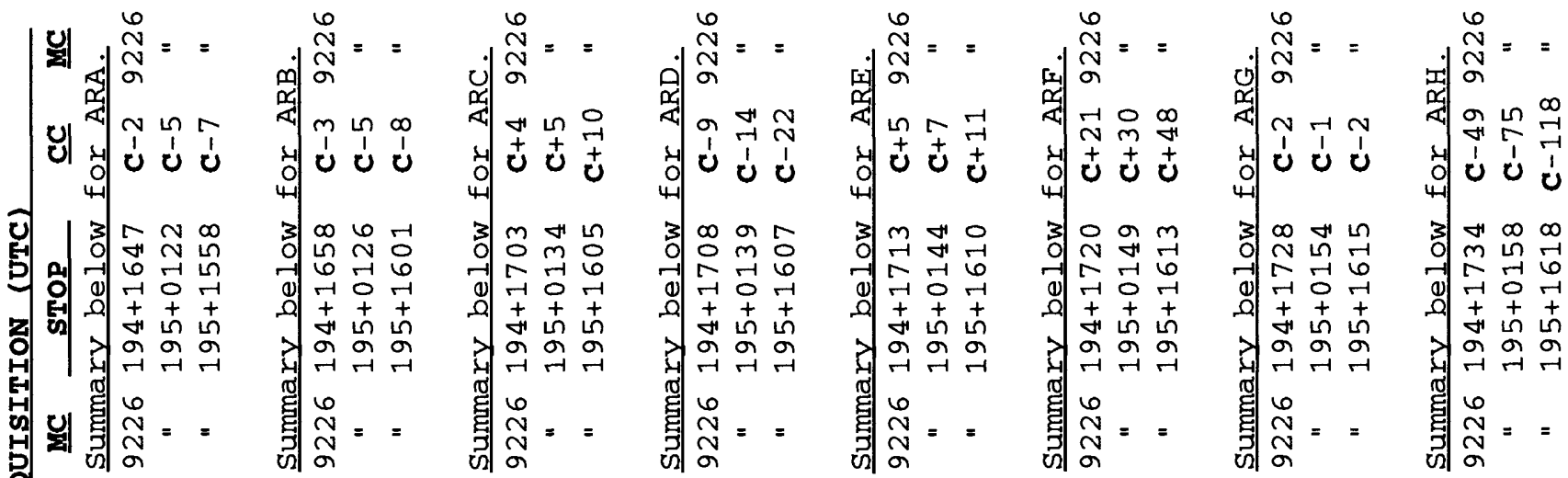

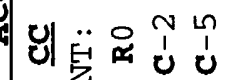

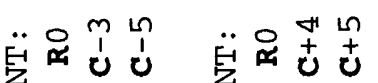

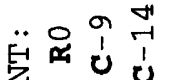

$\ddot{4}$ 뉸

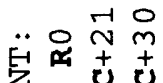

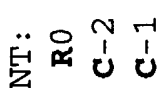

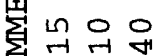

진은

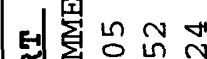

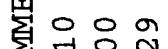

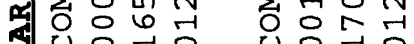
E⿹ $+t+t$ o क क $+4$ बूँ or $+7$ बूa 일

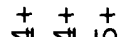
कू नेन ने ने

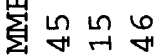
वी 엉 of

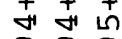
ने ने ने 《ा

in in o $\sum^{3}$ in $00 \pi$

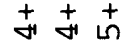
का का का न न न ब $\sum_{1} m o n$ 虽 $+t+$ क के न न ब

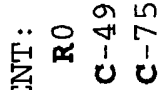

$\sum_{i}^{1} \infty \mathrm{m} 0$

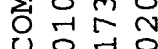
$+t+$ or or o

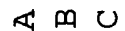




\section{Appendix B}

Clock Summary of the Master Clock Instruments 
Clock Corrections (CC) for Master Clocks (MC)

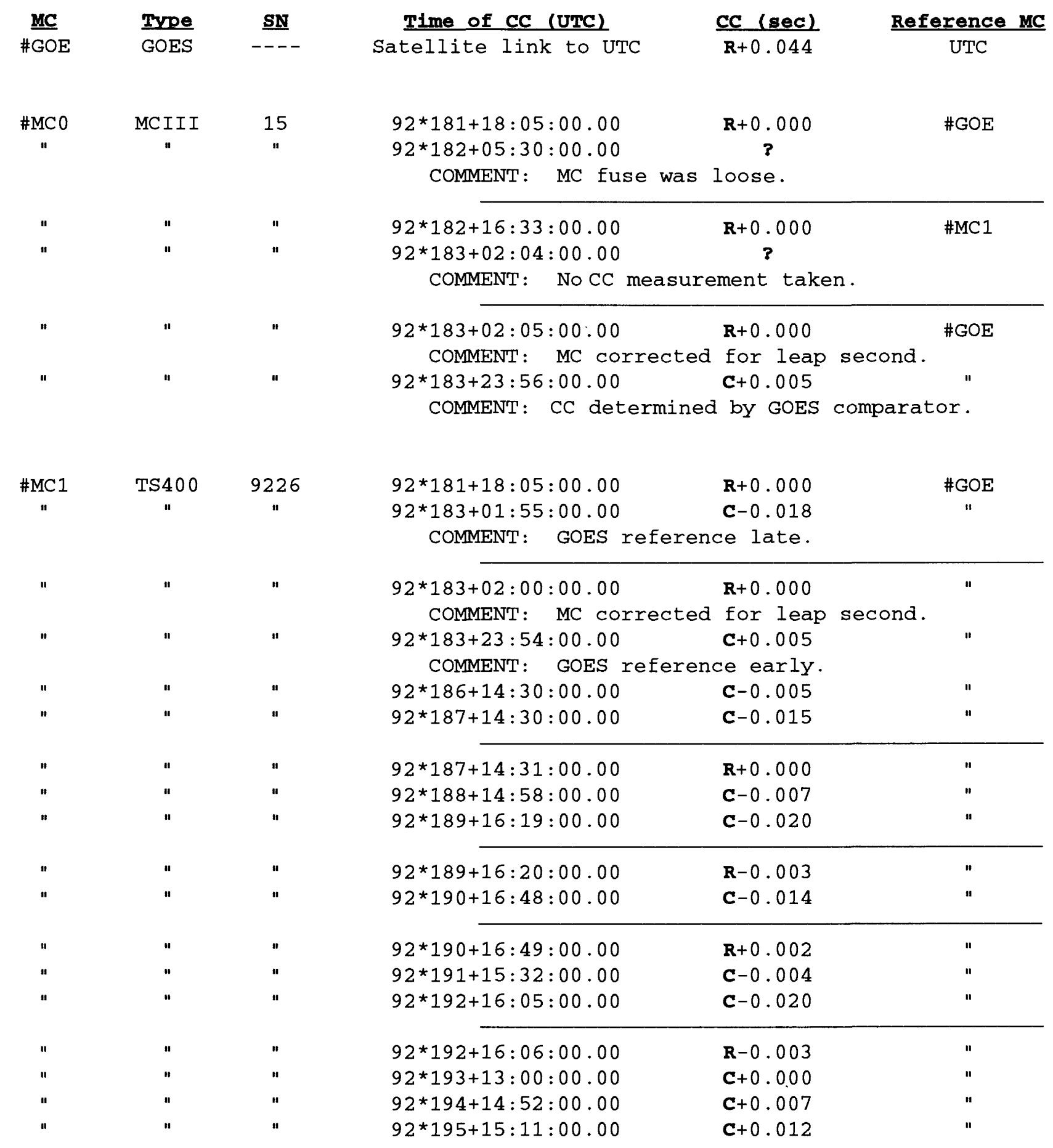


Clock Corrections (CC) for Master Clocks (MC) -- continued

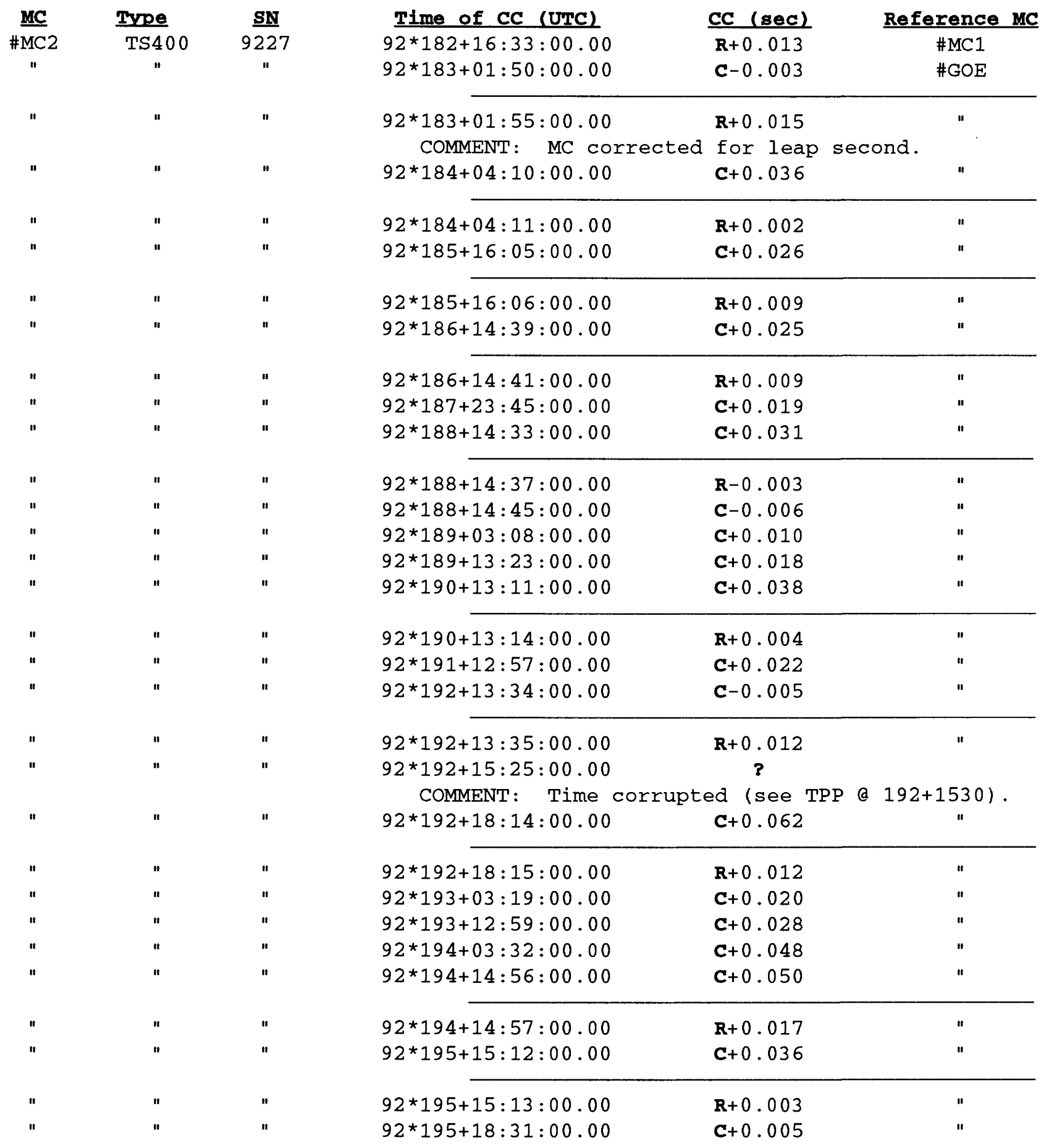


Clock Corrections (CC) for Master Clocks (MC) -- continued

$\begin{array}{ccc}\text { MC } & \text { Type } & \text { SN } \\ \text { "MC3 } & \text { TS400 } & 9523 \\ \text { " } & \text { " } & \text { " } \\ \text { " } & \text { " } & \text { " } \\ \text { " } & \text { " } & \text { " } \\ \text { " } & \text { " } & \text { " } \\ \text { " } & \text { " } & \end{array}$

\begin{tabular}{|c|c|c|}
\hline Time of CC (UTC) & CC $(s e c)$ & rence $\mathrm{MC}$ \\
\hline $92 * 182+16: 33: 00.00$ & $\mathbf{R}+0.003$ & \#MC1 \\
\hline $92 * 183+01: 47: 00.00$ & $\mathbf{c}-0.010$ & $\# \mathrm{GOE}$ \\
\hline $92 * 183+02: 06: 00.00$ & $\mathbf{R}+0.008$ & $"$ \\
\hline $\begin{array}{c}\text { COMMENT: } \text { MC corrected } \\
92 * 184+04: 03: 00.00\end{array}$ & $\begin{array}{l}\text { For leap second. } \\
\text { c+0.034 }\end{array}$ & " \\
\hline $92 * 184+04: 05: 00.00$ & $\mathbf{R}+0.016$ & $"$ \\
\hline $92 * 185+16: 08: 00.00$ & $\mathbf{c}+0.046$ & $"$ \\
\hline $92 * 185+16: 10: 00.00$ & $\mathbf{R}+0.013$ & $"$ \\
\hline $92 * 187+14: 30: 00.00$ & $c+0.014 ?$ & " \\
\hline
\end{tabular}

$92 * 187+14: 30: 00.00 \quad C+0.014$ ?

COMMENT: Discoverd low charge on MC's battery COMMENT: while servicing station MVR. COMMENT: (see MVR \& 187+2245).

$92 * 187+23: 22: 00.00 \quad$ C+13.039

\#MC2 COMMENT: CC after MC lost its charge.

$92 * 189+02: 46: 00.00 \quad \mathrm{C}+12.933 \quad "$ COMMENT: CC after MC charged for 24 hours.

\begin{tabular}{lll}
$92 * 189+03: 15: 00.00$ & $\mathbf{R}+0.014$ & \#GOE \\
$92 * 190+01: 09: 00.00$ & $\mathbf{C}+0.032$ & $"$ \\
\hline $92 * 190+01: 10: 00.00$ & $\mathbf{R}+0.015$ & $"$ \\
$92 * 191+01: 13: 00.00$ & $\mathbf{C}+0.035$ & $"$ \\
$92 * 191+01: 14: 00.00$ & $\mathbf{R}+0.002$ & $"$ \\
$92 * 192+01: 00: 00.00$ & $\mathbf{C}+0.022$ & $"$ \\
$92 * 192+01: 01: 00.00$ & $\mathbf{R}+0.006$ & $"$ \\
$92 * 193+03: 16: 00.00$ & $\mathbf{C}+0.029$ & $"$ \\
$92 * 194+03: 27: 00.00$ & $\mathbf{C}+0.051$ & \\
$92 * 194+03: 31: 00.00$ & $\mathbf{R}+0.002$ &
\end{tabular}




\section{Appendix C}

Copy of the Tape Labels (field logs) for DR200 Instruments

Tape labels compiled during the survey $\ldots \ldots \ldots \ldots \ldots \ldots \ldots \ldots \ldots$ p. . . . . . . . . . . . . 54

Tape labels compiled during the HUDDLE test $\ldots \ldots \ldots \ldots \ldots \ldots \ldots \ldots$ page 62 
GNing ON 121832236 MB TAPEA-no kegoxds degaussed OFF $\mathbf{m s}$ $x_{\rightarrow E}$

STACAL \#BA DR264 JUGe339-222

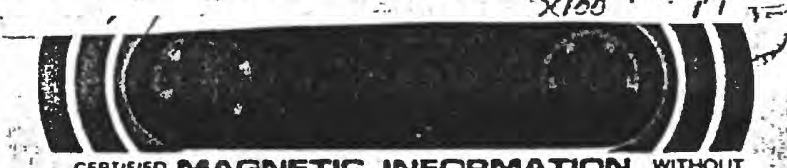

CEATIEO MACNETIC INFOAMATION

EVETEAMA
FAEE
431 DIGITAL CASSETTE ANSIECMAASO 300 fER

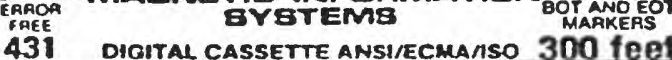

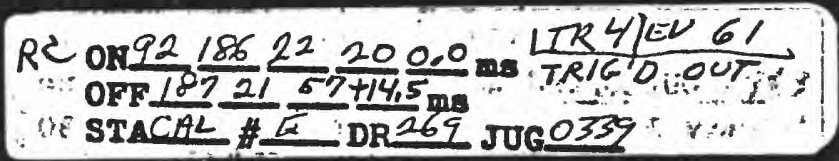

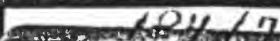

ON 42.7 HO 75 मे

OFF $185.1720+5.6 \mathrm{~ms}$

STACAL\# C DR 269 JUG $0339-\angle 22$

, 2,12,8, $\times 100$

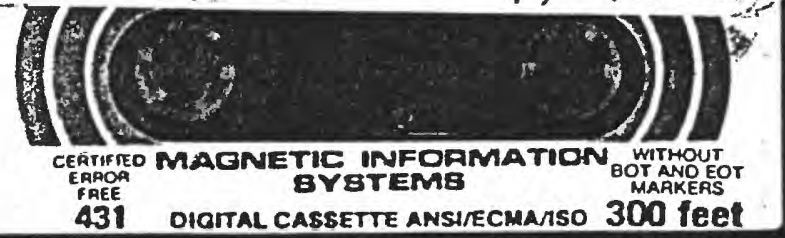

$0 x 9218722020.0$ TK215K 29:

OTF $1901828+14.4 \mathrm{~ms}$

82UCAL \#E DR269 JUG0339 <-22

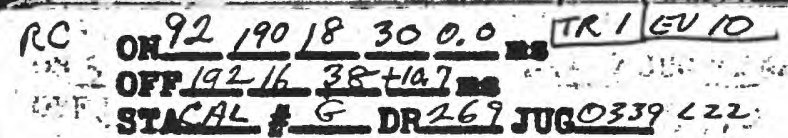

Reset to o $92 / 851725 \quad 0.0 \quad$ ITR 3|EV 42

besut tim I. $186.2216+0.7$

ACAL D $1269,10339-<22$

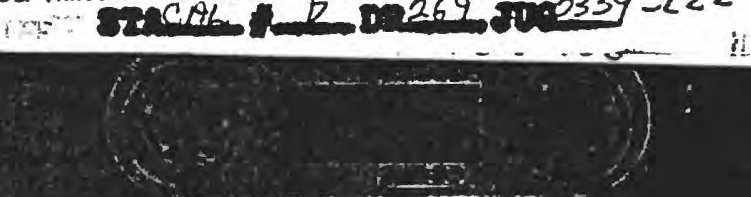

$H$ Here

Re or9219216400.0 ITRIIEVI

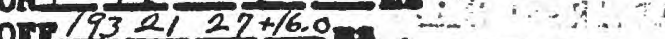

$0 \times 19=12+760$

STCAL 4 DR 269 J00 $0339<22$

$x+28$

T 300 $\mathrm{NH}$ 


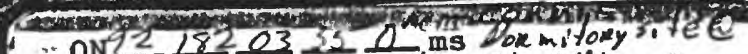

OFFB2 O4 04 $-45.6 \mathrm{~m}^{5400} 5 \mathrm{~km} 11 \mathrm{Mtn}$

OFI $A$ DR272 JUG 2764 EVNaER ह2GEV|riez

$H$

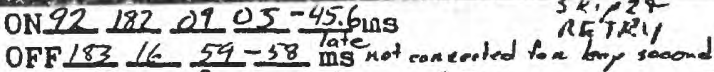

STACOM \#B DR272 JUG_8769 IIXI |TEV
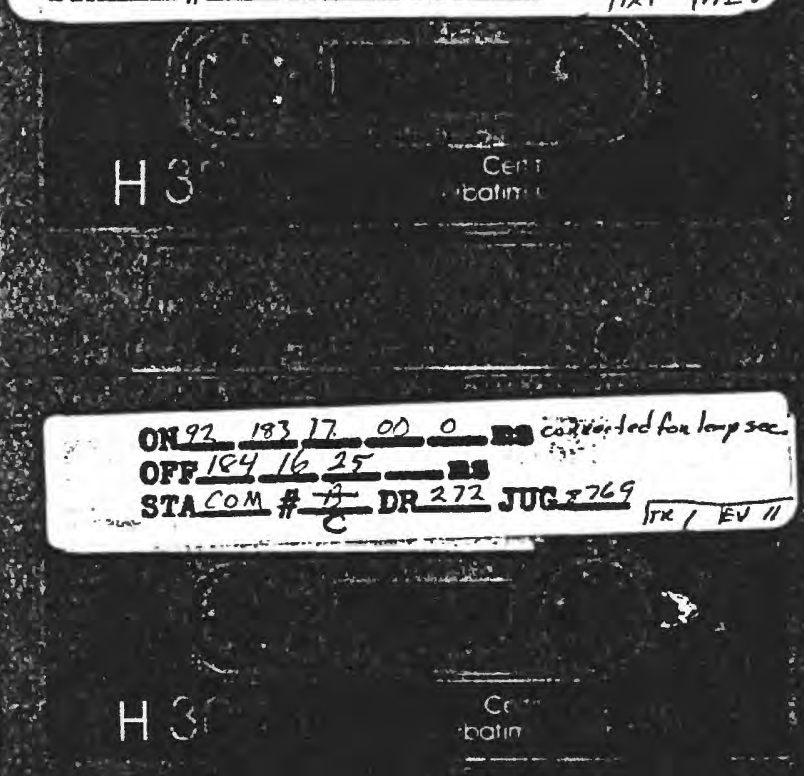

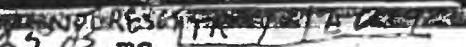
ON92 $18416 \times 3 \frac{13}{16} \mathrm{~ms}$

ON $\frac{92}{185} 16$, $2-138.2 \mathrm{~ms}$

ORT $\frac{185}{\operatorname{com}} \frac{16}{D} \frac{O^{2}-138^{2} \mathrm{~ms}}{D R 272}$ JUG $8769,6 \mathrm{~dB}, 12.8,10$

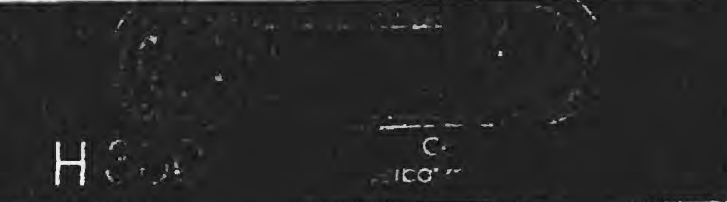

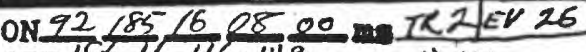

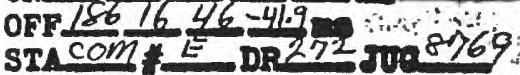

RC: 019218612 25 0.0 LTR 2 EV 30

if sit $1872303-33.4$.

$\therefore$ 82 COM E DR272 JuR8769

T 300NH

Certified by

Verbatim Corporaticr

\section{RC om $921872315+0.2$ ITR $3 \longdiv { L V ~ } 3 9$ $0.28922,26-78.2, \cdots$

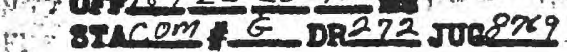

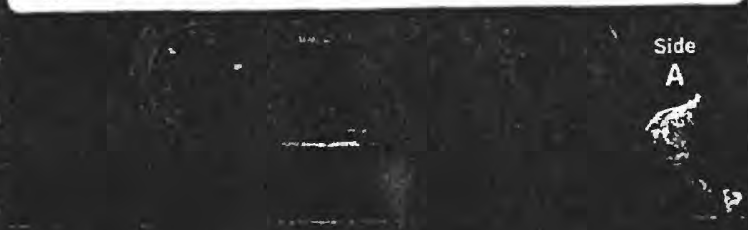

$09219122 \quad 20+256|T R||c| c$ ar $1922158-5.0$ n ST $\operatorname{com} I$ DR2 72 JuQ 8769

$\therefore: 0 \pi 9219222 \infty-5.0$ ITR/LER

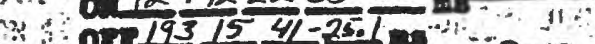

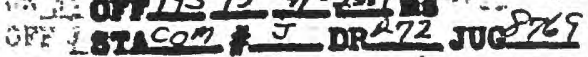




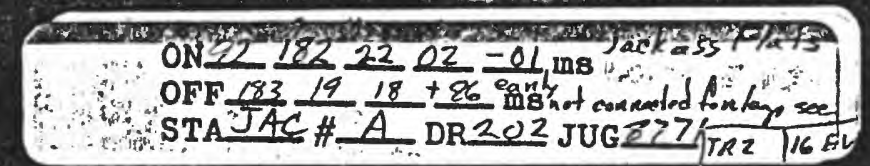

1

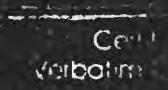

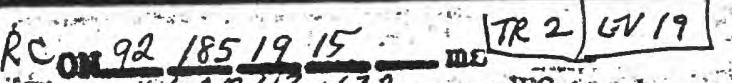

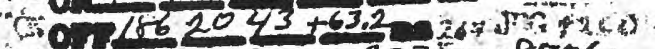

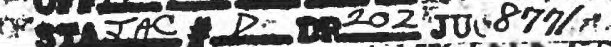

ic

\section{1}

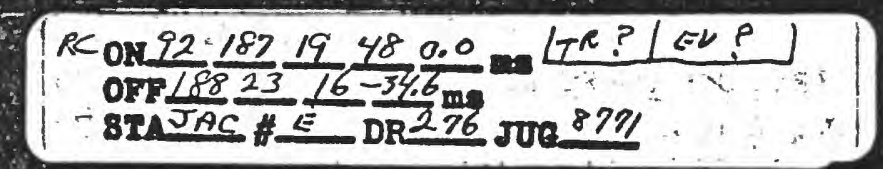

T 300NH

Certified by

Verbatim Corporation

Slde

A
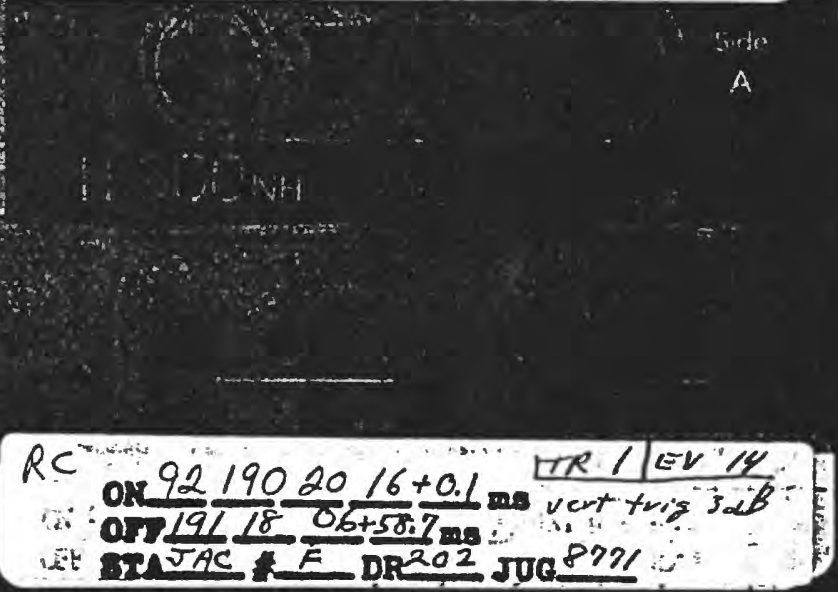

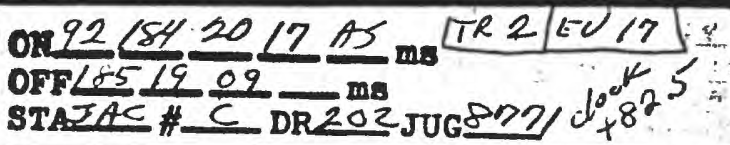

Side

A

T 300NH 


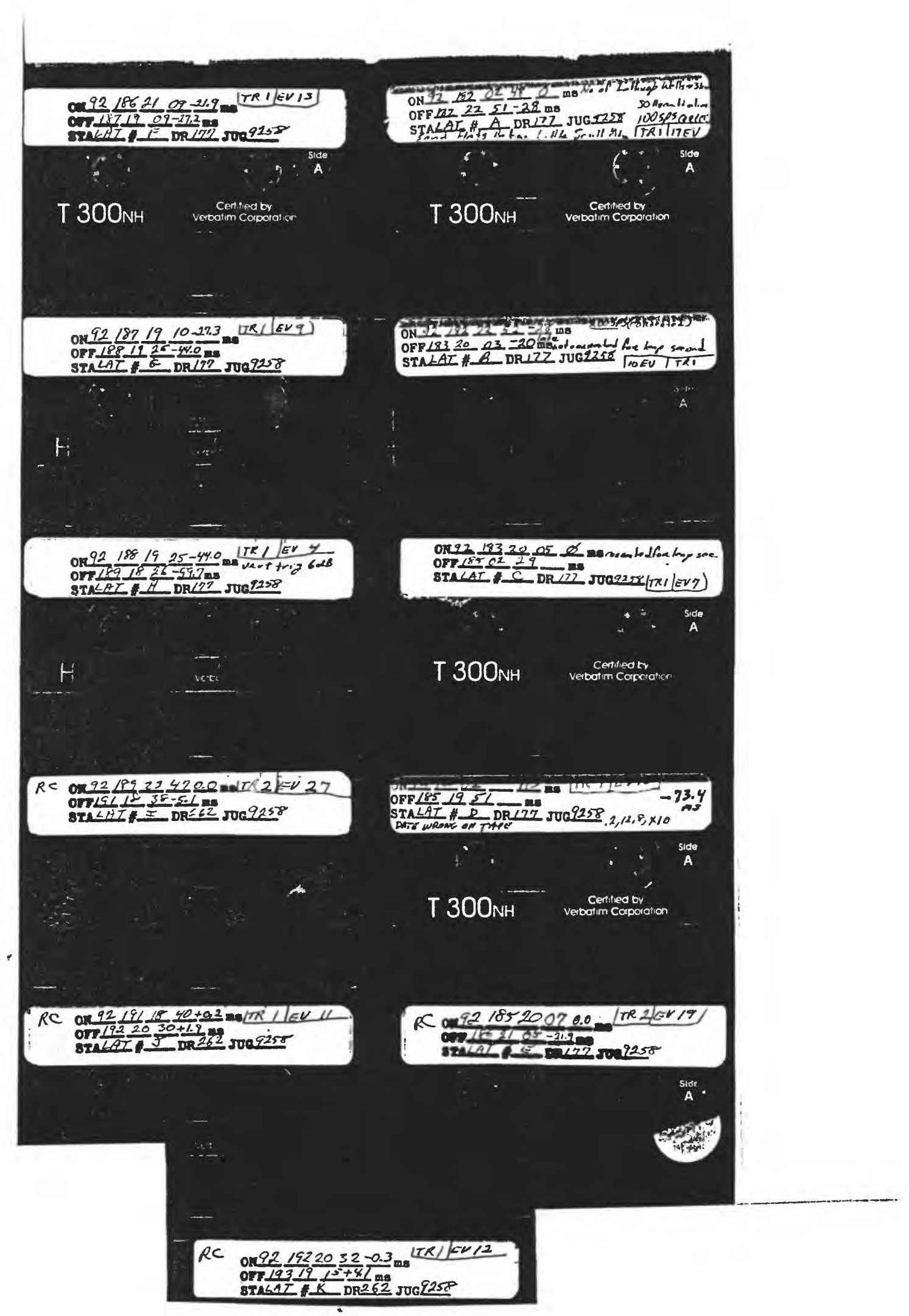

Tape D's label is difficult to read for the "ON" entry: ON $\underline{92} \underline{185} \underline{02}$ - $\underline{\text { AS ms. }}$ 


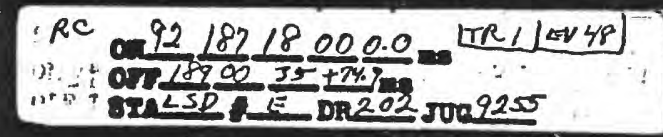

H

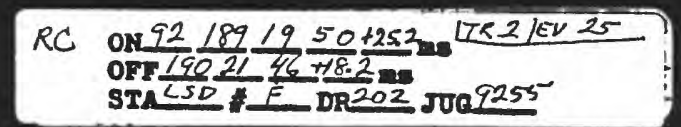

Side

T $300_{N H}$

Cerified by

verbatim Corporation

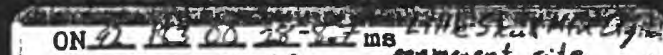

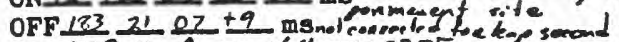
STA $\angle 50 \#$ A DR 164 JUG $\frac{225}{100} \sqrt{61 E V ~ T R 4}$
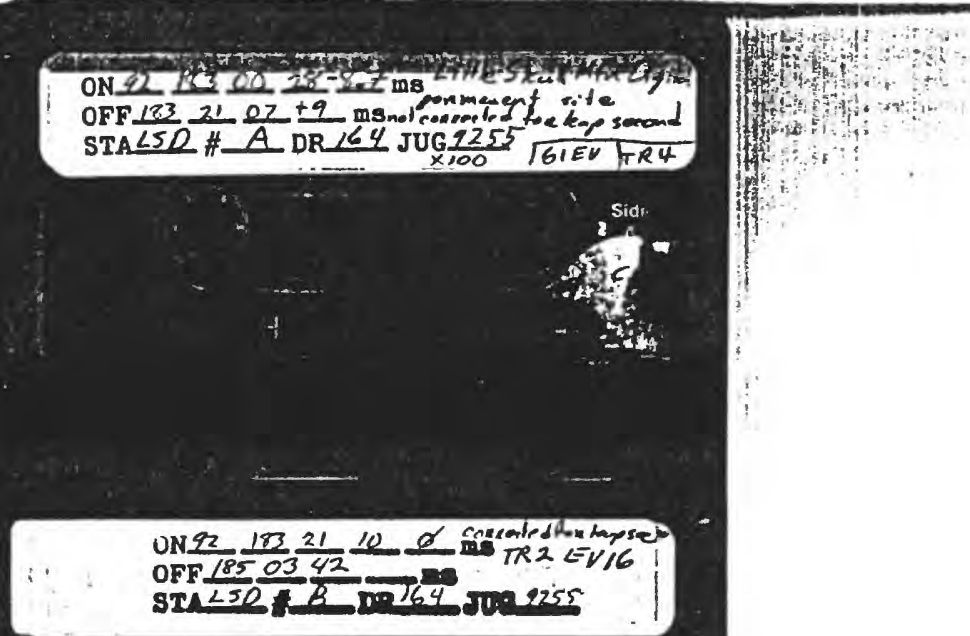

UN92 183 $0 F 51850342$

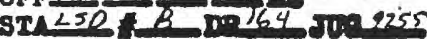

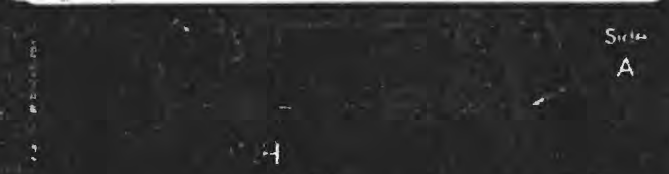

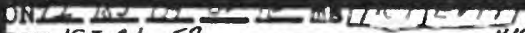

OFF $1852152=149.1 \mathrm{~ms}$

STA $\angle S O \#-D R 164$ JUG9255

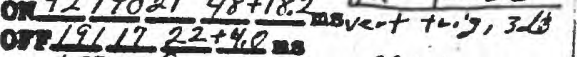
82 $\angle S D E D R \angle 27$ JUC $9255^{\circ}$

$2,12 \cdot 8, \times 10$

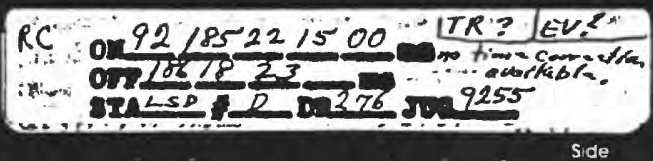
T 300 NH
Certified tov verbalim Corpoterict:

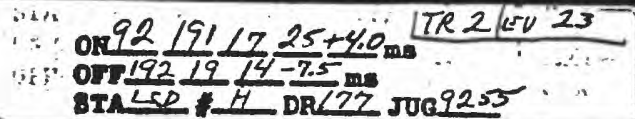

F:

Tapes A, B and C are annotated with the wrong jug (seismometer) serial number of 164. The serial number is 184 . Tape $F$ is annotated with the wrong jug serial number of 177 . It is 202 . See the station summary listing for LSD. 


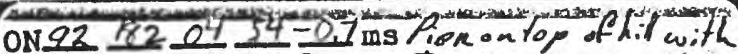
OFF $18221.19-1.2 \mathrm{~ms}$ Tower STA TOWH -4 DR2 64 JUG 4257

TRZ/ICEV

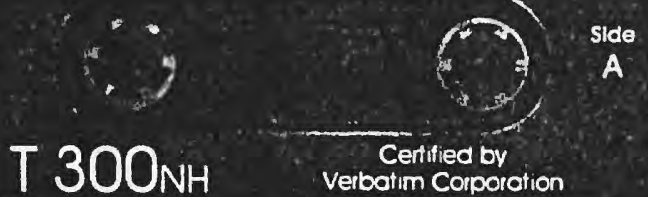

Side

Verbatim Corporation

T 300NH

Centified by

Verbatim Corporation

$0492,182,2120-1.2=$

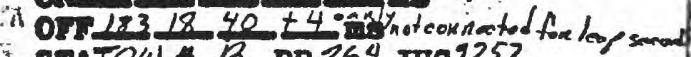
STATOW \# DR264 JUG1257 $\mid \overline{R-2|| 3 E V \mid}$

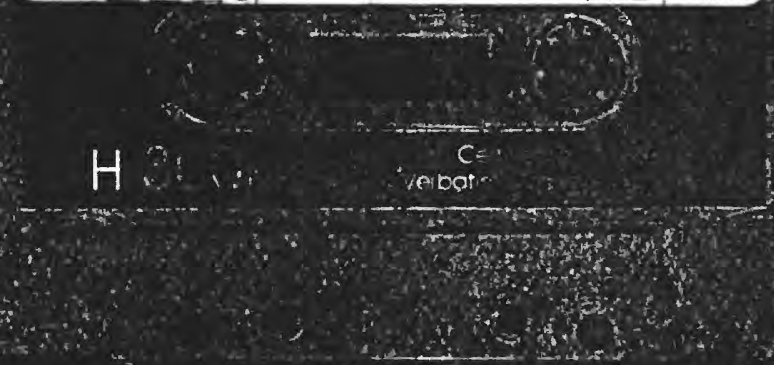

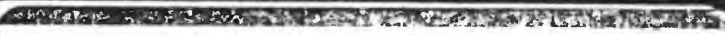

ON $4218318,42+4 \mathrm{~ms}$

OFF 1841853

STA TOW H $C$ DR 264 mII $125: 7 \longdiv { T R - 1 \text { TEV-9 } }$ $\rightarrow$

s. 4.5

$\mathrm{T} 300_{\mathrm{NH}}$

Certified by

Verbatim Corporation

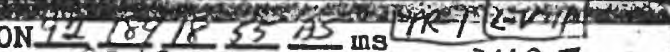

OFF $1857835-349.7$

STATOW \#D DR264 JUG $2252,2,12,8,40$

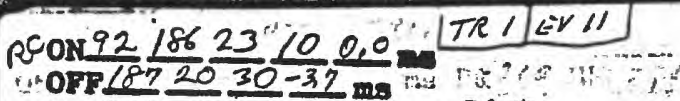

ST TTOW \#E DR264 JUG9257

\section{RC 9218720320.0 ITR/ EE IO 1.188 $1842-11.6=$

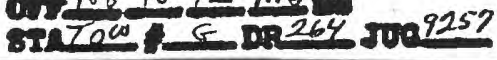

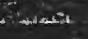

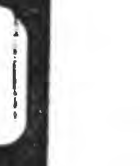

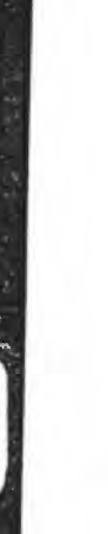

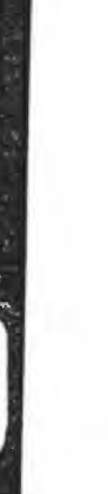

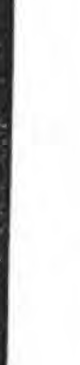




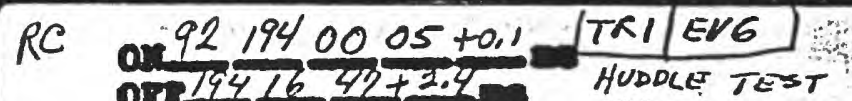 SINARA A DR192 Jue 8772}
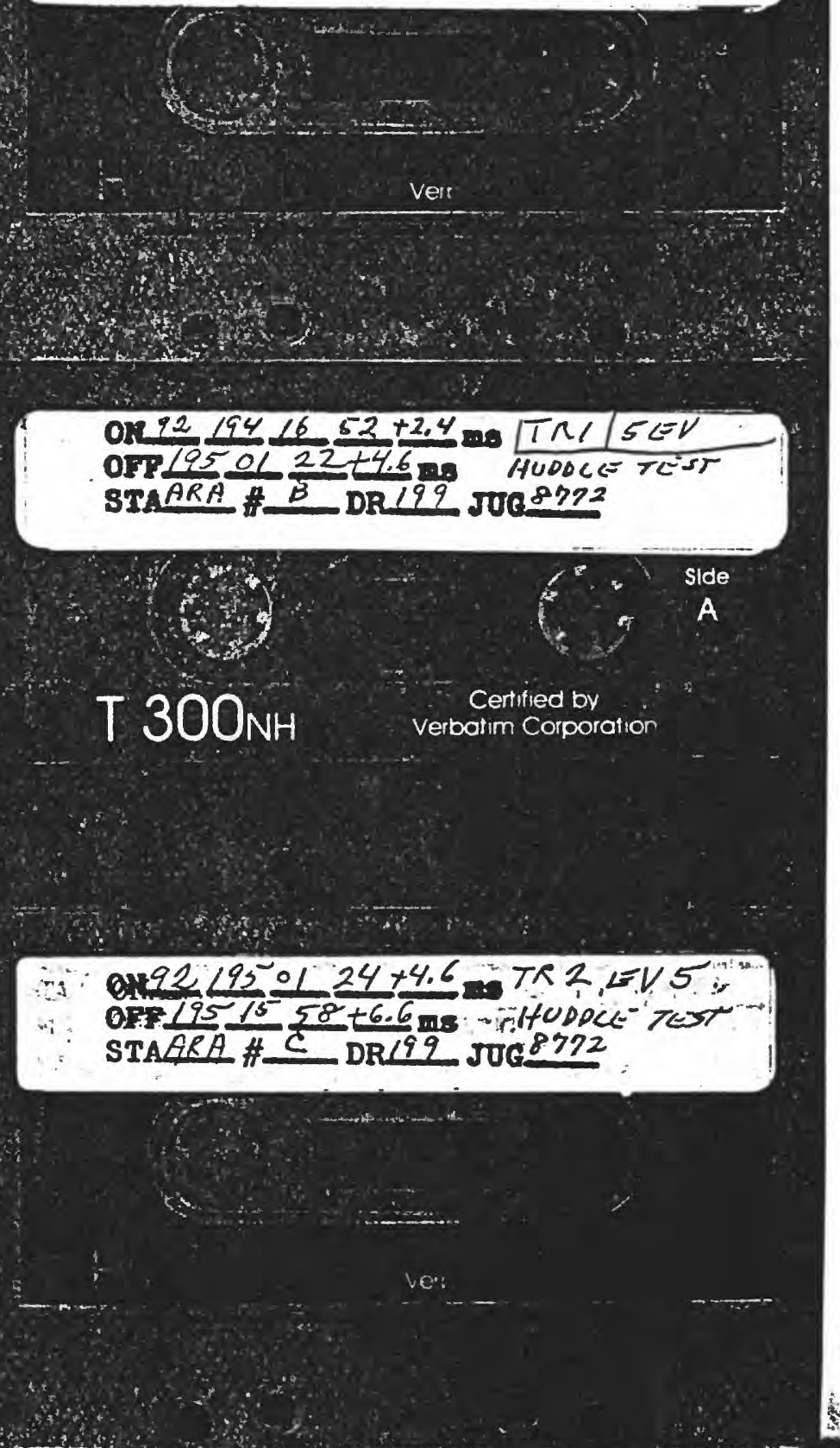


\section{RC oN92 $19400^{\circ 10} 0.0 \mathrm{~m}$ (TRI) EV B

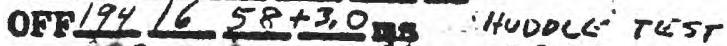 ST, $A R B$ A $A R 261$ JUC 258}

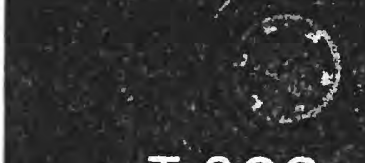

T $300 \mathrm{NH}$

Certified by

Verbatim Corporation

सर

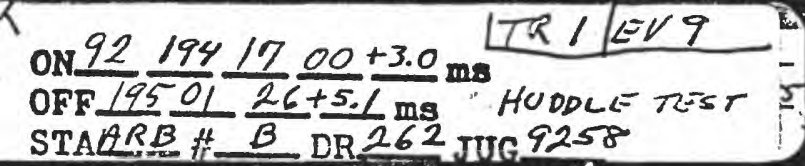

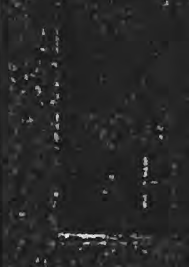

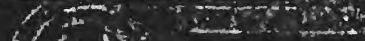
itis $\operatorname{lin}^{2} \sin ^{2}$
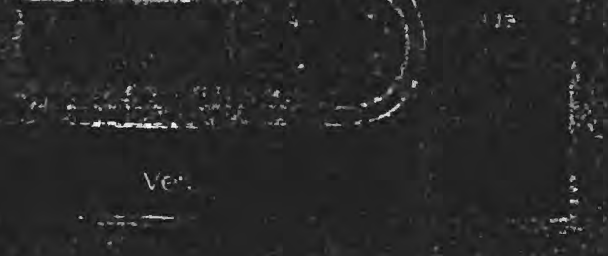

$(80$

148

STAARB \#C. DR262 JUG 1258

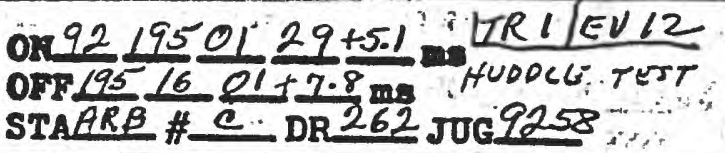

$x^{2+4}+2$

Side

A

T 300 NH 


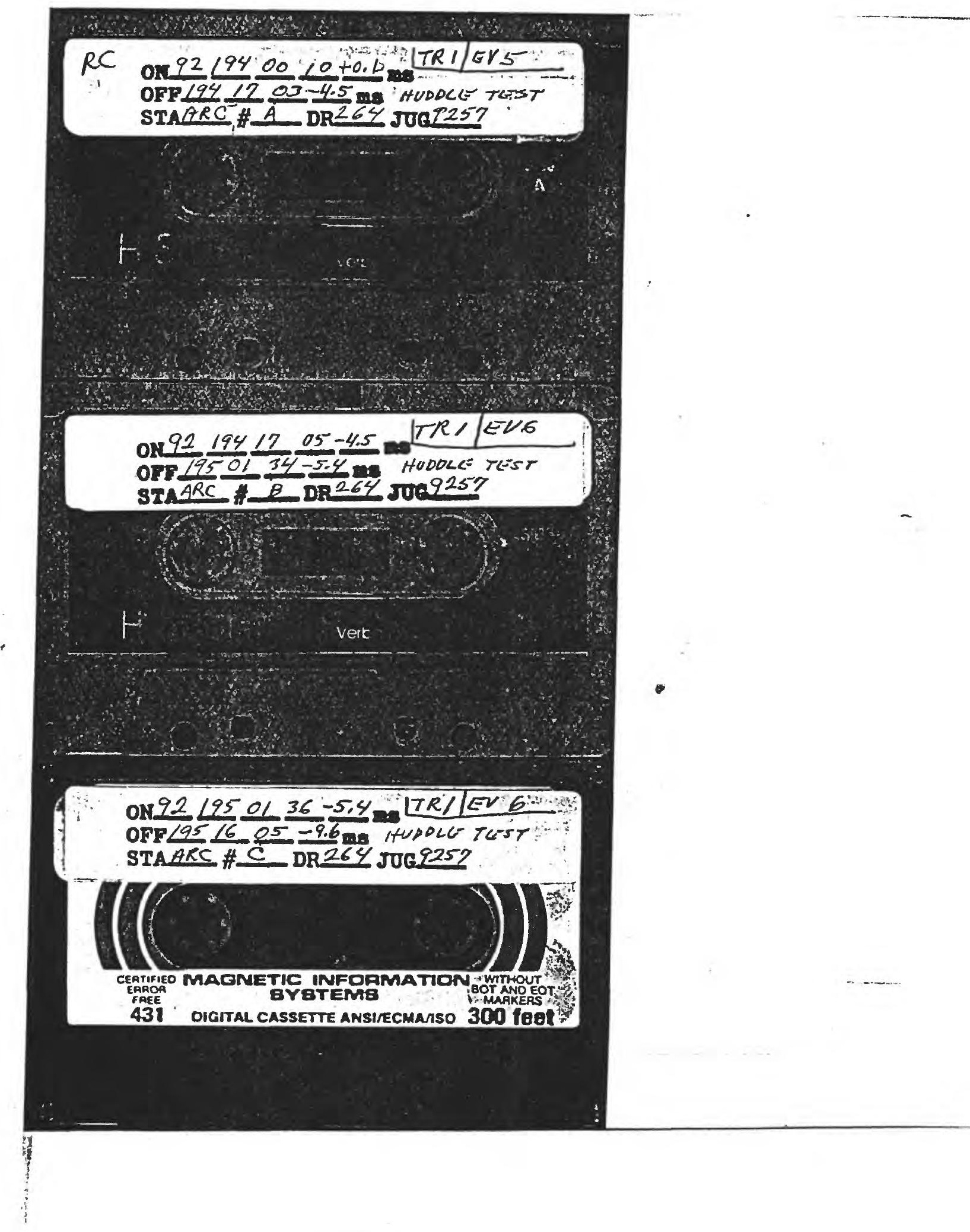




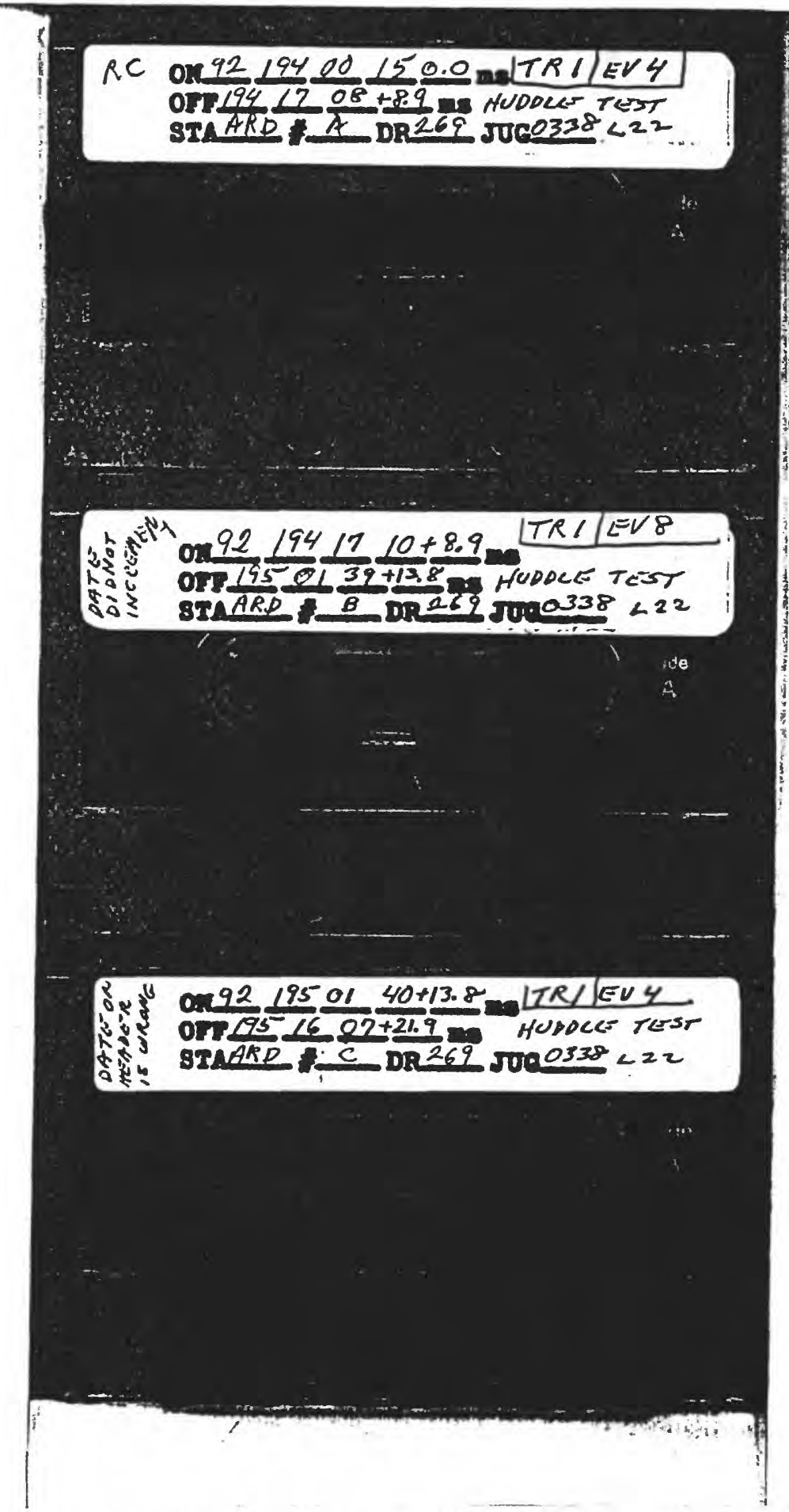

The jug (seismometer) serial number of 338 is wrong. The serial number is 339. See the HUDDLE test station summary listing for station ARD. 


\section{RC ON92 $194000 \angle 200.0=[T R 1] 5 V 4$

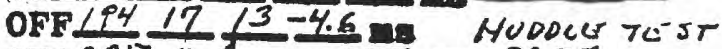 STAQRE \# A DR 177 JOE 9255}
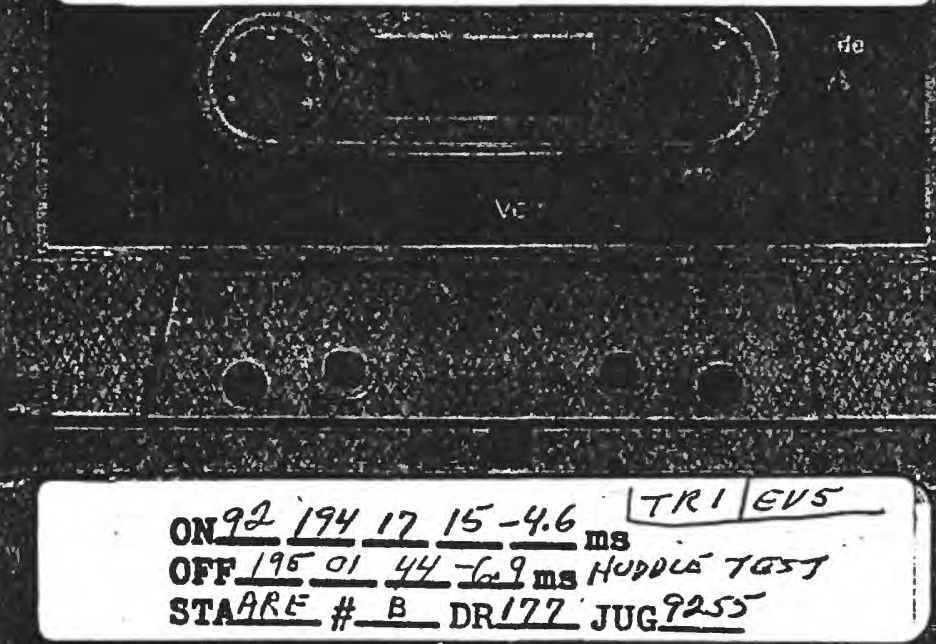

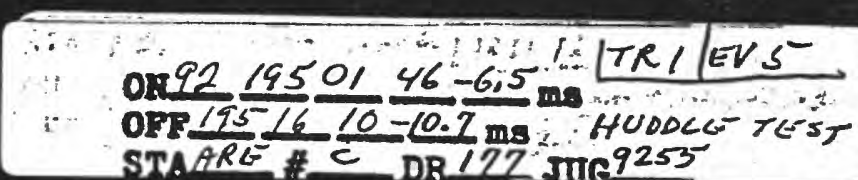


$R C_{\text {ON } 92} 19400550.0 \mathrm{~ms}$ TTR/[E! 4 OFF $1941720-21.0 \mathrm{mis}$ HUOOCL ress. STAARE A $A B 272$ JUG 8769

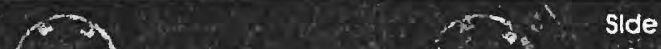

T 300 Certified by

T300NH Verbatim Corporation

$-$

ON $92 \leq 19417 \frac{25}{21.0} \mathrm{~ms}|T R|$ GUC

OFF 195 O1 $49-29.8 \mathrm{~ms}$ HUDOLE TEST STAARF \#B DR272 JUG 8769
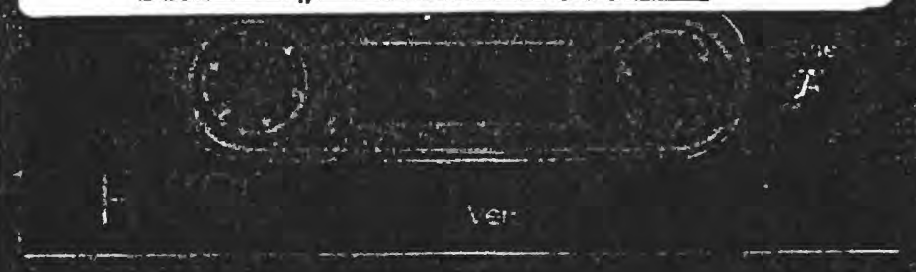

1.

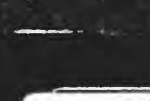

or $921950150-29.8 \mathrm{~ms}$ iTR/GV OFF $1951613-484 \mathrm{~ms}$

STA ARF $A C$ DR 272 JUG 8769

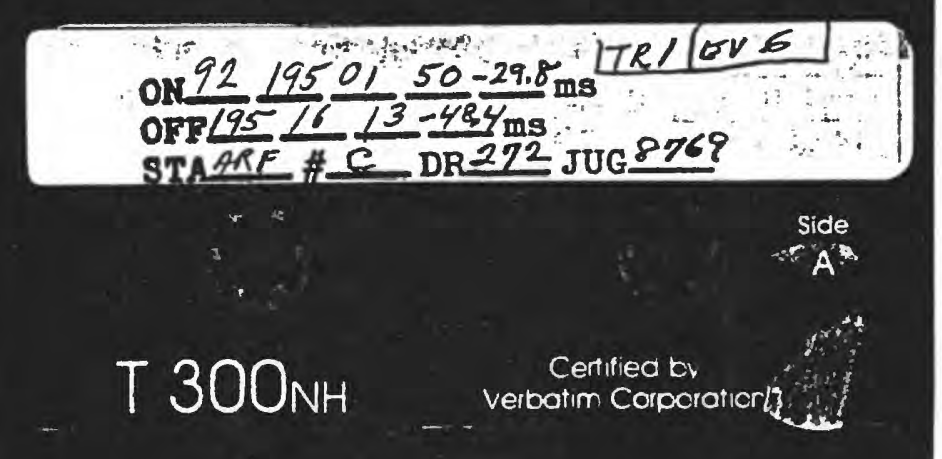




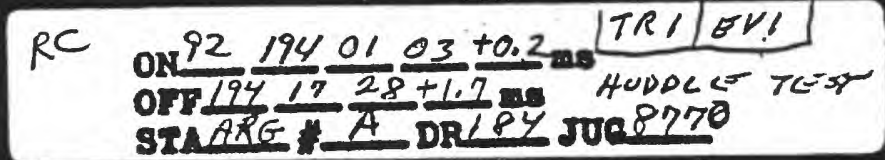
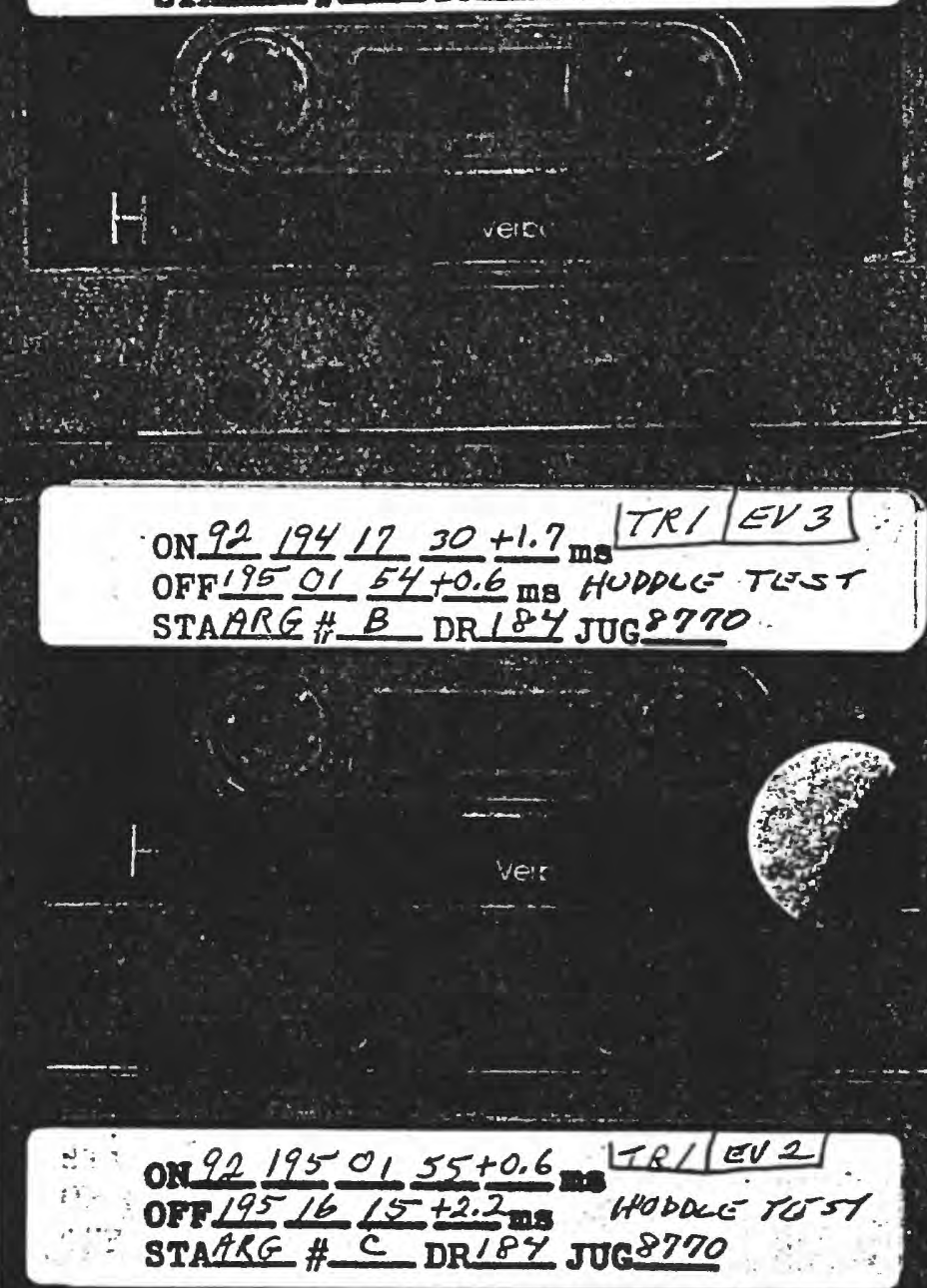

11 


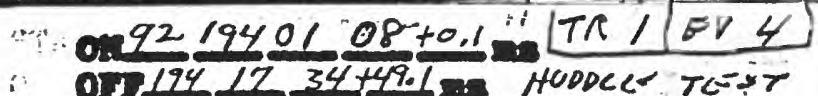

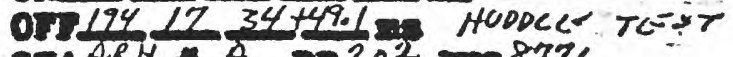 STAARH $A$ DR 202 JU8 877}

$\mathrm{H}$
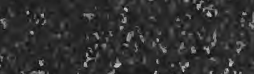

$+2 t^{2}$

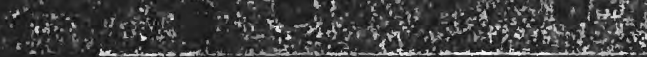

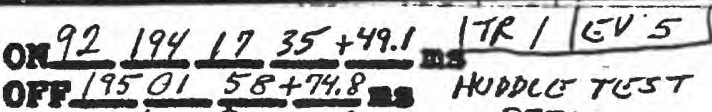
STAARH B DR202 JUG 8771

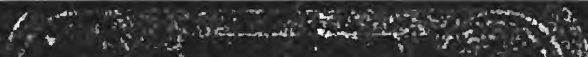

$-$ 


\section{Appendix D}

Photographs of the Station Installations in alphabetical order

NOTE: The photograph of station ARO is also the site of station ARY and the site of the HUDDLE test. 


\section{Station: AR0}

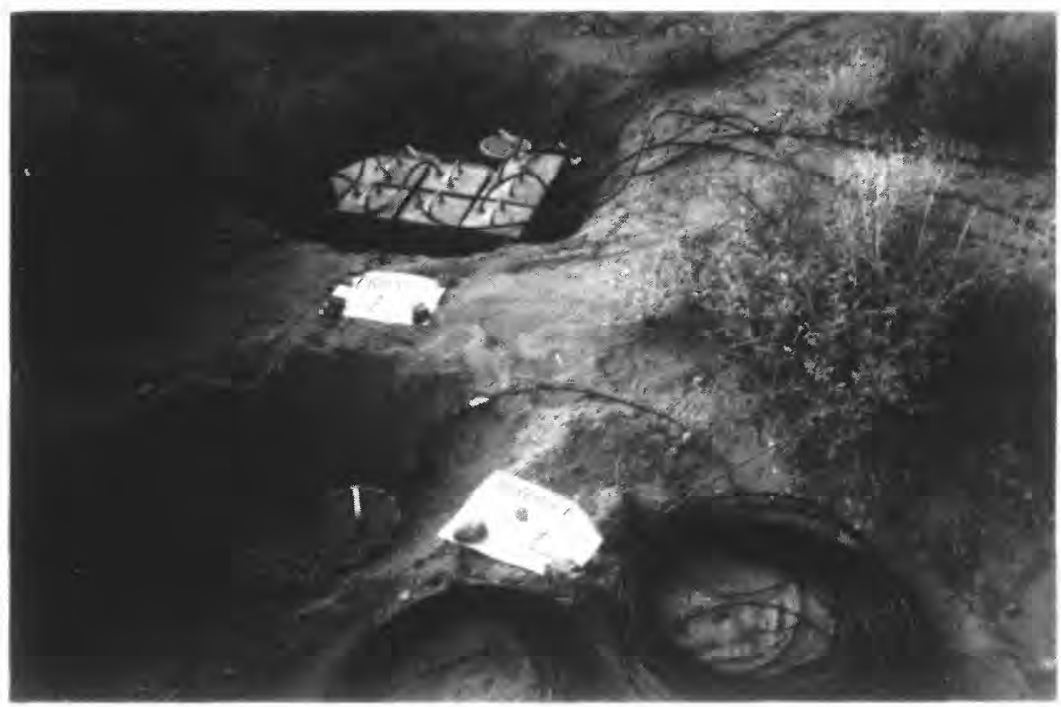

Instrumentation at site. This is also the site of MEQ800 station ARY and of the HUDDLE test.

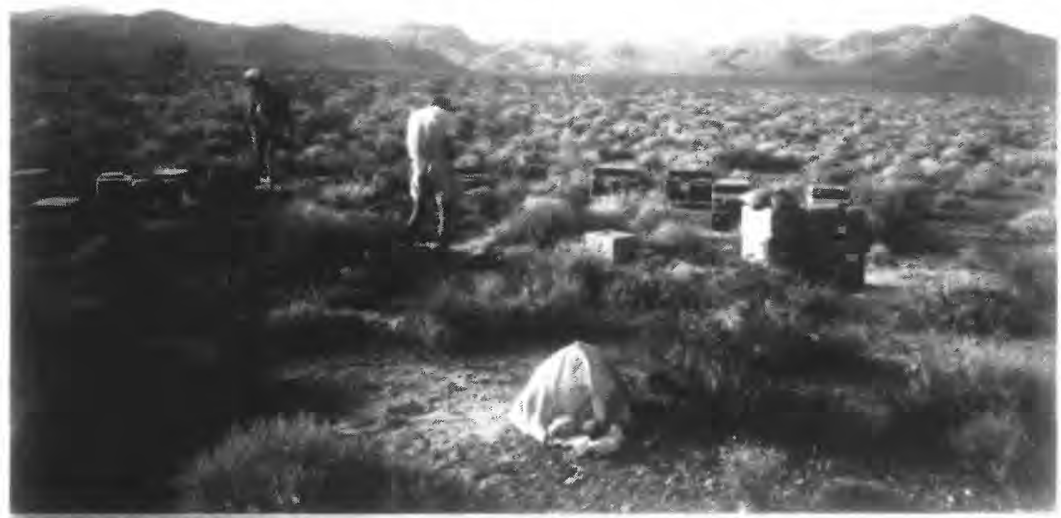

View to the east-northeast across northern Jackass Flats to Lookout Peak (background; center). Note the lone Joshua tree mentioned in the site directions and, behind it, the southward sloping ridge of Kiwi Mwesa.

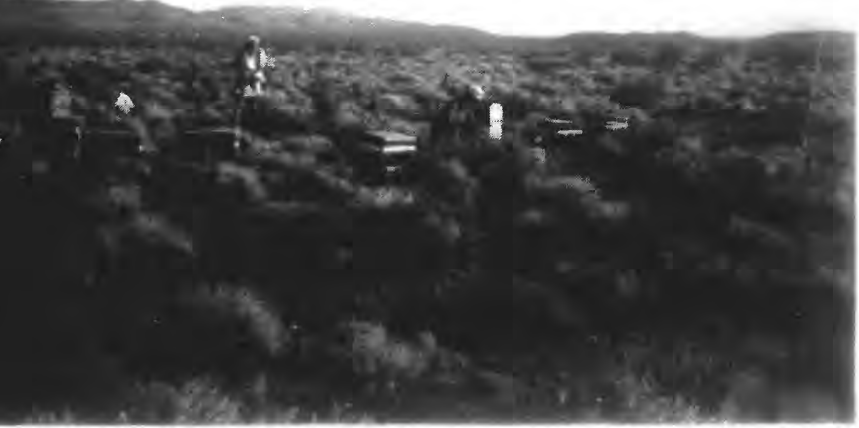

View to the south across Jackass Flats to Little Skull Mountain. 
Station: CAL

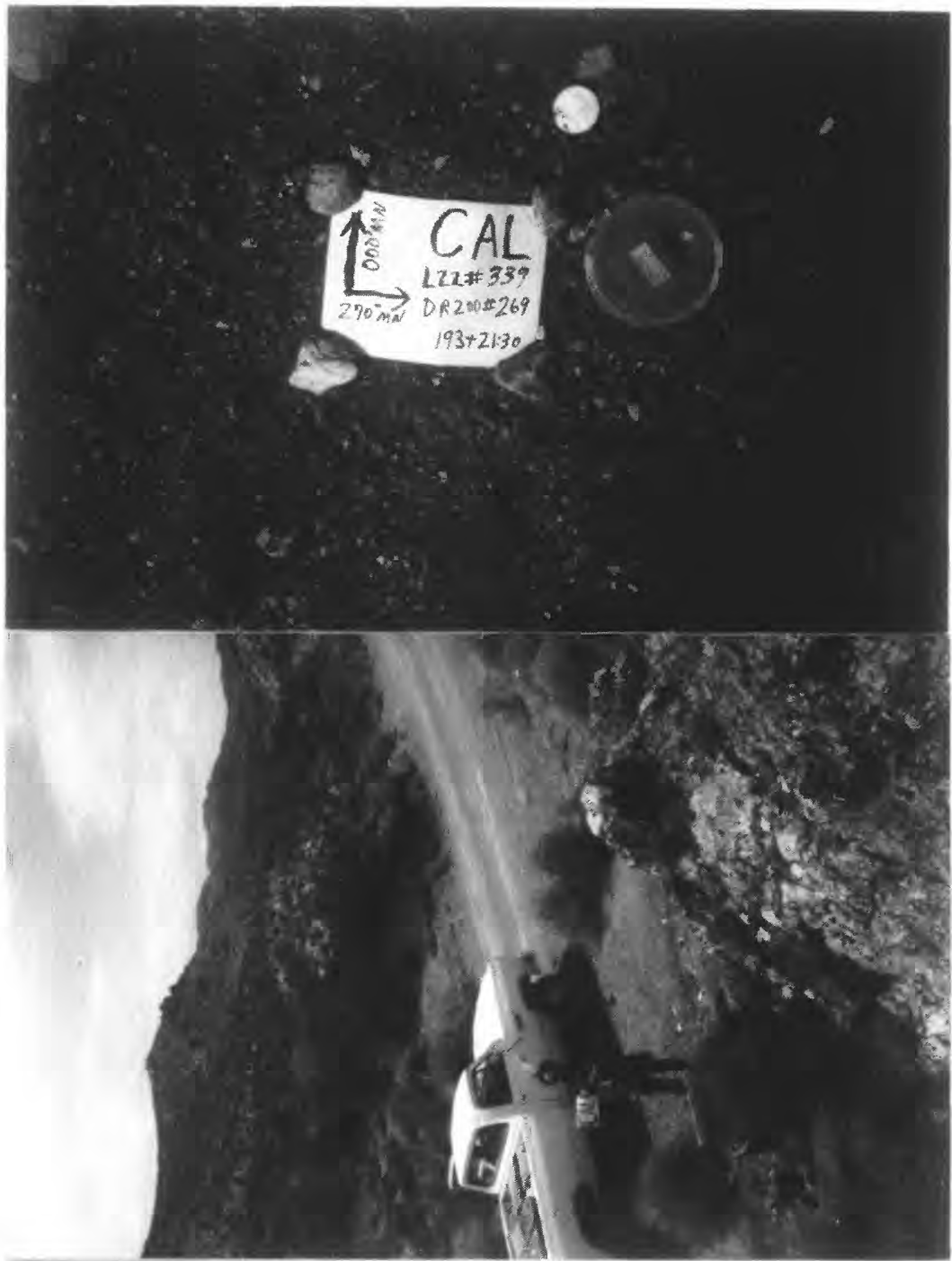

Instrumentation at site.

View to the north-northwest overlooking the rhyolite outcrop described in th site directions/geology.

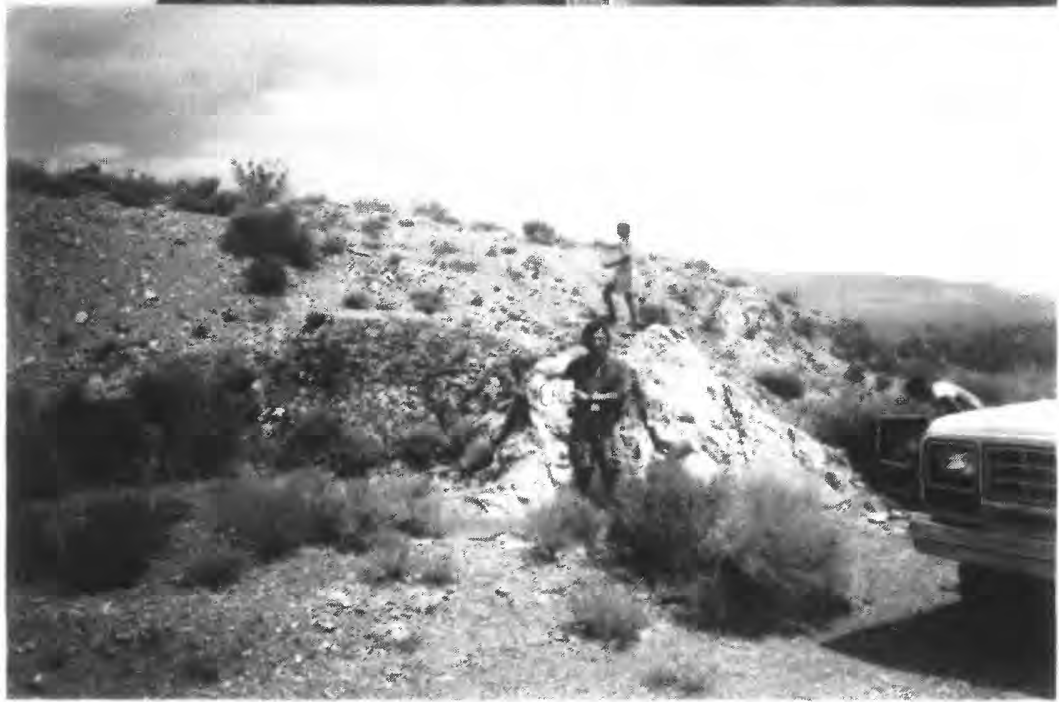

View to the south-southeast overlooking the rhyolite outcrop. Skull Mtn. is in the far background on the right. 
Station: CLO

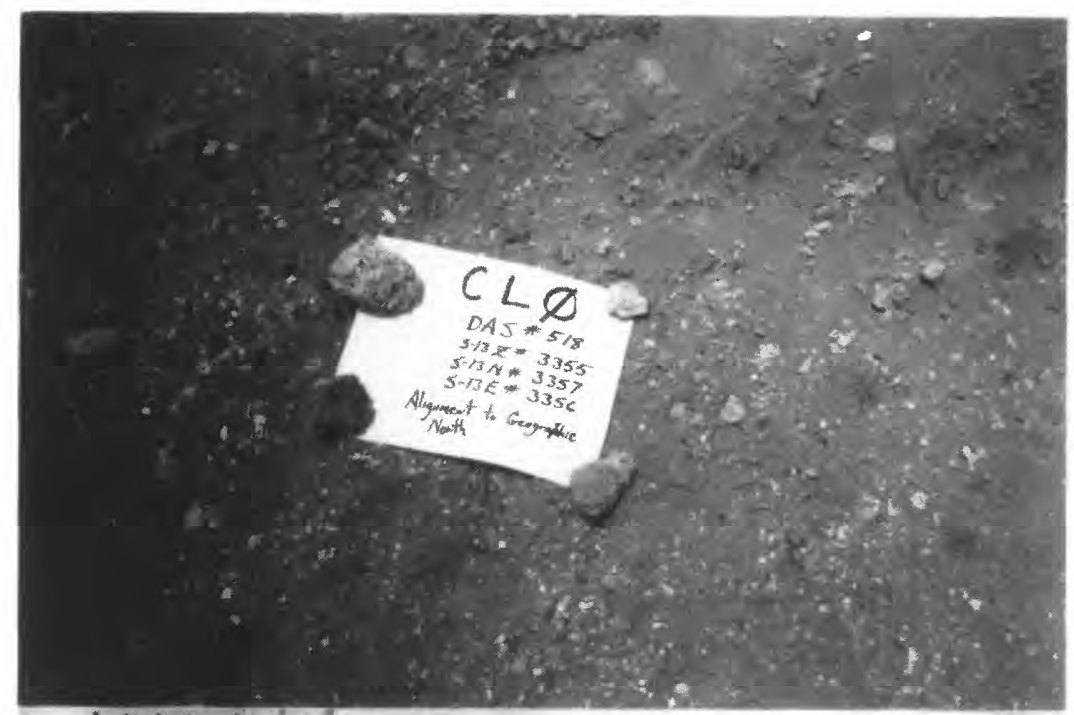

Instrumentation at site. This site is being prepared for a permanent digital installation.

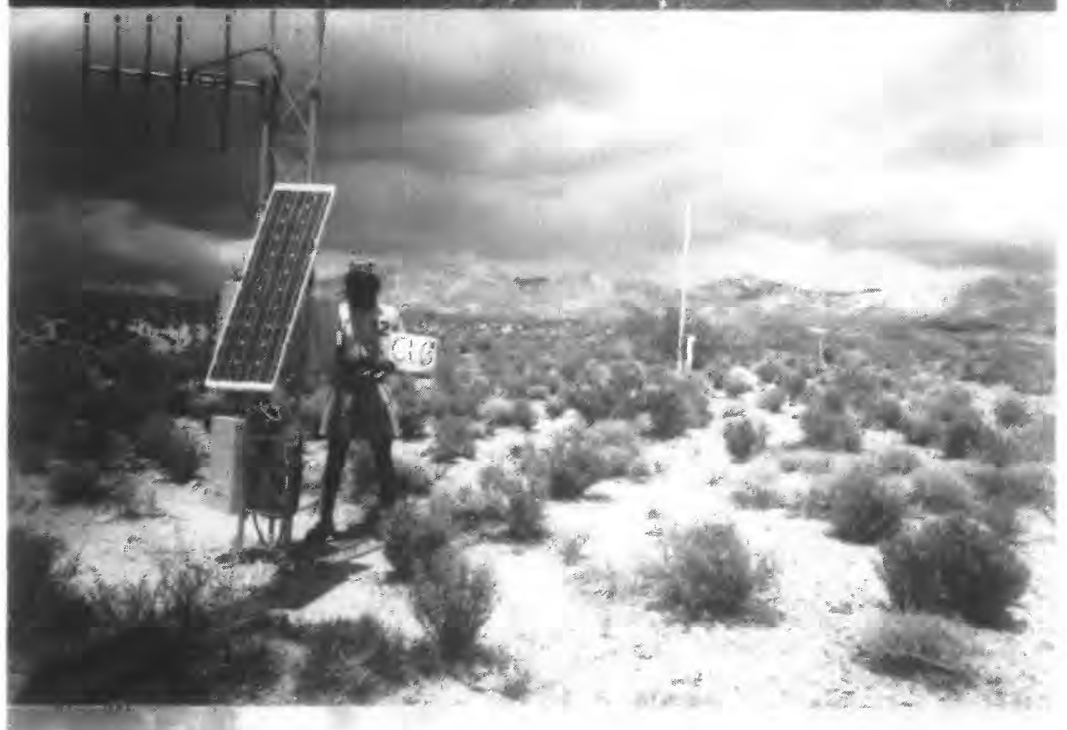

View to the north along crest of hill mentioned in the site directions towards Calico Hills.

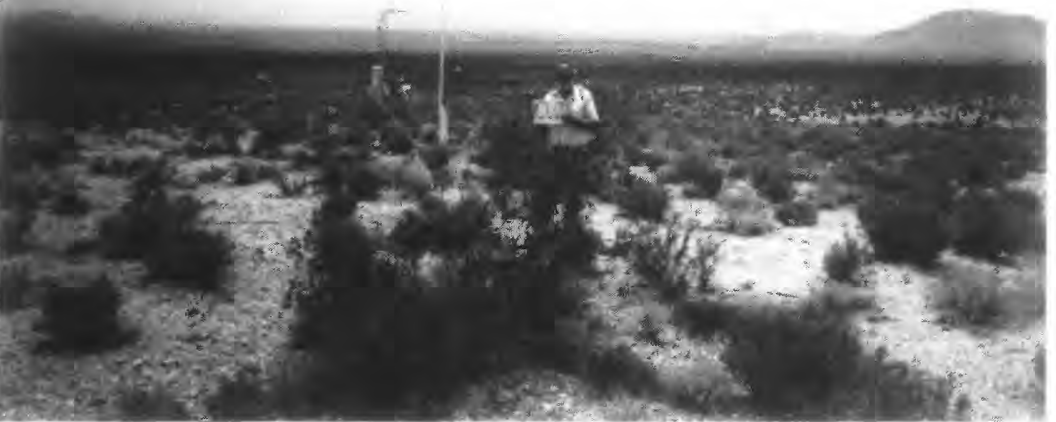

View to the south overlooking Jackass Flats with Busted Butte on the right. 


\section{Station: COM}
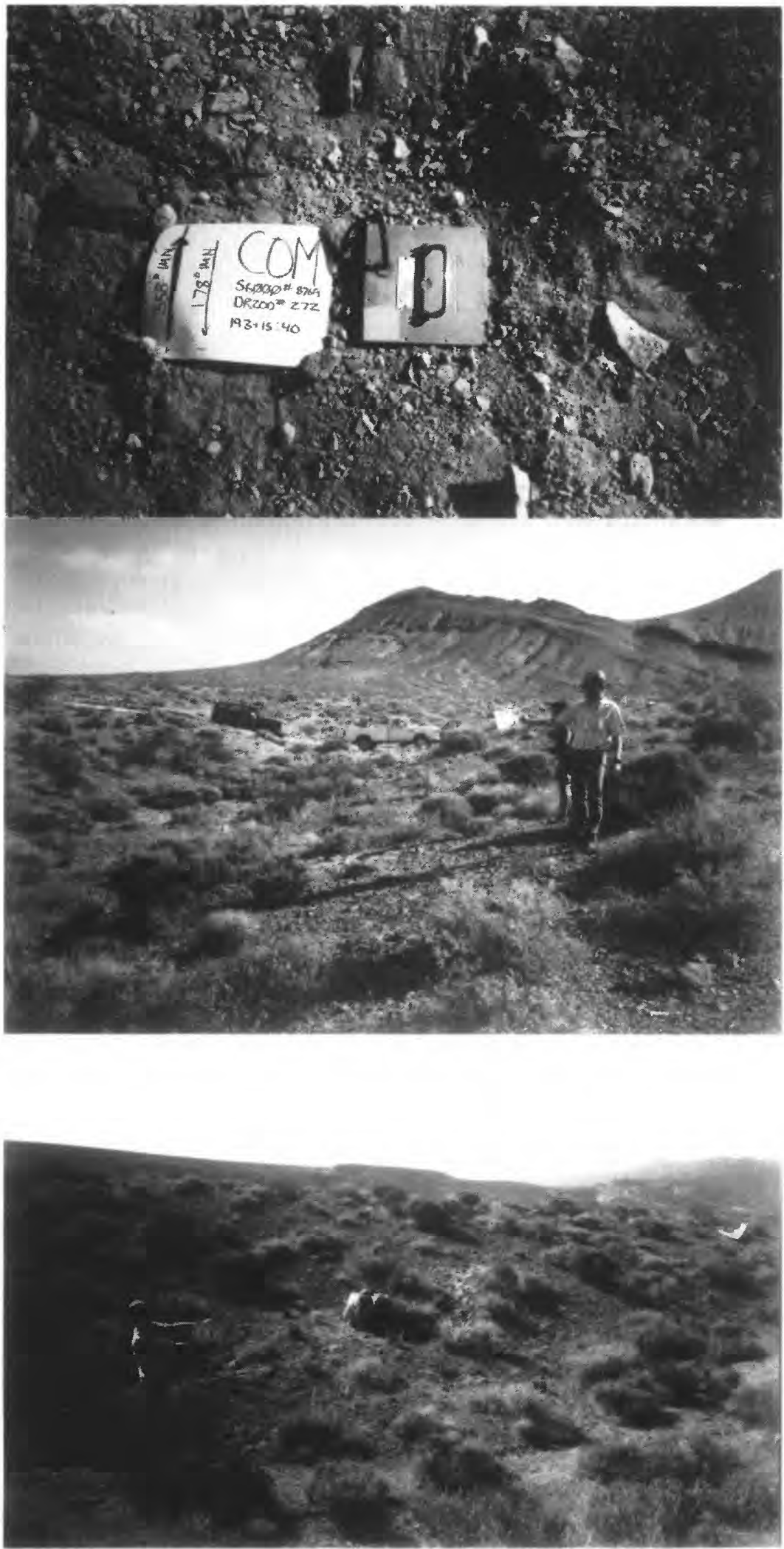

Instrumentation at site.

View to the north of the southern tip of Skull Mtn. The vehicles are parked at bottom of the third dip described in the site directions.

View to the south-southeast overlooking Rock Valley. Specter Range is in the background on the upper right. 


\section{Station: $\mathbf{H} 50$}

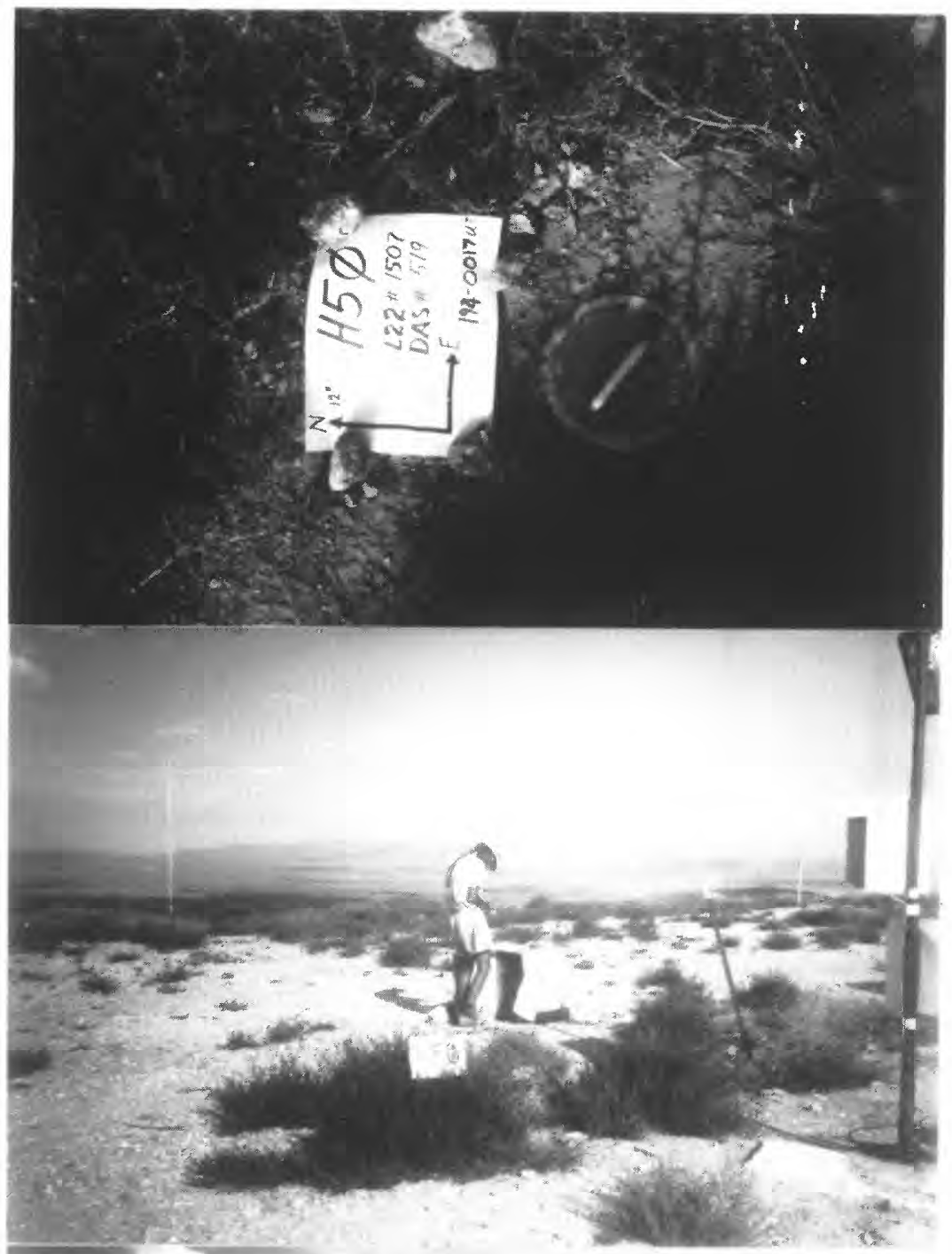

Instrumentation at site. We colocated our instruments with Water Resources' H5 well on top of Yucca Mtn. The site is on the north side of Yucca Mtn. ridge.

View to the east-southeast across Jackass Flats to Skull Mtn. (background; right of the antenna).

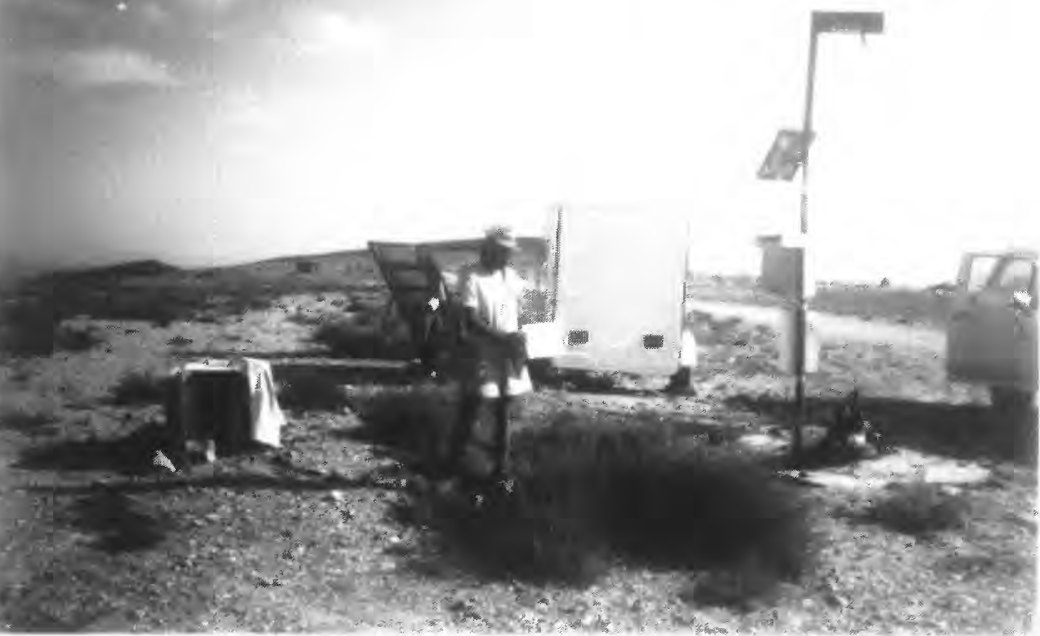

View to the south along the ridge of Yucca Mtn. The water well is just right of the person and the seismometer is located in between. 
Station: JAC

(not TAC)
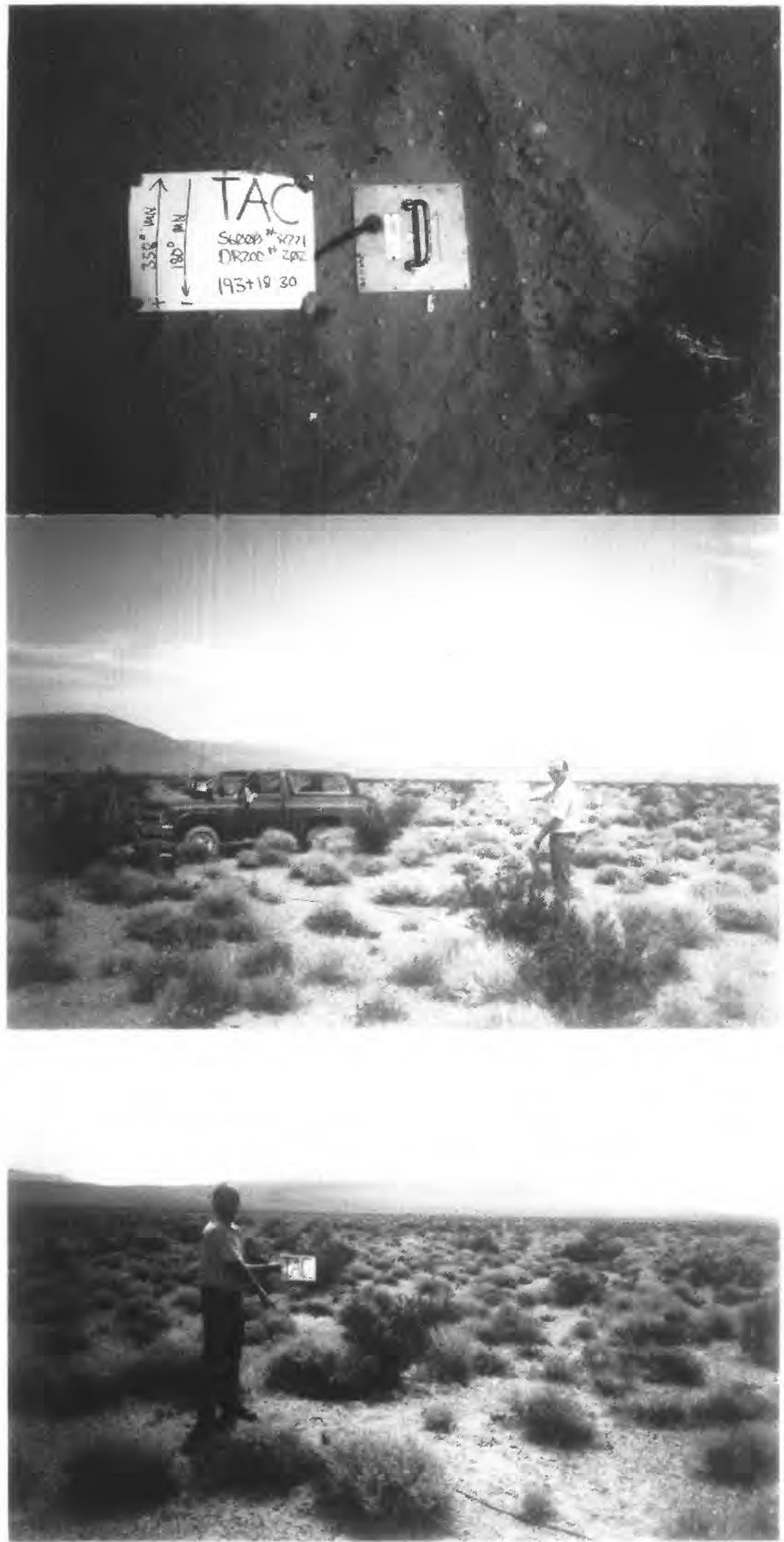

Instrumentation at site.

View to the west-northwest with Busted Butte on the left beyond the telephone lines mentioned in the site directions. The low flat ridge in the background is the ridge of Yucca Mountain.

View to the east-southeast across Amargosa Desert to Little Skull Mtn. prominently sloping northward in the background. 
Station: LAT

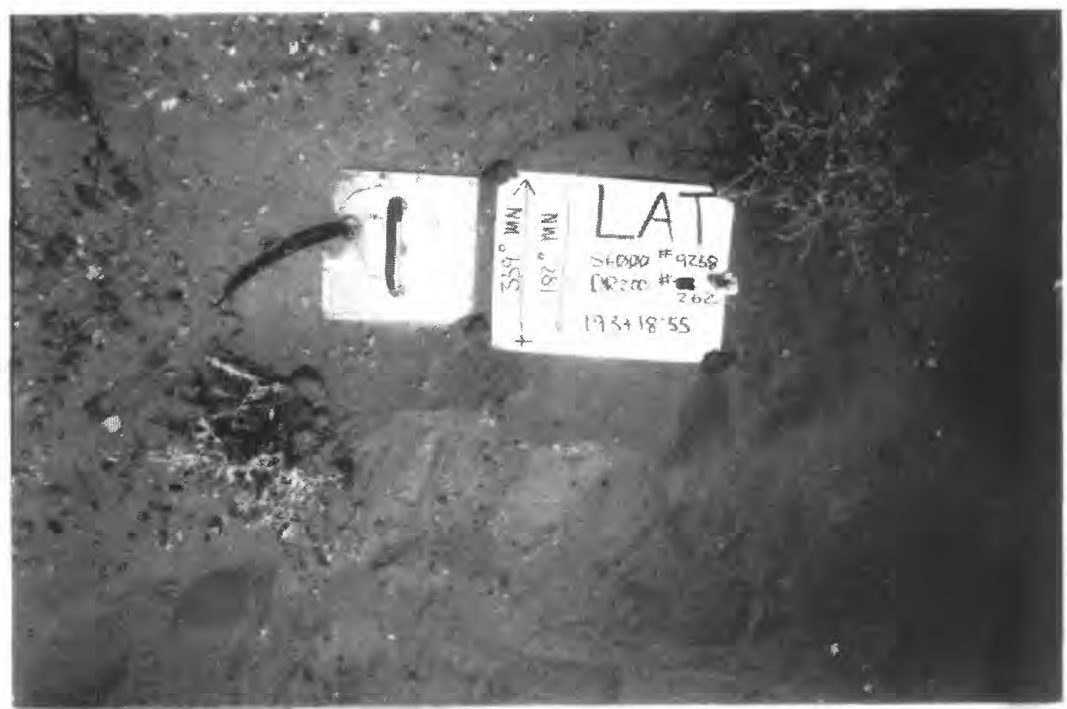

Instrumentation at site.

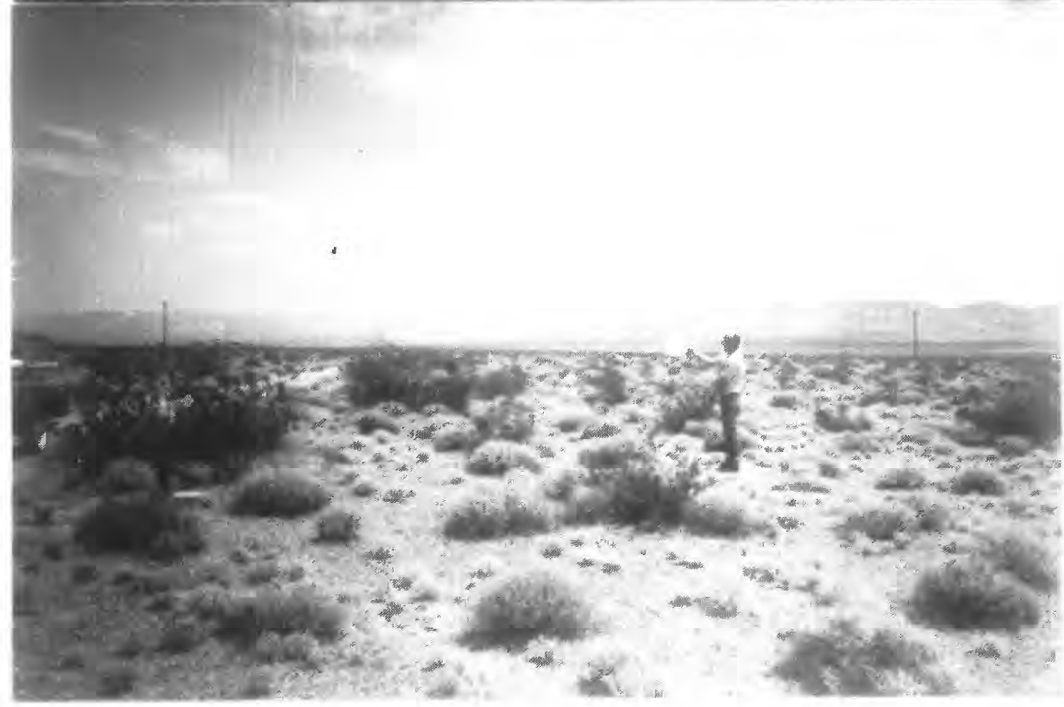

View to the north-northeast across northeastern Amargosa Desert with Little Skull Mtn. in the background behind the person. Note the USGS benchmark (foreground; left) mentioned in the site directions.

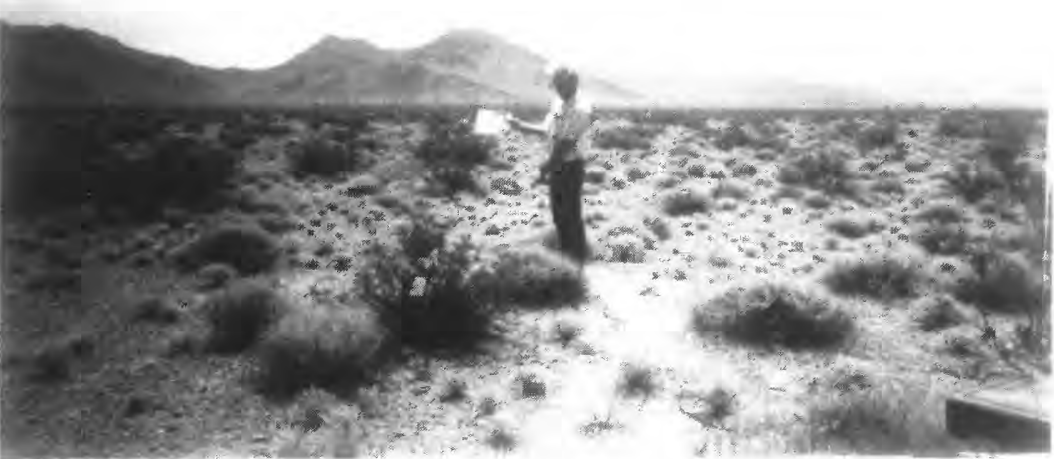

View to the east-southeast across eastern Amargosa Desert with Striped Hills in the background just left of the person. 


\section{Station: LSD}

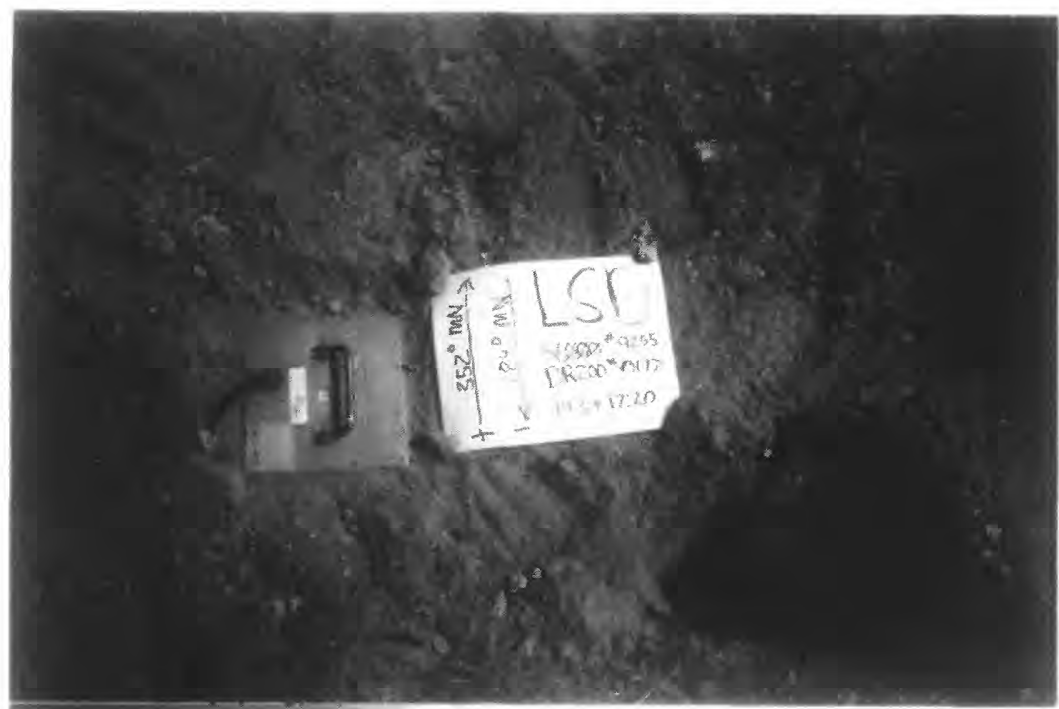

Instrumentation at site. The station is located on top of Little Skull Mountain.

This site is being prepared for a permanent digital installation.

View to the north-northeast across Jackass Flats with Lookout Peak (background; center) beyond the tower.

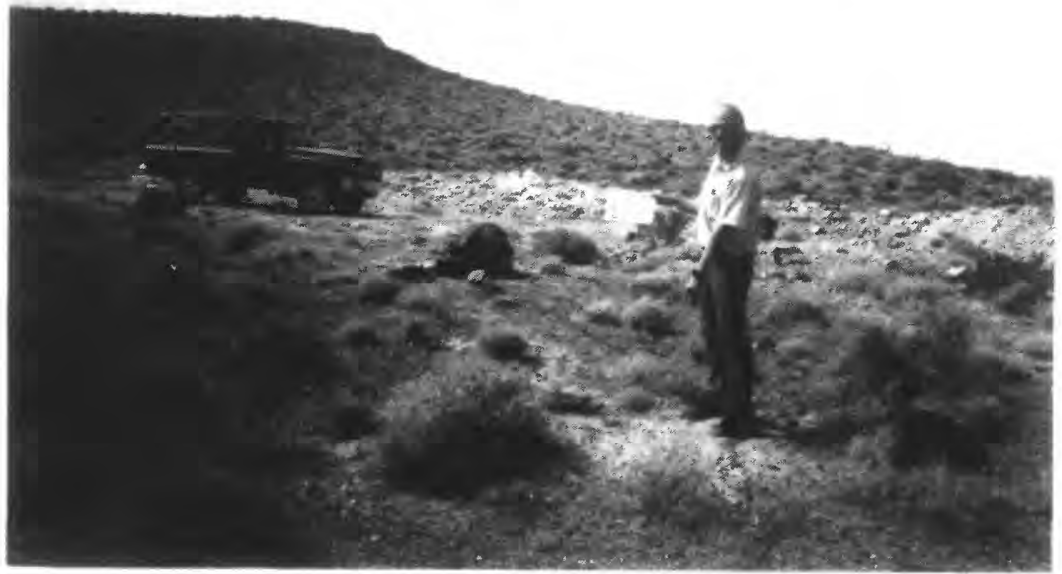

View to the south across the flat area mentioned in the site directions. 

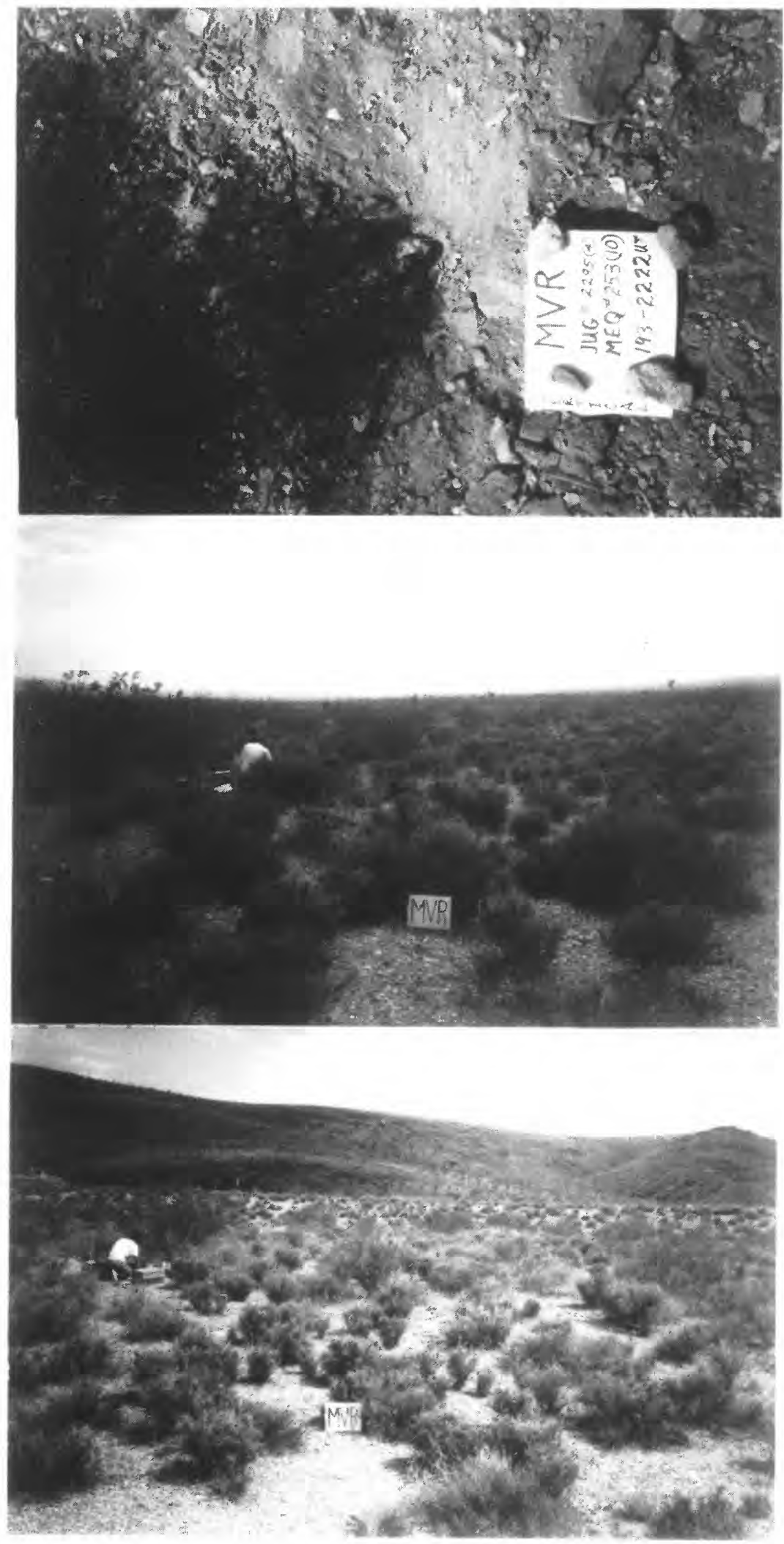

Instrumentation at site.

View to the southwest across Jackass Flats with the domed structures of Test Cell C faintly visible in the middle on the horizon.

View to the east-southeast of the embankment (just below vehicle) mentioned in the site directions and of the northwestern slopes of Kiwi Mesa. 


\section{Station: SLS}
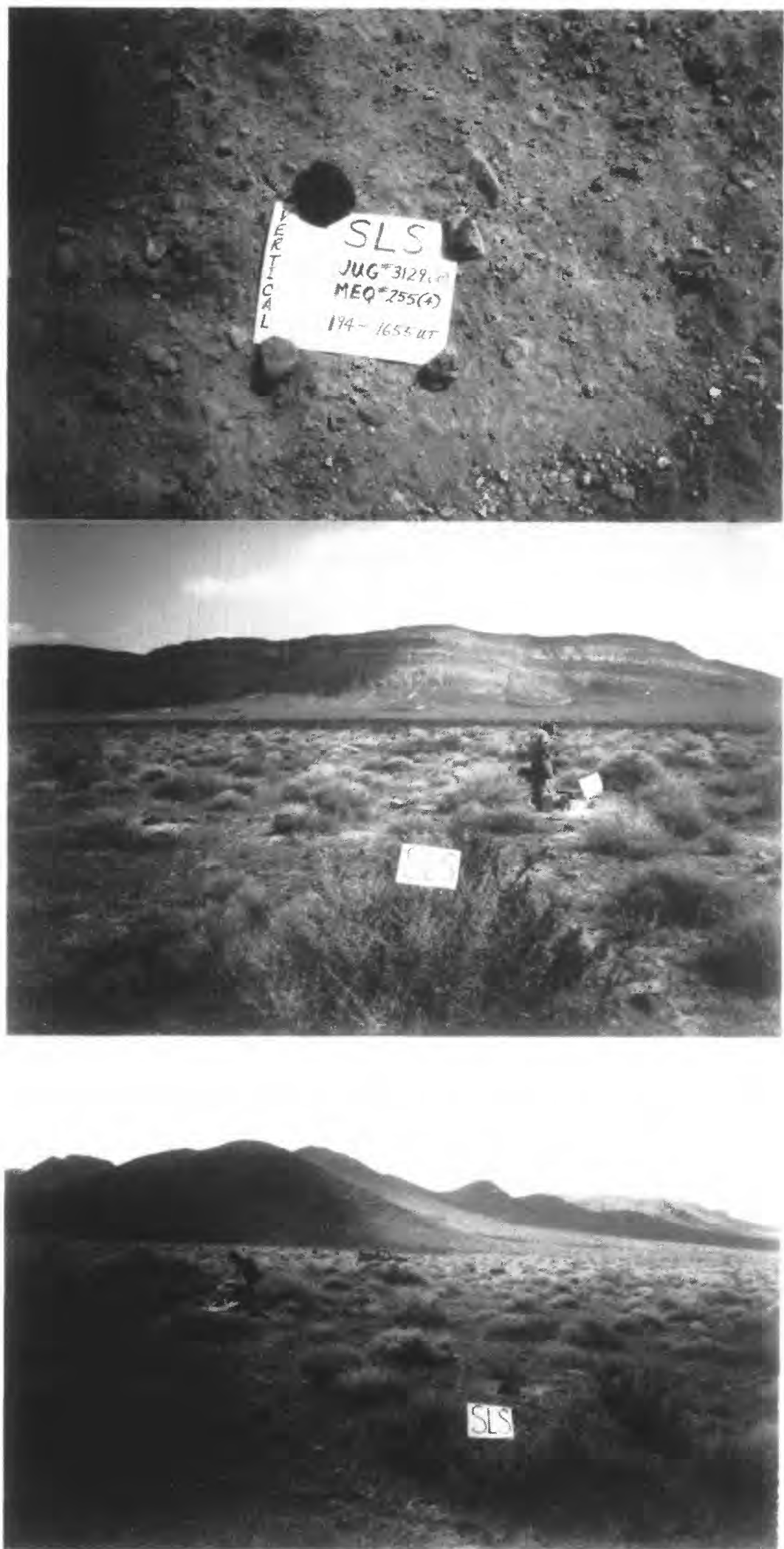

Instrumentation at site.

View to the north of the south flank of Little Skull Mountain.

View to the south-southwest along the western edge of the Specter Range. Rock Valley is on the east side of the hills in the photograph. 


\section{Station: SPE}

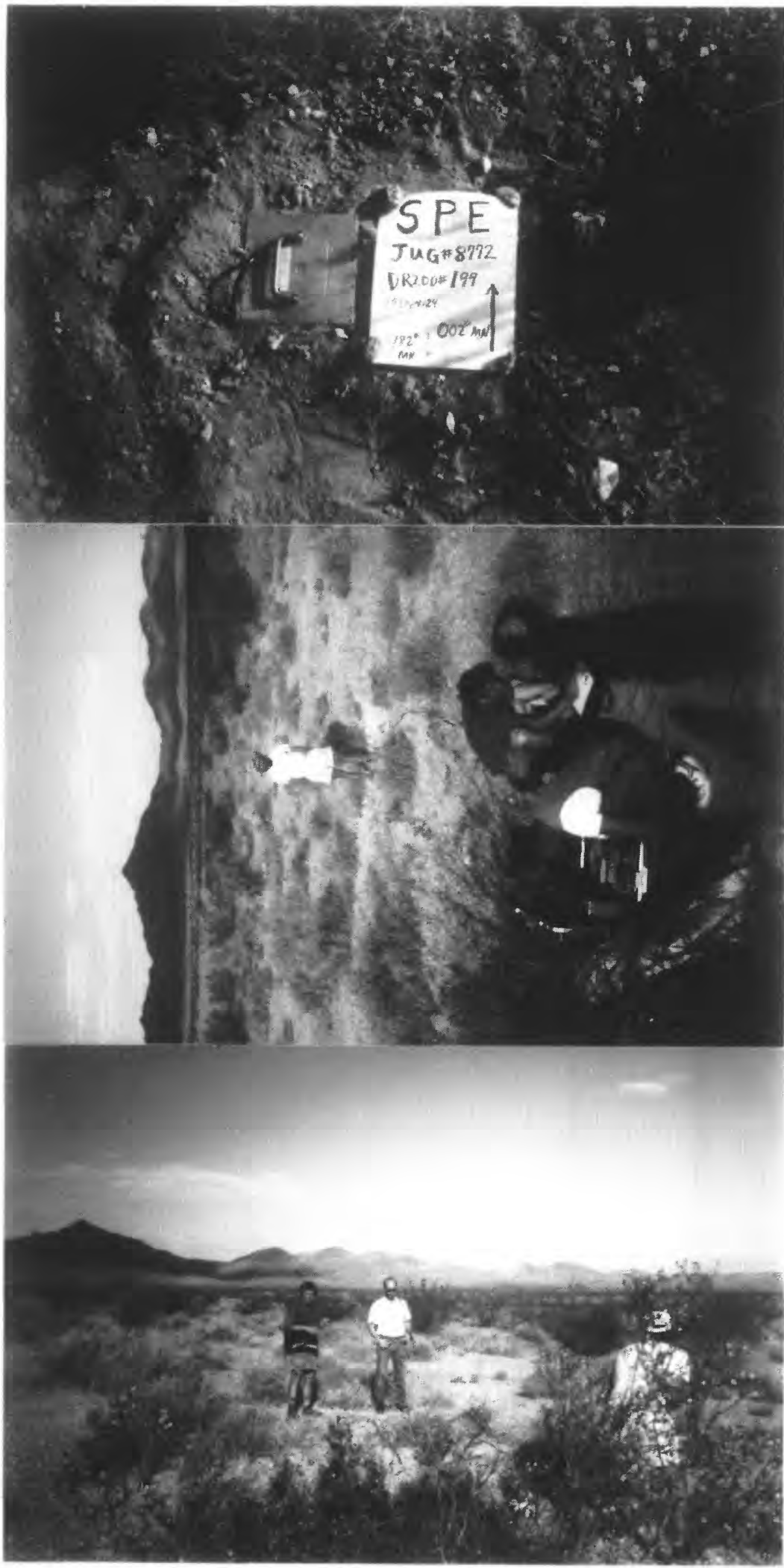

Instrumentation at site.

View to the west overlooking western edge of Mercury Valley towards Specter Mountain (tallest peak) in the Specter Range.

View similar to the photograph above but a little more angled north. 
Station: SPW
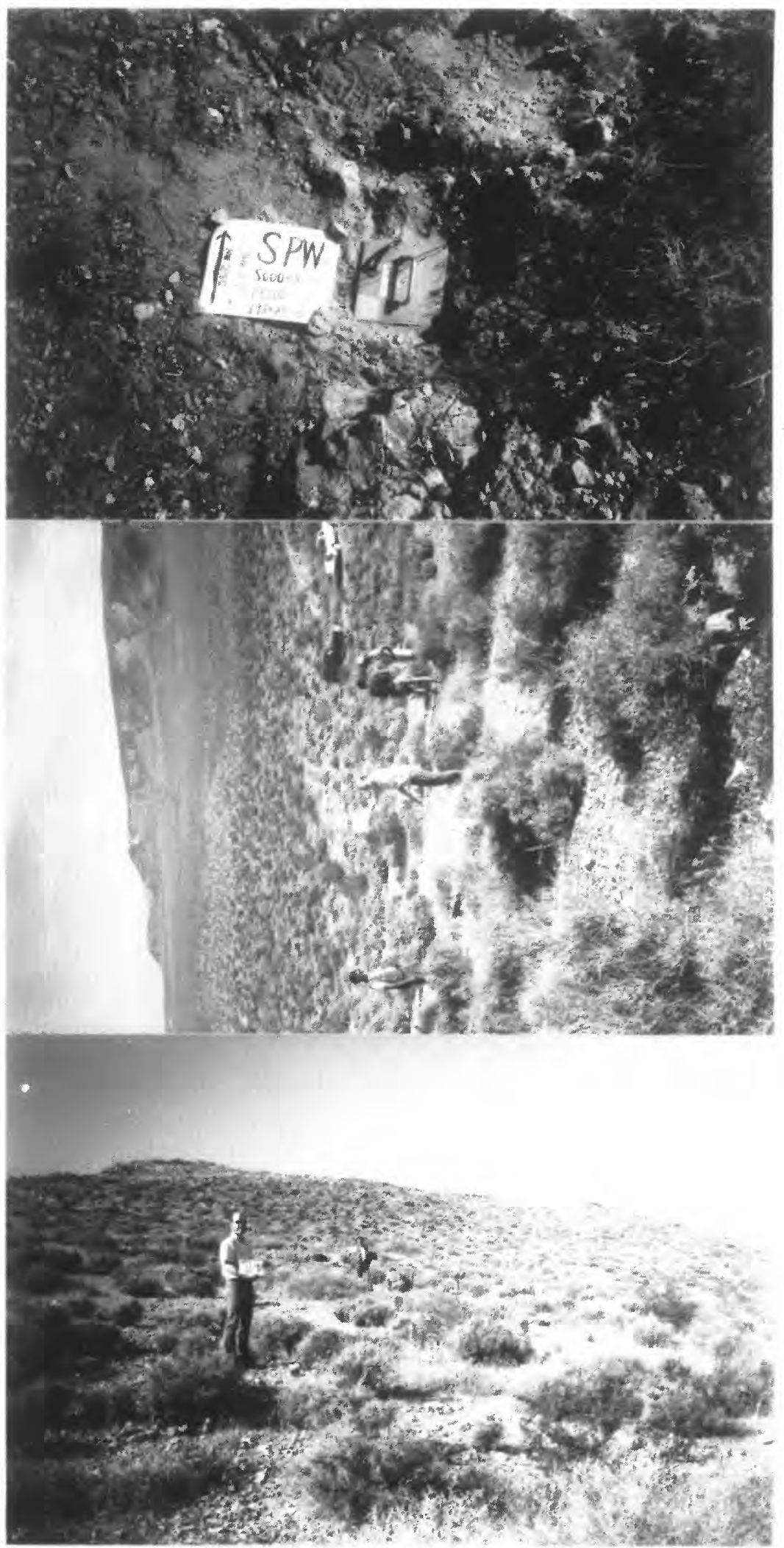

Instrumentation at site.

View to the north overlooking Rock Valley towards Skull Mt. The vehicles are parked at the backed side of the circle mentioned in site directions.

View to the south up to the top of the hill. The instrument is located where the person is crouching. 

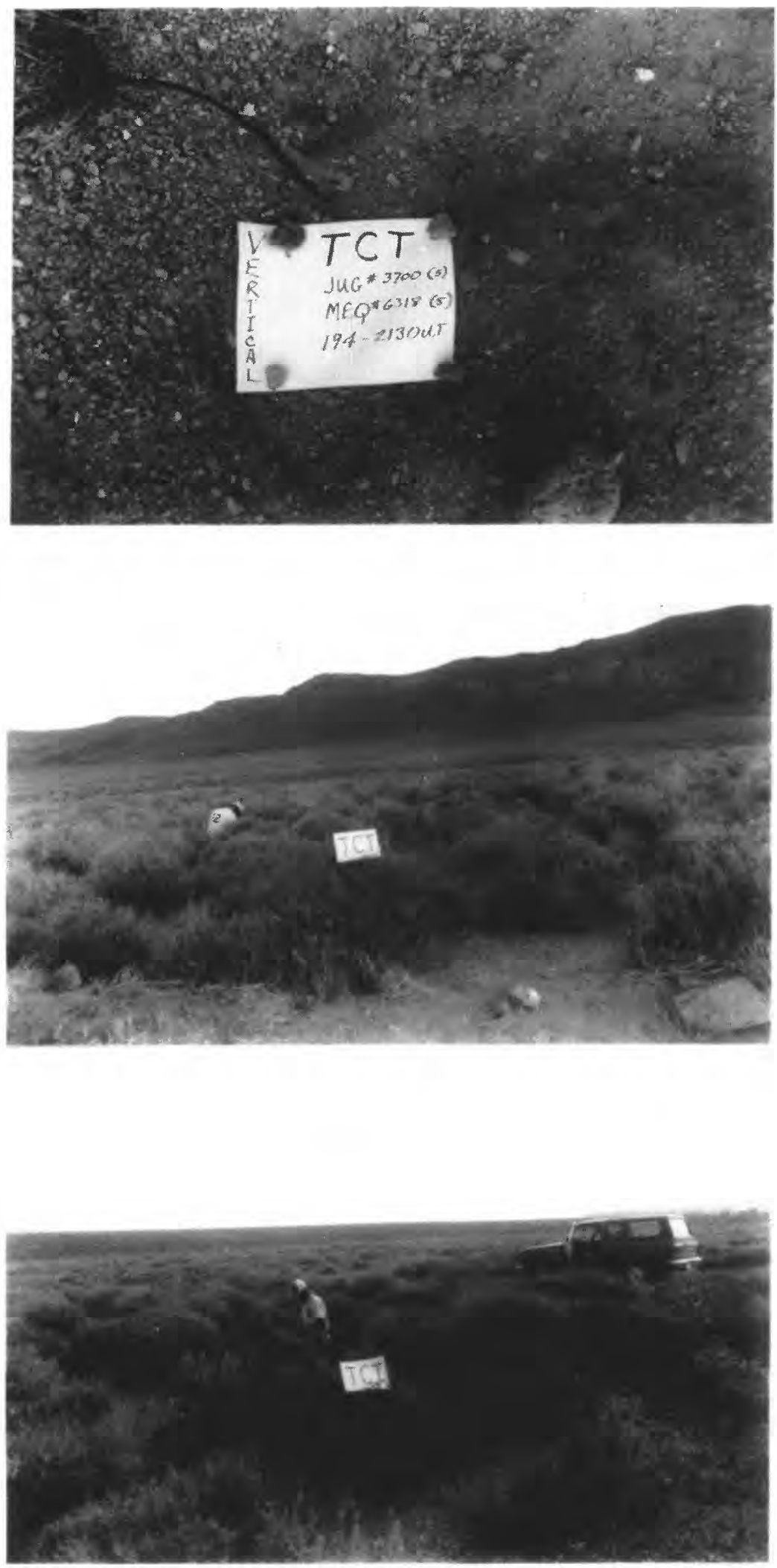

Instrumentation at site.

View to the east-southeast of the northwestern flank of Skull Mtn. The seismometer is to the right of the person about 3 to 4 meters.

View to the west-southwest across Jackass Flats with the Training Center buildings on the right. The vehicle is at the edge of the circle mentioned in the site directions. 


\section{Station: TOW}

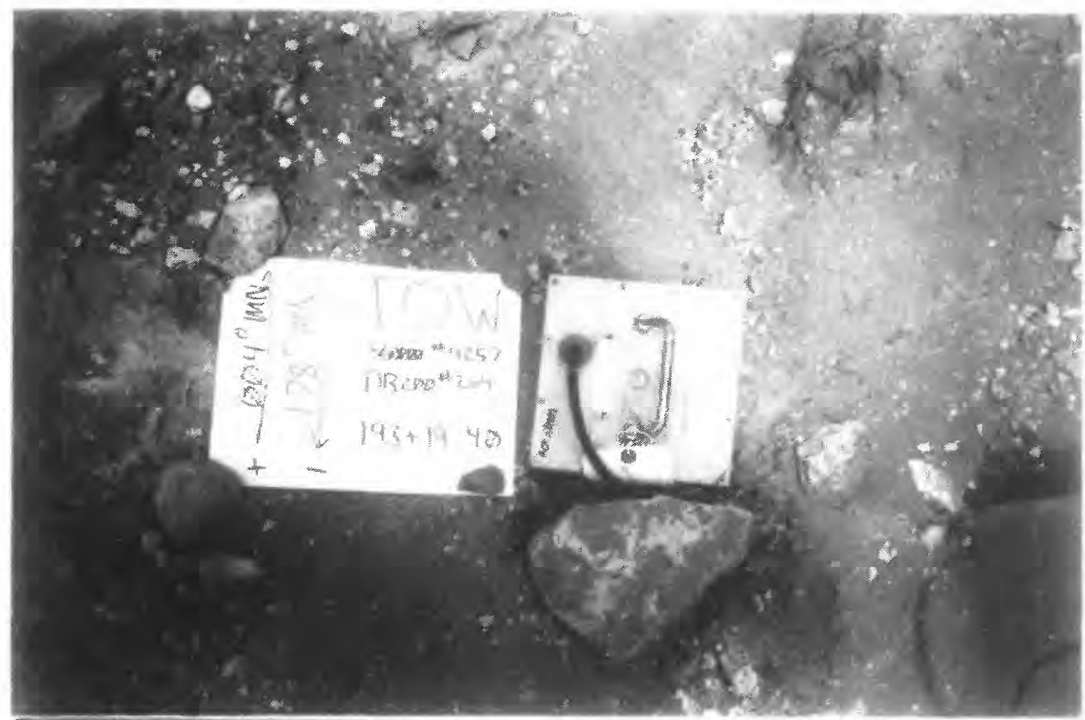

Instrumentation at site. This site is being prepared for a permanent digital installation.

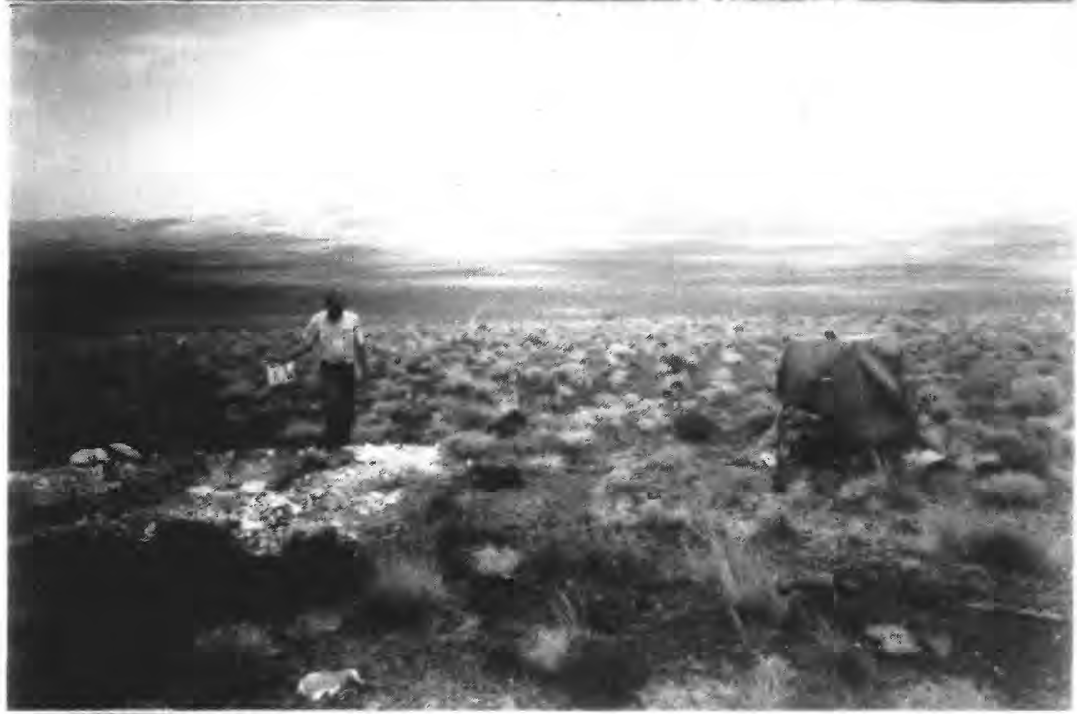

View to the north across western Jackass Flats to Calico Hills. The rectangular boxes are the future vaults for the permanent digital installation.

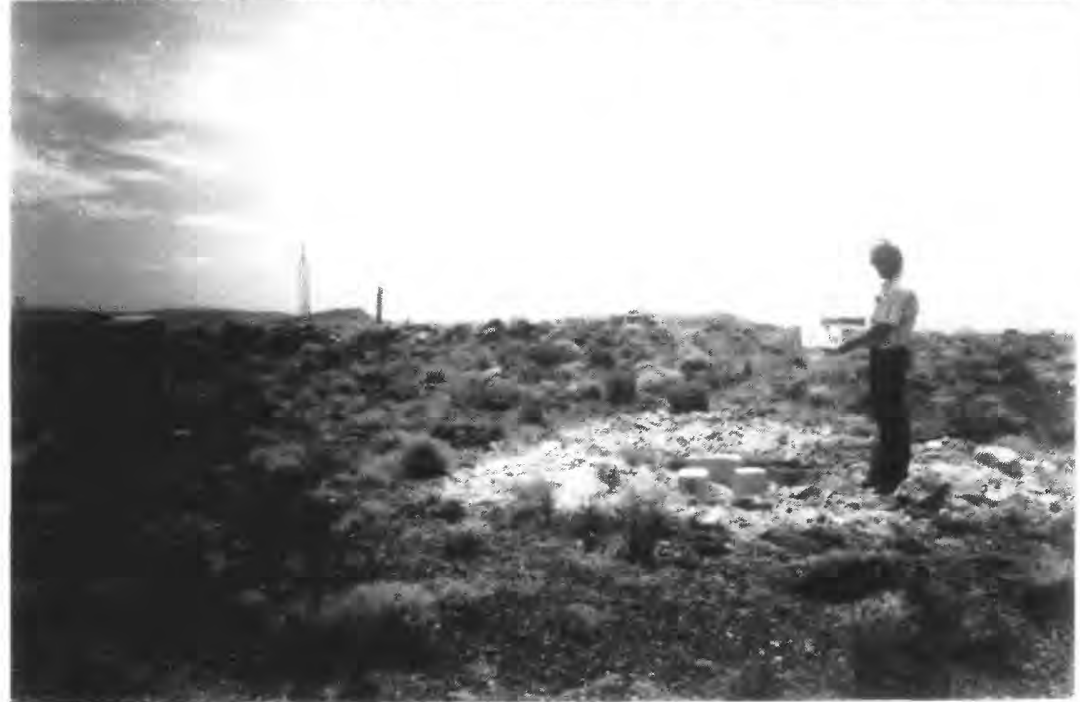

View to the south-southeast over the top of this hill. In the background to the right of the tower, is Little Skull Mtn. and, to the left, is Skull Mtn. 


\section{Station: TPP}

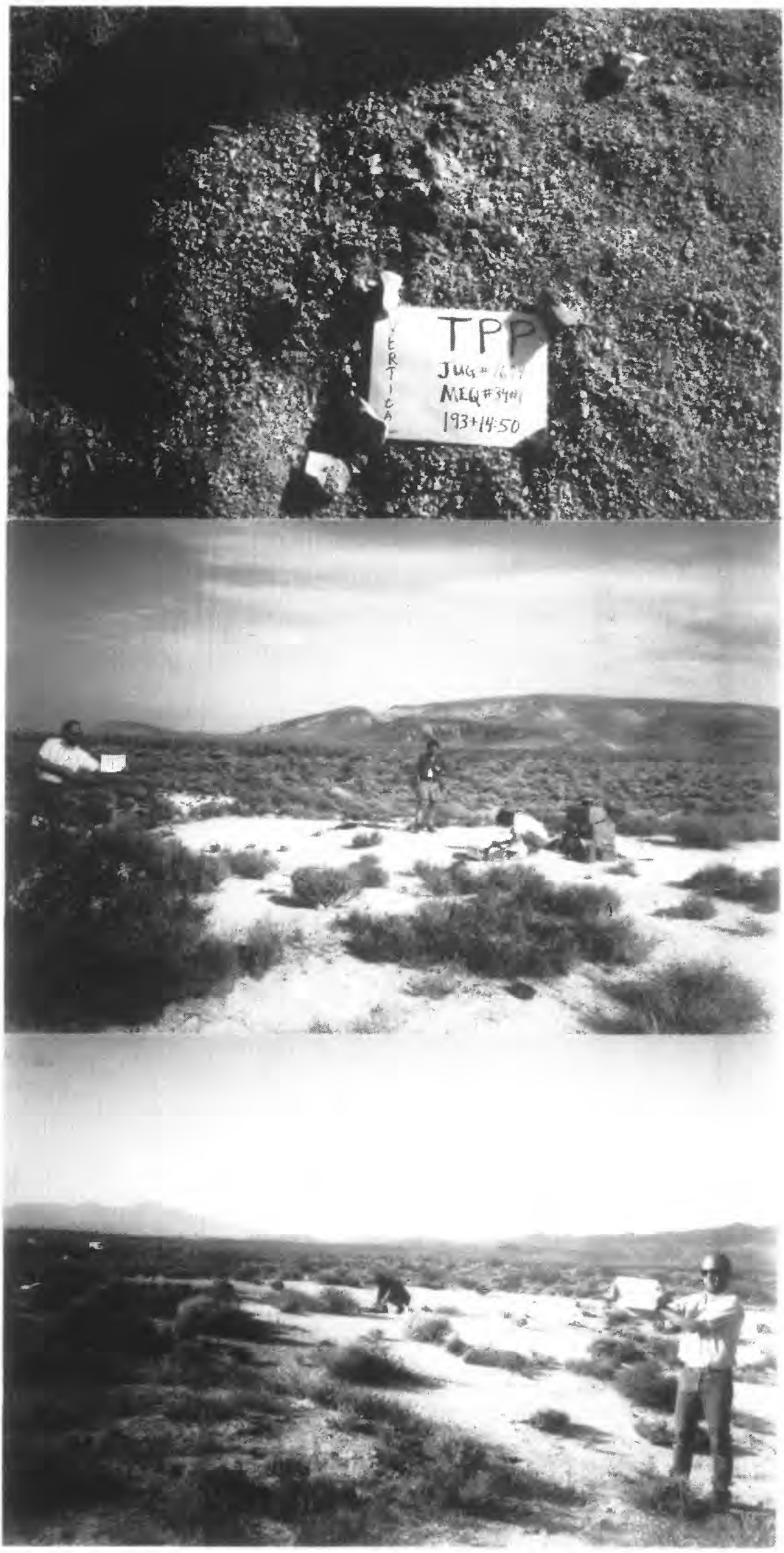

Instrumentation at site.

View to the west of Skull Mountain (background; center and right) and Little Skull Mountain (background; left).

View to the south-southeast back towards the vehicles parked near the dry stream bed mentioned in the site directions. 


\section{Station: TWR}

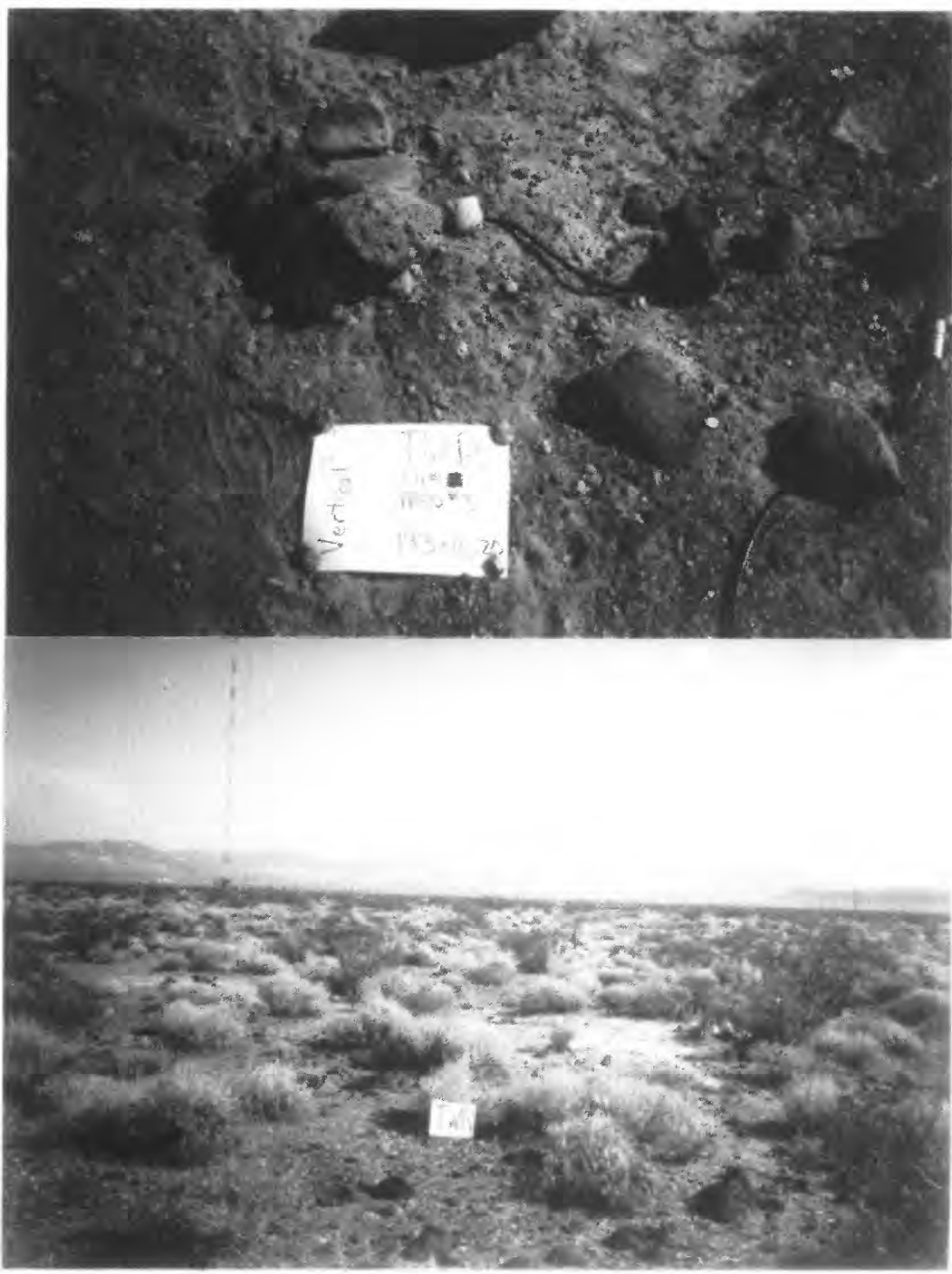

Instrumentation at site.

View to the north-northwest of Bren Tower, the domed structures of Test Cell C behind the tower, Calico Hills (background; far left), and Shoshone Mtn. beyond.

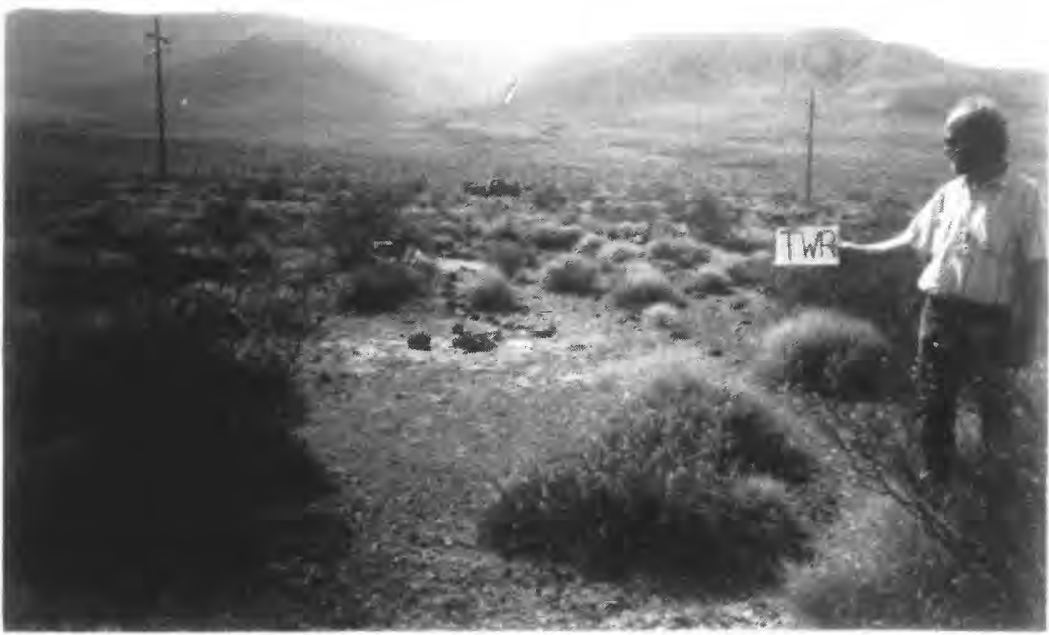

View to the east-souhteast of the southwestern flank of Skull Mountain. 


\section{Appendix E}

\section{Examples of Digital Waveforms}

From Two Events:

(190) 08-JUL-1992 04:34

(193) 11-JUL-1992 04:09 


\section{Seconds}

$\begin{array}{llllllllllllllll}0 & 1 & 2 & 3 & 4 & 5 & 6 & 7 & 8 & 9 & 10 & 11 & 12 & 13 & 14 & 15\end{array}$

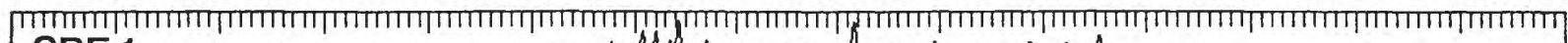

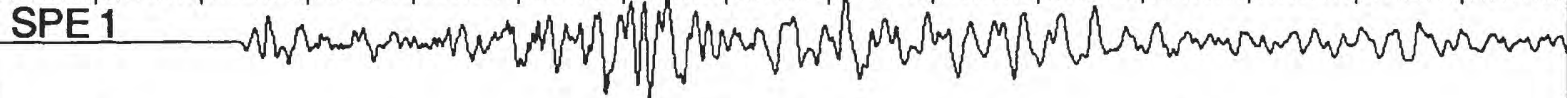

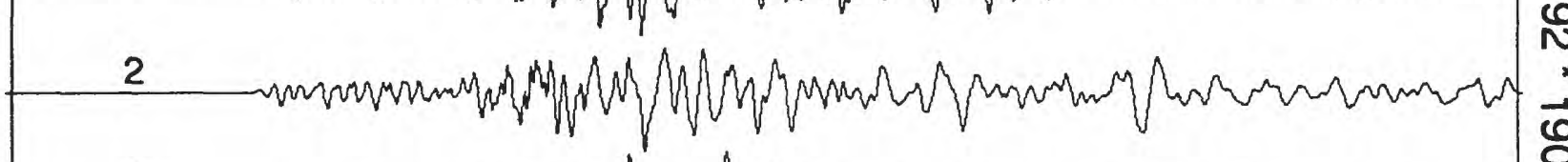

3

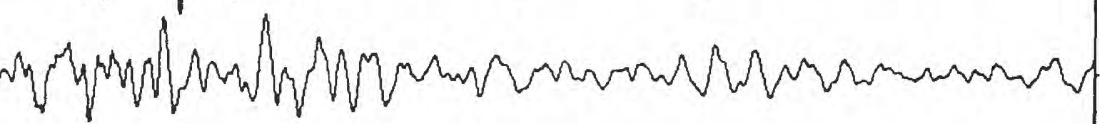

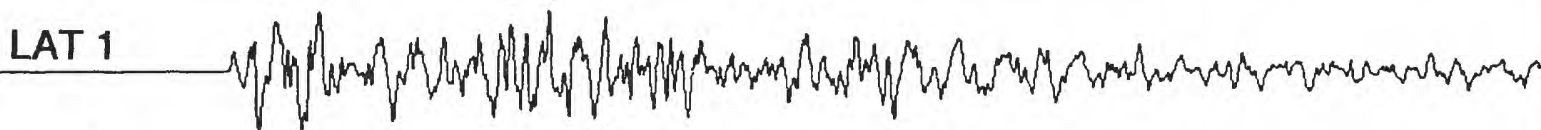
2

\section{LSD 1}

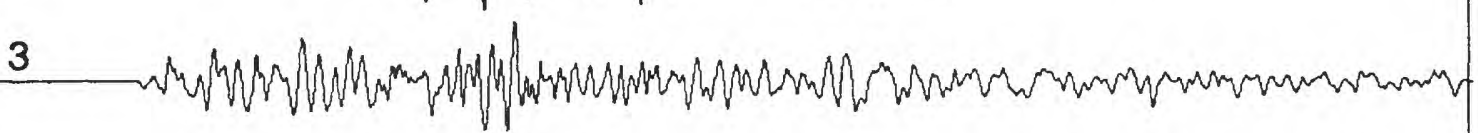

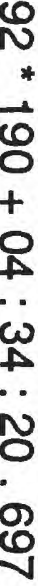

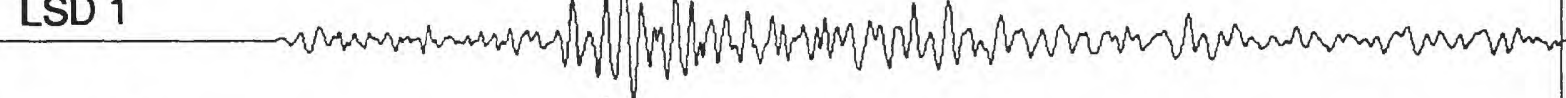
2 (n) 3

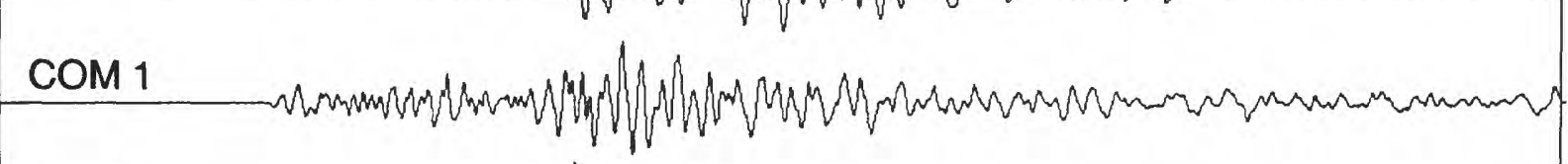
2
TOW 1
3
2
3 2
TOW 1
3
2
3 CAL 1

2

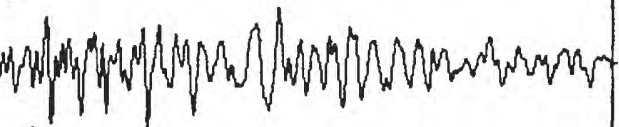

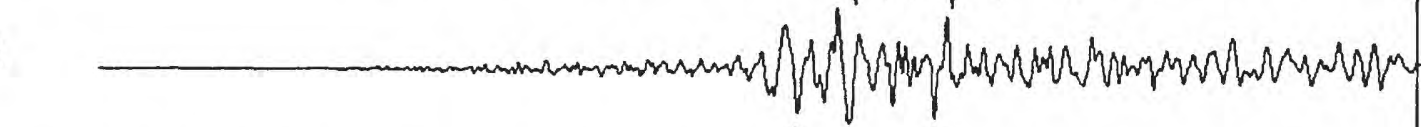
3

لس 


\section{Seconds}

$\begin{array}{llllllllllllllll}0 & 1 & 2 & 3 & 4 & 5 & 6 & 7 & 8 & 9 & 10 & 11 & 12 & 13 & 14 & 15\end{array}$

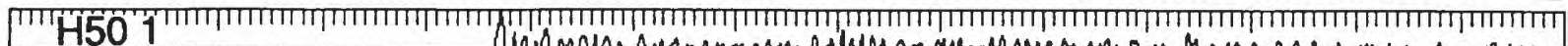

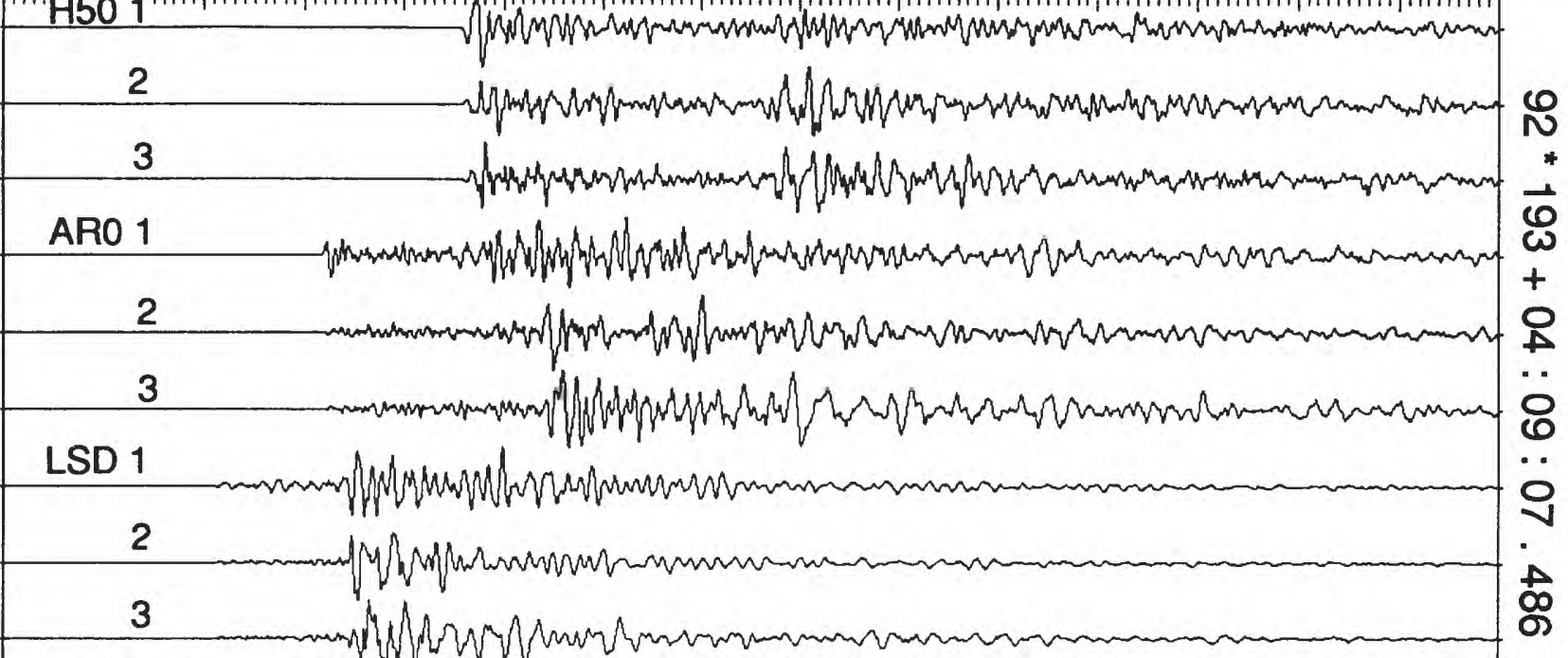

LAT 1 M.Nh

\begin{tabular}{|r|}
\hline LAT 1 \\
\hline 2 \\
\hline 3 \\
\hline COM 1
\end{tabular}

COM 1

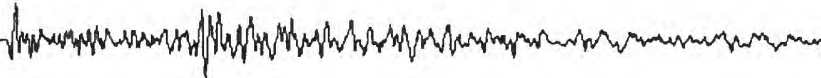

2

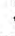

CLO 1

2

3

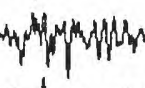

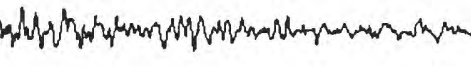

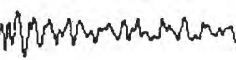

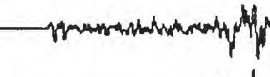

winumint

revingm

anderst

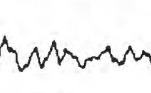

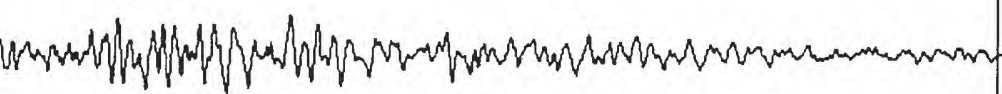

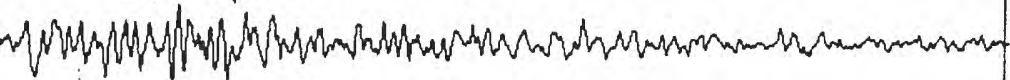

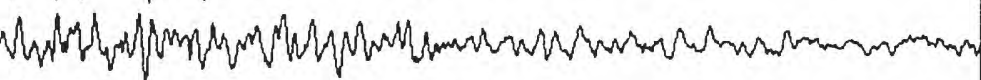

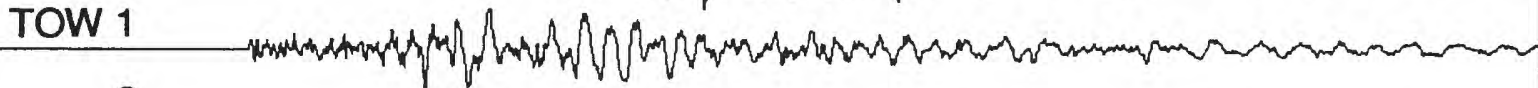
2

3

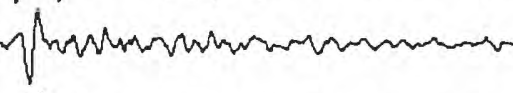

\begin{tabular}{l} 
SPE 1 \\
2 \\
\hline 3 \\
CAL 1 \\
2 \\
3
\end{tabular} Mhophown Mun

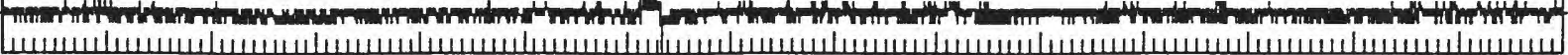




\section{Appendix F \\ Examples of Analog Records from the MEQ800 Instruments}

From Two Events:

(190) 08-JUL-1992 04:34

(193) 11-JUL-1992 04:09 

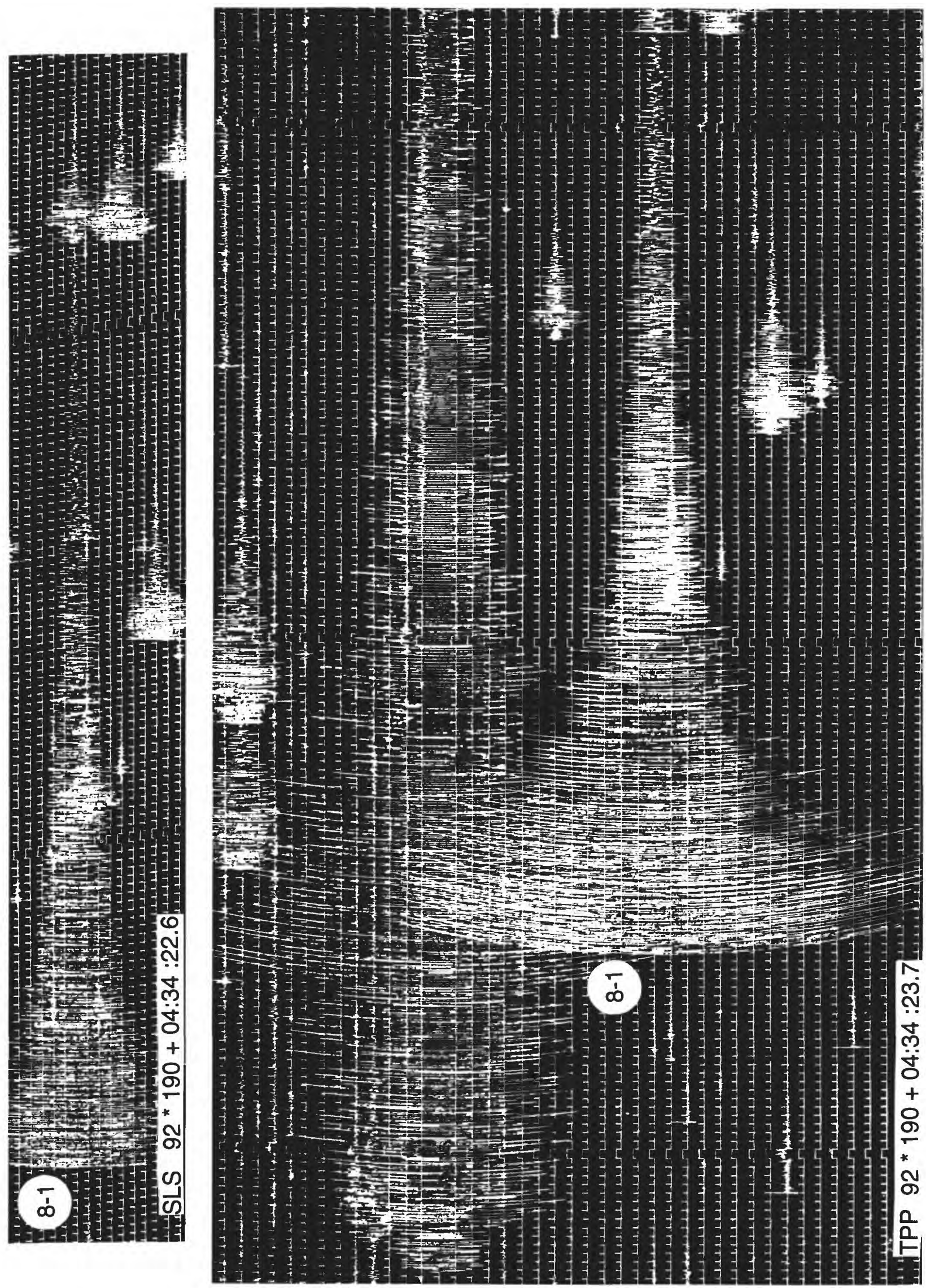

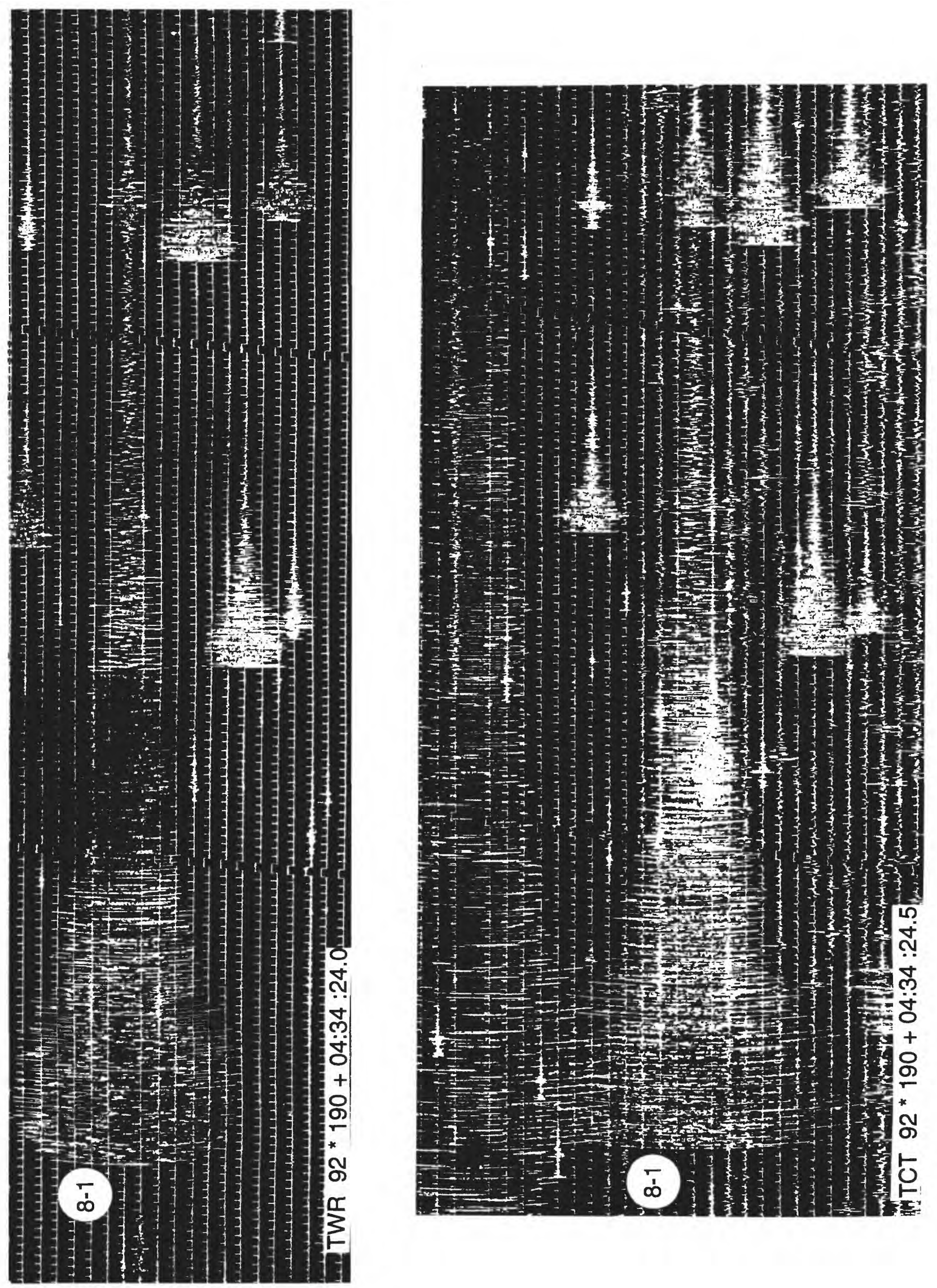

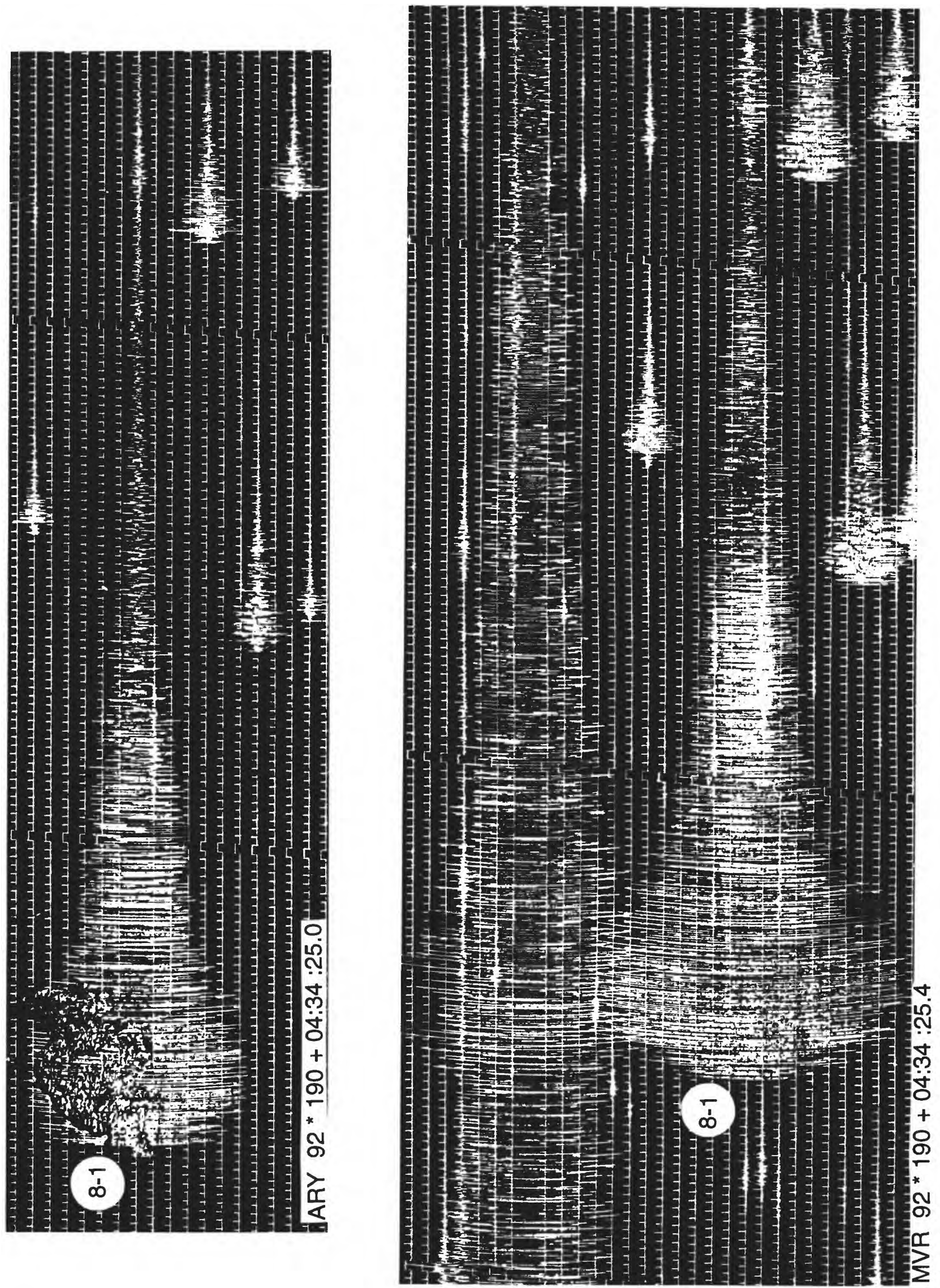

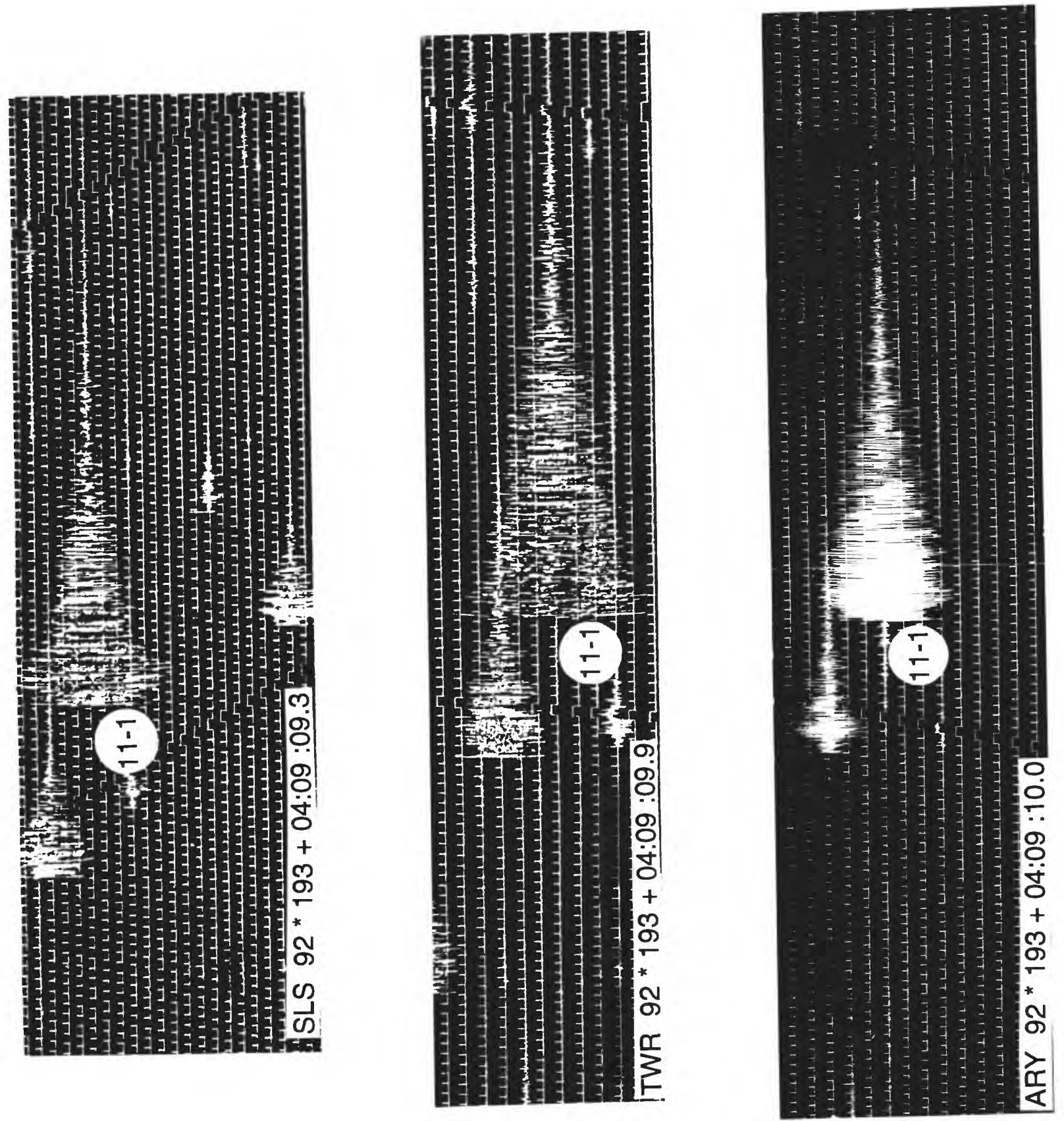

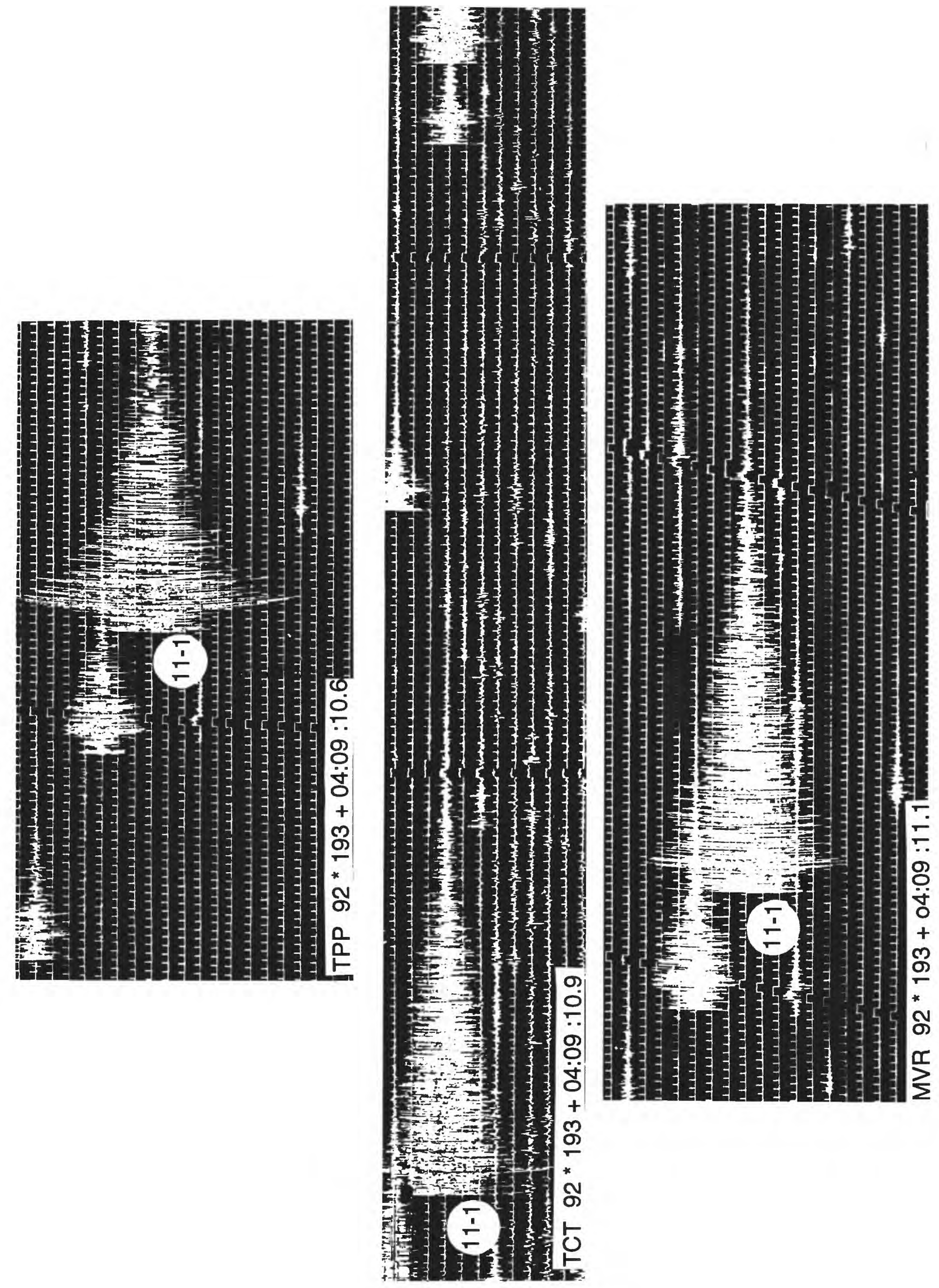